\title{
Windows of Repression: Using COVID-19 Policies against Political Dissidents?*
}

\author{
Joan Barceló ${ }^{1}$, Robert Kubinec ${ }^{2}$, Cindy Cheng $^{3}$, Tiril \\ Høye Rahn ${ }^{4}$, Luca Messerschmidt ${ }^{5}$
}

What explains the great variation in the adoption, timing, and duration of government policies made in response to the COVID-19 pandemic? In this paper, we explore whether government incentives to repress domestic dissidents influence their responses to the COVID-19 pandemic. We argue that containment policies are observationally equivalent to those that abusive governments would use to limit domestic dissent - i.e., policies that restrict citizen's freedom of movement. This creates an opportunity for abusive governments to engage in repressive behavior without countervailing pressure from citizens and the international community. Following this logic, we expect abusive governments to be more likely to adopt restrictive policies, adopt them earlier in the course of the pandemic, and take longer to relax restrictions. Empirically, we find that governments that have recently engaged in state violence against civilians or abused citizens' human rights were about 10 percent more likely to enact lockdown and curfew policies, and these policies were implemented approximately 48 days earlier in the course of the pandemic and kept in place for approximately 23 more days than less repressive countries. Overall, our results advance our understanding of how the repressiveness of state institutions can shape policy responses to a global health crisis.

\footnotetext{
${ }^{1}$ Assistant Professor, New York University - Abu Dhabi; joan.barcelo@nyu.edu. Corresponding author. ${ }^{2}$ Assistant Professor, New York University - Abu Dhabi; rmk7@nyu.edu. 3 Post-doctoral researcher, Hochschule für Politik at the Technical University of Munich (TUM) and the TUM School of Governance; cindy.cheng@hfp.tum.de. ${ }^{4}$ Student, New York University - Abu Dhabi; tiril.rahn@nyu.edu. ${ }^{5}$ Doctoral student, Hochschule für Politik at the Technical University of Munich (TUM) and the TUM School of Governance; luca.messerschmidt@hfp.tum.de.

*Authors ordered by contribution. For constructive criticisms on a previous draft, we are grateful to the guest-editors of the special issue, Gina Yannitell Reinhardt and Carmen Lutmar, and the feedback provided by Babak RezaeeDaryakenari, as well as the rest of the participants of the online workshop of this special issue. We deeply thank the CoronaNet coPIs, Allison Hartnett Spencer, Caress Schenk, Timothy Model, and Vanja Grujic, and the very large number of research assistants (RAs) who contributed to building the CoronaNet dataset. We very much thank Anelia Petrova, Keshana Ratnasingham, Natalia Filkina-Spreizer, Saif Khan, Annika Kaiser, Danny Downes, Sonja Muller, Stella Kim, Sarah Edmonds, Klea Vogli, Linlin Chen, Mayisa Nasirova, Janice Klaiber, Joshua Diversi, Katrin Hermann, Emily Westropp, Anoushka Thakre, Lionel Illert, Anke Horn, Isabel Conti, Isak Jones, Cootje Linssen, Konstanze Schönfeld, Bruno Ciccarini, Clara Wang, Henning Richter, and Jack Kubinec for their contributions, including cleaning, validation, project management, and visualization. We also gratefully acknowledge funding support from the TUM Chair of International Relations, the Hochschule fur Politik at the Technical University of Munich (TUM), New York University Abu Dhabi (Covid-19 Facilitator Research Grant) and the Leibniz Research Alliance Group 'Crises in a Globalised World'. This project has also received funding from the European Union's Horizon 2020 research and innovation programme under grant agreement No 101016233. Technical infrastructure support has been generously provided by Overton, Slack Technologies, and RStudio. The funders had no role in study design, data collection, analysis, or interpretation, nor in the decision to publish or in the preparation of the manuscript.
} 


\section{Windows of Repression: Using COVID-19 Policies against Political Dissidents?}

May 18, 2021

What explains the great variation in the adoption, timing, and duration of government policies made in response to the COVID-19 pandemic? In this paper, we explore whether government incentives to repress domestic dissidents influence their responses to the COVID-19 pandemic. We argue that containment policies are observationally equivalent to those that abusive governments would use to limit domestic dissent i.e., policies that restrict citizen's freedom of movement. This creates an opportunity for abusive governments to engage in repressive behavior without countervailing pressure from citizens and the international community. Following this logic, we expect abusive governments to be more likely to adopt restrictive policies, adopt them earlier in the course of the pandemic, and take longer to relax restrictions. Empirically, we find that governments that have recently engaged in state violence against civilians or abused citizens' human rights were about 10 percent more likely to enact lockdown and curfew policies, and these policies were implemented approximately 48 days earlier in the course of the pandemic and kept in place for approximately 23 more days than less repressive countries. Overall, our results advance our understanding of how the repressiveness of state institutions can shape policy responses to a global health crisis.

Keywords: State Repression, Civil Liberties, Health Policy, Disaster politics, Pandemic, COVID-19

Word count: 9,930 


\section{Introduction}

Emergency powers should not be a weapon governments can wield to quash dissent, control the population, and even perpetuate their time in power

- Michelle Bachelet, UN High Commissioner for Human Rights, April 27, 2020.

Governments around the world have adopted a variety of policies to limit the spread of the COVID-19 virus, many of which restrict citizens' rights and civil liberties (e.g. curfews, lockdowns). Though many countries have adopted restrictive policies to prevent the spread of the virus, they have made very different decisions in terms of how fast, how long and how strongly they implement them. By late April 2020 in the Philippines for example, over 120,000 people had been cited for quarantine violations and over 30,000 had been arrested over COVID-19 related breaches (Aspinwall, 2020). Instead of issuing citations to alleged violators, the Philippine police said it would arrest them immediately (Aspinwall, 2020). In Peru, President Martín Vizcarra announced one of the earliest COVID-19 lockdowns in Latin America on 16 March, mobilizing the army and police to enforce the stay-at-home order (The Guardian, May 2020). In contrast, far from enforcing a strict lockdown, the Swedish government, as well as other Scandinavian governments, allowed the vast majority of their populations to engage in voluntary social distancing (Savage, 2020). What explains the great variation in the adoption, timing and duration of policies made in response to the COVID-19 pandemic?

In this paper, we investigate whether a given government's pre-existing incentives for repression influences not only its decision to adopt restrictive policies writ large, but also the timing and subsequent duration of such policies when they are adopted. When facing domestic challengers, governments can either give in or repress dissidents. When governments decide to repress, they often choose collective repression methods if they have limited resources to implement targeted repression or want to signal state strength (Rozenas, 2020). However, even when states have incentives to collectively repress domestic challengers, 
international pressure acts as an important check to such behaviour. By calling attention to abusive state behaviors, external actors can increase the costs of repression and consequently, reduce the likelihood and severity of state-sponsored violence against civilians. Critically, however, external actors are only able to exert such pressure if they can observe the repressive actions of other states.

We argue that the global COVID-19 pandemic has created a scenario that impairs the international community and citizens' capacity to exert pressure on states to limit violent actions against civilians. Policies implemented to fight against the spread of the disease are observationally equivalent - or sufficiently observationally-similar to be distinguished only with great uncertainty - to policies commonly used to fight domestic dissent, including curfew and lockdown policies. This observational equivalence or similarity limits the capacity of the international community and citizens to exert pressure over repressive regimes. Hence, governments that have underlying incentives to oppress their citizens can take advantage of the global health crisis to strengthen repressive measures to control domestic dissidents without bearing the costs of greater international and domestic pressure.

Following this logic, we hypothesize three connected processes. First, in the wake of the global pandemic, governments with a history of repressing citizens are more likely to order restrictive preventive measures at all compared to governments that do not. By the same token, repressive governments also have greater incentives to embrace restrictive policies earlier because such policies not only allow them to achieve public health objectives, but also allow them to respond to domestic dissent. And, finally, governments with a history of repressing citizens are also more likely to impose these policies for longer periods compared to governments that do not.

To evaluate our hypotheses, we make use of the CoronaNet Government Response Dataset (CoronaNet) with data collected until August 31, 2020 (Cheng, Barceló, Hartnett, Kubinec and Messerschmidt, 2020). The CoronaNet Project is a large hand-coded dataset of more than 60,000 separate policy announcements made in reaction to COVID-19, includ- 
ing lockdowns and curfews, across more than 195 countries. We complement this dataset with two distinct sources of data on state repressive behavior. First, we employ geo-located information on violence against civilians reported in the Armed Conflict Location and Event Dataset (ACLED) before the COVID-19 outbreak (Raleigh, Linke, Hegre and Karlsen, 2010). Second, we merge our data with the Latent Human Rights Protection Scores, which uses a dynamic item response model to aggregate a bundle of hard-to-observe repressive indicators (e.g., torture, ill-treatment, imprisonment, violence) (e.g., Fariss, Kenwick and Reuning, 2020). These three data sources are further supplemented with historical data of the registered number of reported COVID-19 cases and deaths from the European Center for Disease Prevention and Control (ECDC), as well as a standard set of political, economic, and health factors.

To preview our results, consistent with our expectations, and based on a variety of statistical models and model specifications, we find that abusive governments are substantially more likely-between 10 and 15 percentage increase-to restrict citizens' freedom of movement through stay-at-home orders compared to non-abusive ones. Furthermore, such governments are also more likely to implement such policies earlier in the pandemic by approximately 48 days and to keep them in place by an additional 23 days compared to governments without such track records.

Our results have implications for understanding how the repressiveness of state institutions shapes policy responses to a global health crisis, which speaks to several strands of literature. First, it builds on the rich literature studying the behavioral and institutional causes and consequences of various forms of political violence, including wartime violence, terrorist attacks, rioting, and state repression (Balcells and Stanton, 2020). In a recent contribution, Aksoy, Menger and Tavits (2020) specifically evaluate the political consequences of curfews in Turkey, showing that curfews increase support by the majority group for the ruling party, while having the opposite effect on the minority group. Closer to this paper, Grasse, Pavlik and Matfess (2020) show that African countries have intensified their repres- 
sive campaigns after imposing lockdowns. This paper complements this work by arguing that the COVID-19 public health emergency has opened a window of opportunity for governments to engage in repressive behaviour without countervailing pressure from citizens and the international community. Additionally, our empirical evidence showing that abusive governments are more likely adopt stay-at-home orders is fully consistent with Grasse et al.'s (2020) results showing that lockdowns, once adopted, serve to intensify state violence in areas of dissent.

Second, it speaks to the literature on the dynamics of political violence in the context of natural disasters. Some work considers when and how droughts, floodings, earthquakes, fires, and other disasters, impact political violence with no clear-cut consensus (e.g., Koubi, 2019; Lehrs, this issue). Other work on disasters has also looked at the effect of exposure to disasters on violence with evidence showing that disasters reduces conflict in the short-term (Haer and Rezaee Daryakenar, this issue), and increase the chances of rebel groups to seek negotiations with the government (Nemeth and Lai, this issue). Similarly, Koehnlein and Kore (this issue) show that COVID-19 prevalence increases the likelihood of attacks against civilians by pro-government non-state actors. We specifically contribute to this literature by showing that states' response to a global health disaster depends on their pre-existing incentives to repress domestic dissent. We further point out that this might be particularly important for disasters that call for policies that are observationally equivalent to policies commonly used to deter domestic dissent such as lockdowns and curfews. .

Finally, this paper also contributes to the recent literature of the political and social causes and consequences of the COVID-19 pandemic. Social scientists have, thus far, provided a wealth of research on the social and political correlates of policy responses to the COVID-19. Some work has focused on explaining what has driven citizens' reaction to the pandemic and the associated policies, including work on partisanship (e.g., Kubinec, Carvalho, Cheng, Barceló, Hartnett, Messerschmidt, Duba and Cottrell, 2020), political polarization (e.g., Allcott, Boxell, Conway, Gentzkow, Thaler and Yang, 2020), institutional 
trust (Goldstein and Wiedemann, 2020), institutional messaging (e.g., Arriola and Grossman, 2020), and social norms (e.g., Barceló and Sheen, 2020). Other scholars have tried to uncover the cross-national determinants on the cross-national policy response to the pandemic, including studies on the role of political regimes (e.g., Frey, Chen and Presidente, 2020), federal institutions (Buthe, Barceló, Cheng, Ganga, Messerschmidt, Hartnett and Kubinec, 2020), and state capacity (e.g., Frey, Chen and Presidente, 2020). Our study contributes to this emerging literature by emphasizing the critical role of governments' incentives to repress and, more specifically, by demonstrating that a recent history of political violence and a lack of human rights protection is associated with cross-country variation in government responses to the COVID-19 pandemic.

\section{Repression and Dissent Amidst a Global Pandemic}

Dissent takes place when non-state actors collectively genuinely do, or threaten to, impose costs on their government to encourage a change in the status quo (Ritter, Conrad et al., 2016). Violent and non-violent acts, such as strikes, boycotts, riots, and non-violent protests, taken by dissenters can endanger the government's hold on power. One way in which states can respond to these challenges to its power include repressing the dissidents (Ritter, 2014; Ritter, Conrad et al., 2016).

State repression "involves the actual or threatened use of physical sanctions against an individual or organization, within the territorial jurisdiction of the state, for the purpose of imposing a cost on the target as well as deterring specific activities and/or beliefs perceived to be challenging to government personnel, practices or institutions" (Davenport 2007, drawing on Goldstein 1978, xxvii). Repression can be targeted toward individuals or particular groups (e.g., arrests) or indiscriminately applied toward entire collectives (e.g., curfews or lockdowns). Lockdowns and curfews, which are imposed on everyone within a geographical area and, thus, apply equally to political dissenters as well as apolitical civilians, are one 
common form for indiscriminate repression (Brass, 2006; Aksoy, Menger and Tavits, 2020). Though most have non-violent enforcement mechanisms (e.g. fines), in some cases, violations can be punished, imprisonment and, in extreme cases, even death (Brass, 2006).

Why do governments choose to repress dissenters as opposed to give in to their demands? Scholarly consensus suggests authorities repress their citizens to control dissent (e.g., Davenport, 2007; Nordås and Davenport, 2013; Ritter, Conrad et al., 2016). States are more likely to use collective repression, as opposed to relent to dissenters' demands, when the state's capacity to survive a wide-spread rebellion is weak, when cross-group polarization is strong, and when there are grievances across the entire society (Rozenas, 2020). Repression and dissent are, however, endogenous (Ritter, Conrad et al., 2016). Governments often respond to threats to its authority with repressive behavior. At the same time, state repression strongly raises the likelihood of dissent. That is, though governments engage in repressive behavior in the hopes that forceful action will deter further dissent, repression often provides incentives for the very behavior governments intend to deter (Hill Jr and Jones, 2014; Siegel, 2011). ${ }^{1}$ Similarly with regards to collective repression in particular, though the existing literature points to ample evidence of its widespread use, the same literature also suggests that violent collective repression is at best ineffective and at worst counter-productive when responding to dissident challenges (Kalyvas, 2006; Valentino, 2014).

The literature identifies two major arguments as to why states still use collective repression despite potential backfire effects: state capacity and signalling. With regards to state capacity, states often do not have the resources to apply targeted repression and therefore must use low-cost collective repressive measures. To repress individual citizens, the state must obtain costly intelligence about their behaviors. As such, only states that have the resources to control, monitor, and collect taxes from the population will have the capacity to selectively crack down on domestic dissidents. Even states with high capacity may choose to engage in relatively low-cost collective repression. Indeed, Hitler was quoted

\footnotetext{
${ }^{1}$ However, see Lyall (2009) or Barceló (2018) for null or inconsistent findings for the backfire theory of state repression.
} 
as saying, "I shall spread terror through the surprising application of all means. Why should I deal otherwise with all my political opponents? These so-called atrocities save me hundreds of thousands of individual actions against protesters and discontents" (Hitler, quoted in Gurr $(1986,46-47))$. In general then, while states with low capacity cannot apply selective repression and must therefore rely on less efficient forms of collective repression (Kalyvas, 2006; Gregory, Schröder and Sonin, 2011), all states may plausibly choose collective repression over targeted repression because of its lower costs.

Second, states may also intentionally use collective repression as a signalling device. In an environment of incomplete information with repeated interaction, strategic actors have incentives to engage in a reputation-building strategy (Kreps and Wilson, 1982). By indiscriminately repressing more civilians, states send a strong signal of resolve that they will maintain the status quo. This unwavering message to enemies that policy concessions will not be granted allows them to build a domestic reputation of steadfastness (Acemoglu and Robinson, 2000; Walter, 2006). In these settings, even if the state has the capacity to selectively repress, it can choose not to. For instance, executors of state violence in El Salvador were instructed to indiscriminately repress the indigenous population even in the absence of evident disloyalty (Gould and Laura-Santiago (2008)).

While its theoretical logic is sound, the signaling argument is wanting on the grounds of empirical consistency. In many instances, states not only abstain from publicizing their repressive measures, but also attempt to obfuscate them (Gruffydd-Jones, 2019; Shadmehr and Bernhardt, 2015), particularly when applying large-scale indiscriminate repression. Abusive states may believe that the expected political benefit of repressing domestic challengers is positive only if it remains hidden to the international community (Afesorgbor, 2019). Indeed, repressive measures can be costly if they become publicly reported as they could damage a country's international reputation or legitimacy and lead to significant consequences in the form of breaking clauses in preferential trade agreements (Hafner-Burton and Tsutsui, 2005), economic sanctions (Afesorgbor, 2019), and even military interventions (Conley and 
Hazlett, 2019).

International pressure can directly reduce the likelihood and severity of state repression. By calling attention to repressive state behaviors, external actors such as international organizations (DeMeritt, 2012), other states (Terman and Voeten, 2018), human rights tribunals (Appel, 2018; Hillebrecht, 2014), international media (Krain, 2012), and human rights NGOs (Krain, 2012; Murdie and Davis, 2012; Terman and Voeten, 2018) can pressure repressive governments to align with global norms and reduce their abusive behavior.

Beyond its direct influence on state repression, public criticism may trigger further external action that makes it costly for states to continue behaving repressively. This may work through several pathways. First, repressive states may be excluded from international treaties if systematic human rights abuses come to light. Some scholars demonstrate that adding human rights clauses to economic agreements effectively reduces state repression, especially among countries that depend on foreign aid (Donno and Neureiter, 2018; HafnerBurton, 2005). Second, foreign aid may be withdrawn as a result of state abuses. Lebovic and Voeten (2009) show that multilateral institutions (e.g., the World Bank) punish countries that violate human rights by reducing their allocated amount of foreign aid. Third, regardless of their actual effectiveness in preserving human rights (?Wood, 2008), stopping state repression constitutes one of the major explanations for imposing economic sanctions (Hufbauer, Schott, Elliott et al., 1990). At an extreme, public knowledge of ongoing largescale state violence may lead to foreign military intervention to end mass atrocities (Conley and Hazlett, 2019).

\section{The Global Pandemic Opens a Window of Repression}

External states and citizens are willing to sanction countries if they engage in repressive action (McLean and Roblyer, 2017). International pressure can deter or mitigate state repression against civilians through several mechanisms, including international treaties, aid, sanctions, and even foreign interventions to stop large-scale violence. While collective re- 
pression itself has relatively low operational costs compared to targeted repression and may additionally provide domestic signalling benefits to its users, external pressure may raise international reputational costs enough to overcome these perks. However, international pressure crucially depends on the ability of external actors to observe repressive state actions, and such actions can only be observed imperfectly through indirect sources. As such, since sanctions are costly, international actors only impose sanctions if both the degree of a government's domestic repression and certainty that the repression is unjustified is high.

In the past, sovereign states have commonly made use of stay-at-home orders, in the form of lockdowns or curfews, as an important collective repressive tool to quell politicallymotivated violence from domestic challengers (Brass, 2006). The government of Sri Lanka, for instance, has implemented several nation-wide curfews to reduce ethnic violence since 1983 (Pavey, 2008); the Indian national government has made use of curfews and lockdowns to tackle potential unrest in Kashmir (Graff, Galonnier et al., 2012), and the Egyptian government imposed a curfew during the 2011 uprising (Marfleet, 2016), just to mention a few examples. Across most cases, stay-at-home orders have had significant implications for the safety and well-being of those who live within the bounded areas, including food shortages, limited access to health and education, and even severe violations of the right to physical integrity and life (Brass, 2006).

Whereas curfews and lockdowns typically characterize repressive action by abusive governments against civilians in ordinary times; these policies have become essential components of most governments' policy toolbox amidst the COVID-19 global pandemic (Flaxman, Mishra, Gandy, Unwin, Mellan, Coupland, Whittaker, Zhu, Berah, Eaton et al., 2020). The majority of national governments have implemented large-scale public health and safety measures such as lockdowns and curfews in response to the spread of the COVID-19 (Cheng et al., 2020). Figure 1 documents the sudden spike in the stay-at-home orders around the world between mid-March and mid-April 2020, reaching a peak in the second week of April, 
Figure 1: Timeline of stay-at-home orders around the world

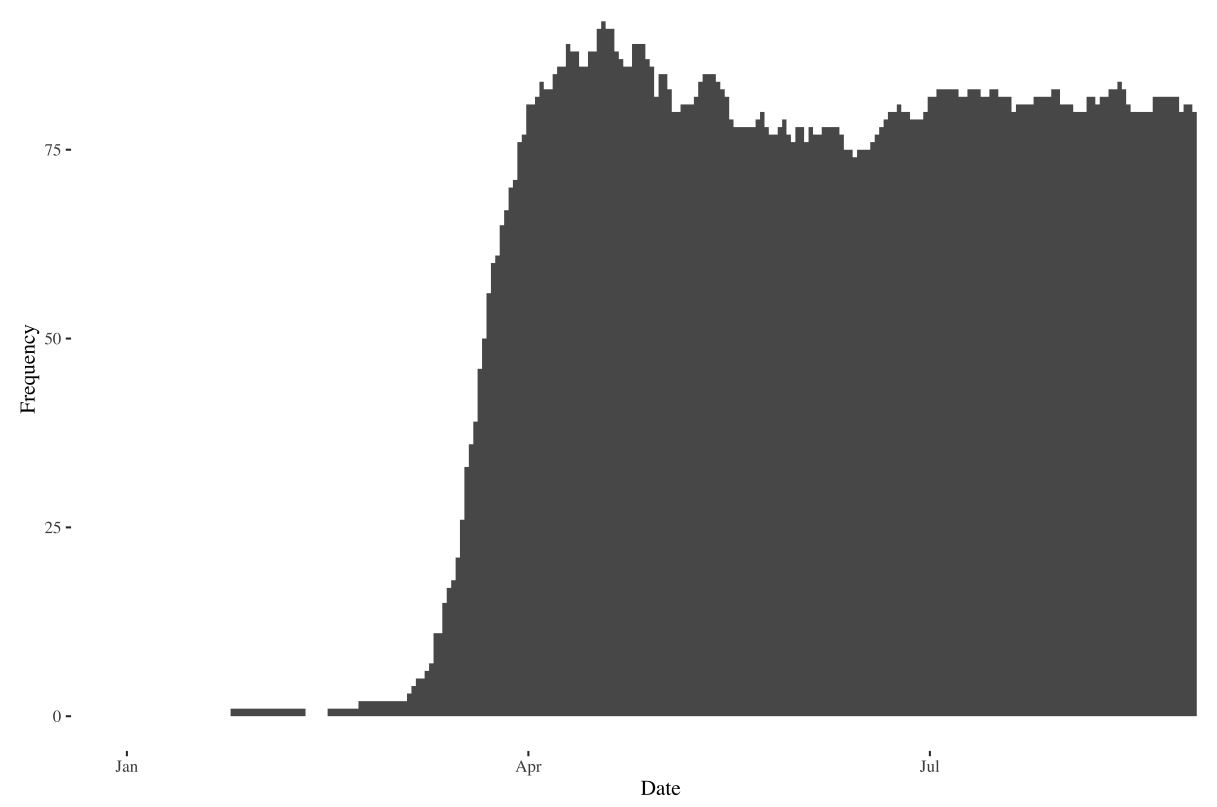

Note: The barplot reflects the frequency of a stay-at-home order in place in the sample (135 countries) and the time period (243 days) in the analysis.

and a gradual easing of restrictions from then on. ${ }^{2}$

In the wake of the COVID-19 pandemic however, distinguishing between measures taken to limit the spread of the virus and those to address dissent against the government has become difficult. Governments have contained the spread of the virus by adopting stay-at-home orders, internal border restrictions, restrictions of mass gatherings, which, in appearance, are often observationally equivalent to repressive policies adopted to fight domestic dissent. In this scenario, even if some countries employ these policies to repress rather than prevent the spread of the virus, citizens or external actors cannot intervene or exert pressure because they are ignorant of the true reason behind those policies.

In some instances, containment and repressive policies might be not completely observationally-equivalent, but are nevertheless so sufficiently similar that there is too po-

\footnotetext{
${ }^{2}$ The first stay-at-home order in the dataset goes back to the province of Jiangxi, China, on February 6. Before that date, stay-at-home orders had affected a few cities, counties, and districts in the provinces of Anhui, Hubei (including the city of Wuhan, the earliest epicenter of the pandemic), Liaoning, Jianxi, Shaanxi, Shandong, Sichuan, Zhejiang. However, Jiangxi provinces' stay-at-home order was the first time a stay-at-home order affected an entire first-level administrative unit in China.
} 
tential for error to object. Whereas external states and citizens are willing to sanction countries if they engage in repressive action, doing so is costly. Citizens may find it difficult to mobilize against governments if the repression measures are for an apparently legitimate public health purpose, which may have helped stall protest movements in Hong Kong and Algeria. ${ }^{3}$ Besides the obvious economic costs of sanctioning and intervening in foreign countries, in the context of the pandemic, international actors are particularly risk averse in interfering in domestic affairs given that a false step can send mixed signals about the efficacy of containment policies in general. Thus, they would be unlikely to raise objections, let alone intervene over a country's stay-at-home order if there is sufficient uncertainty about the true intentions of the government. Even if such policies were merely observationally similar, as opposed to observationally equivalent, international actors would still be impaired in their ability to constrain the use of such policies.

Governments with underlying incentives to oppress their citizens thus may find in the global pandemic a window of opportunity to strengthen their repressive measures to further control domestic dissent without bearing the costs of greater international or domestic pressure. Specifically, a public health crisis increases uncertainty about the reason for repression and permits abusive governments to repress without facing international pushback.

While we cannot directly observe the sincere intentions of specific governments, we test and evaluate three observable implications consistent with our logical argument. Due to the uncertainty about the reason for the adoption of restrictive policies, we first expect abusive governments to be, on average, more likely to adopt restrictive policies at any point in time compared to governments that have no record of state violence or a record of human rights respect and protection. This leads to our first hypothesis:

Hypothesis 1: Governments that abuse human rights or those with a recent history of violence against civilians are likely to impose restrictive measures earlier in the pandemic than

\footnotetext{
${ }^{3}$ See https://thediplomat.com/2020/04/hong-kongs-protests-amid-covid-19-a-dying-movement-or-ahalted-war/ for a discussion of Hong Kong's protest movement amid COVID-19.
} 
governments that protect human rights or have no recent history of violence against civilians.

Second, we also expect that abusive governments may readily embrace the imposition of restrictive policies more quickly than non-abusive governments, even controlling for public health drivers. Following this intuition, we hypothesize:

Hypothesis 2: Governments that abuse human rights or those with a recent history of violence against civilians are more likely to adopt restrictive measures than governments that protect human rights or have no recent history of violence against civilians.

In a scenario where repressive policies may receive little or no pushback, not only do abusive governments have incentives to impose more restrictions but they should also be more reluctant to lift restrictions once the pandemic wanes. This logic leads to our third empirical hypothesis:

Hypothesis 3: Governments that abuse human rights or those with a recent history of violence against civilians are more likely to impose restrictive measures for longer periods than governments that protect human rights or have no recent history of violence against civilians.

\section{Data}

Our main data source is the CoronaNet Government Response Dataset (CoronaNet) (Cheng et al., 2020). CoronaNet is an ongoing data collection project, which covers systematic information on the multitude of policy responses governments have taken to address the spread of the COVID-19 virus. At the time of writing, CoronaNet includes more than 60,000 separate policy announcements made in reaction to the COVID-19. For each policy 
announcement, CoronaNet collects information on the governmental initiator of a policy, the type of policy being implemented, its duration, the geographic and demographic targets of the policy, the compliance mechanism, and the way in which a policy is enforced, among other attributes. We choose to use CoronaNet over other existing datasets because it has greater coverage (over 190 countries), a rigorous and systematic data validation procedure, provides portable document formats with the information source, and fine-grained information about the initiator, target, and enforcement mechanism of the policy. However, we limit our analysis to the first wave of the pandemic as this is the time where all countries had to quickly react to an unexpected global crisis. As such, the time span of our analysis to August 31st because by this time, most countries experienced the first wave of the pandemic.

We measure the timing of implementation of stay-at-home orders, either in the form of a "Curfew" or a "Lockdown", for at least one first-level administrative unit in the country (i.e., state, region). To define terms, a curfew is implemented if there are "government policies that limit domestic freedom of movement to certain times of the day" and a lockdown is implemented if there are "government policies that force citizens to stay at home all the day except for essential activities". ${ }^{4}$ See Cheng et al. (2020) for further details on the definitions of policy types.

We complement the CoronaNet data with two datasets that separately capture governments' predisposition to repress domestic dissent. First, we use geo-located information on observed violence against civilians provided in near-real time from the Armed Conflict Location and Event Dataset (ACLED) before the COVID-19 outbreak (Raleigh et al., 2010). ACLED collects fine-grained data on the locations, dates, and actors of all reported political violence across most countries around the world. For our empirical analyses, we use the ACLED data on "violence against civilians", which is defined as "violent events where an organised armed group deliberately inflicts violence upon unarmed non-combatants" (ACLED).

\footnotetext{
${ }^{4}$ Note then, that curfews and lockdowns are different methods of restricting civilian movement and as such are mutually exclusive policies, i.e. countries that impose lockdowns cannot impose a curfew at the same time.
} 
By definition, the perpetrators of such acts can only be state forces and their affiliates such as rebels, militias, and external forces. We exclude from our measure of state repression any event in which the perpetrator of violence was not the state, e.g., rebel groups against unarmed civilians or civilians against civilians. ${ }^{5}$ Importantly for our coding strategy, we include any attempts at inflicting harm (e.g., beating, rape, mutilation) against civilians or forcibly disappearing (e.g., kidnapping) civilian actors. ${ }^{6}$ The main explanatory variables from ACLED in the models is the number of events involving violence against civilians per one million population in the country. ${ }^{7}$ The time window for counting the number of events is the entire 2019. However, none of our findings are sensitive to this time window (see the online Appendix D).

While ACLED provides fine-grained data on political violence around the globe, it comes with two major limitations as a measure of state repression. First, ACLED only records repressive events that are realized, publicly observed, and documented. That is, ACLED does not capture the uncertainty associated with count data of difficult-to-observe events. Hence, an accurate measure of a comprehensive repressive behavior is, following our own logic, complicated by the fact that governments have reasons to conceal these events from the international community. Second, while ACLED collects information from nearly every country in Africa, Asia, Latin America and the Caribbean, as well as Eastern Europe, countries from Western Europe, North America and Oceania are not available in the dataset. In total, our analysis includes 135 countries (see the online Appendix A for a list of countries, the online Appendix B for descriptive statistics). We evaluate the potential impact of this non-random missingness in the online Appendix F.

We further bolster our analysis with data from the Latent Human Rights Protection

\footnotetext{
${ }^{5}$ See the Online Appendix E for how sensitive our findings are when including all episodes of violence against civilians regardless of the perpetrating actor: the results remains substantively unaltered.

${ }^{6}$ The three subcategories of violence against civilians that are added to create our measure of violence are: "Sexual violence", "Attacks", and "Abduction/Forced Dissapreance".

${ }^{7}$ We use the number of events rather than the number of fatalities because the number of fatalities is associated not only with the governments' willingness to repress domestic dissent but also with their skilfulness at doing so.
} 
Scores (Version 4). These scores measure the physical integrity rights protection in each country-year by using a dynamic item response model that aggregates a bundle of hardto-observe repressive indicators (e.g., torture, ill-treatment, imprisonment, violence) in a summary score (Fariss, 2014; Fariss, Kenwick and Reuning, 2020; Reuning, Kenwick and Fariss, 2019). Fariss et al. create a single latent measure of repression for countries in a given year drawing on 16 different sources of human rights information, including the CIRI Human Rights Data Project (Cingranelli and Richards, 1999), the Ill-Treatment and Torture (ITT) Country-Year Data (Conrad, Haglund and Moore, 2013), the Political Terror Scale (Gibney, Cornett, Wood, Haschke, Arnon, Pisanò and Barrett, 2019), and the UCDP One-sided Violence Dataset, 1989-2015 (e.g., Eck and Hultman, 2007), among others.

The Latent Human Rights Protection Scores has major benefits that complement our above-mentioned ACLED indicator of actual violence against civilians and over alternative approaches. First, it assesses states based on their aggregate level of performance on physical integrity rights across an extensive bundle of indicators. Therefore, this indicator is not just dependent on observed violence against civilians but it also incorporates other forms of state repressive behavior such as torture, ill-treatment of prisoners, unlawful imprisonment of citizens, and state-led threatening events. Second, the latent human rights protection scores cover more countries (e.g., 194 countries in 2019) than any individual data source by combining information from all other data sources. For instance, another frequently used alternative dataset of human rights protection, the CIRI dataset, was discontinued in 2011 (Cingranelli and Richards, 1999). The latent human rights protection scores, thus, enables us to evaluate our main hypotheses using a global sample of 182 countries.

We include three sets of controls to our models: political, population and economic, and public health controls. First, in terms of political variables the literature identifies as important to control for, we include democratic political institutions, state capacity, and a history of intrastate conflict in the country (Hill Jr and Jones, 2014). We rely on the V-Dem polyarchy index to measure democratic political institutions (Teorell, Coppedge, 
Lindberg and Skaaning, 2019), ${ }^{8}$ State capacity is also added to control for variation in the capacity of states to credibly formulate and implement policies such as stay-at-home orders as well as repressive policies. While there are a number of indicators of state capacity in the literature, ${ }^{9}$ we employ Government Effectiveness from the World Bank Indicators (World Bank, 2020) because of its conceptual clarity, as it measures "the quality of policy formulation and implementation, and the credibility of the government's commitment to such policies;" and, extensive coverage with over 190 countries in the dataset. ${ }^{10}$ Finally, we also include a measure of historical intrastate conflict in the country that takes the value of 1 if the country has been involved in an intrastate militarized dispute in the period 1946-2004 from the PRIO Dataset (Gleditsch, Wallensteen, Eriksson, Sollenberg and Strand, 2002).

Our second and third sets of controls include population, economic, and healthrelated indicators. Population density, economic development, and economic growth are major determinants of state repression (Hill Jr and Jones, 2014), which could also be associated with pandemic responses. GDP per capita is based on purchasing power parity (PPP) in 2019 and expressed in 2011 international dollars, and annual GDP growth in 2019 - or the most recent year if absent - is used to measure economic development (World Bank, 2020). ${ }^{11}$ We also include health-related factors that could be associated with state repression, a country's risk of exposure to the pandemic, and policy responses to the COVID-19: the share of the population aged 70 or above, diabetes prevalence, and cardiovascular death rate. The main criteria for using these health indicators is having extensive country coverage. While we aim to control for factors that may be associated with a country's exposure to the pandemic, we also want to minimize reductions in sample size which may undermine the generalizability of our findings.

\footnotetext{
${ }^{8}$ Missing values in V-Dem polyarchy index have been filled with the predicted values from the Freedom House ratings using an ordinary least squares equation.

${ }^{9}$ For an interesting review on state capacity indicators, see (Vaccaro, 2020). In this review, Vaccaro (2020) reports a high correlation $(>0.8)$ with all other available indicators of state capacity.

${ }^{10}$ The Online Appendix G evaluates the robustness of our findings to the use of alternative measures of state capacity. None of our findings depend on what measure of state capacity we choose.

${ }^{11}$ Missing values in GDP per capita have been filled with information from the CIA Factbook.
} 


\section{Research Design}

In what follows, we give an overview of our research design for testing each of our three hypotheses. First, we build a cross-sectional dataset to assess whether countries with a lower human rights record or a recent history of repression against civilians are more likely to implement restrictive measures such as stay-at-home orders. To evaluate our first hypothesis, we create a binary variable that takes the value of 1 if the country implemented a stay-athome order anytime between January 1, 2020, and August 31, 2020, and 0 otherwise. We then implement a set of logistic regressions where the adoption of a stay-at-home order in the country is regressed on the level of protection of human rights or the repression against civilians immediately before the beginning of the pandemic together with our extensive set of control variables and region fixed-effects.

For our second hypothesis, the outcome variable is the timing of implementation of stay-at-home orders in the country. The outcome variable is operationalized as the number of days between the first confirmed case of COVID-19 in a country and the adoption of a stayat-home order, either a lockdown or a curfew. We run a set of proportional hazard models to evaluate whether those countries with a lower protection of human rights or greater state repression against civilians before the outbreak implement restrictive measures more quickly than countries with no such background or record. Our extensive set of control variables and region fixed-effects are included in these models.

Finally, we evaluate our third hypothesis by creating a variable that captures the number of days, either consecutive or not, that a country has had a stay-at-home order in place between January 1, 2020, and August 31, 2020. We then employ OLS regression models where the number of days with a stay-at-home order in the country during our time period is regressed on the level of protection of human rights or the repression against civilians immediately before the beginning of the pandemic, as well as our extensive set of control variables and region fixed-effects. 


\section{Results}

In this section, we provide our evaluation for our three hypotheses in three separate subsections.

\section{Are Repressive States More Likely to Impose Stay-at-home Orders?}

We first examine whether countries that used greater violence against civilians in 2019 are more likely to implement stay-at-home orders compared to countries with no recent history of using violence against civilians. We also re-estimate the model using a measure of human rights as opposed to state violence.

Table 1 report a set of logistic regressions that model whether a stay-at-home order was adopted in the country as a function of the recent record of violence against civilians in the year preceding the outbreak or a country's human rights protection score. Both models sequentially incorporate region fixed effects, political, economic, and health control variables.

Columns 1 through 4 show that the estimated effect of recent state repression is positive and significant at the $99 \%$ confidence level for the unadjusted model and significant at the $90 \%$ level in the fully-adjusted model, indicating that countries with a recent history of violence against civilians are more likely to adopt stay-at-home order. Figure 2 illustrates the size of the effect. For one-unit increase in the logged number of ACLED violent events ${ }^{12}$ - e.g., going from the mean of 6 violent events to 16 violent events - increases the expected probability of a stay-at home order by approximately 10 percent when averaged over the sample values of control variables.

Similarly, Columns 5 through 8 also indicate that the estimated effect of human rights score before the beginning of the pandemic is significantly associated with the adoption of a stay-at-home order with a negative coefficient that is significant at the $99 \%$ confidence levels across all models. The negative coefficients indicate that countries whose human rights scores

\footnotetext{
${ }^{12} 1-\log$ is roughly equivalent to one standard deviation $(\mathrm{sd}=1.03)$ in the distribution of the number of ACLED events.
} 
Table 1: Logistic regressions on the effect of state repression and human rights scores on adopting stay-at-home orders

\begin{tabular}{|c|c|c|c|c|c|c|c|c|}
\hline & \multicolumn{8}{|c|}{ DV: Adoption of a stay-at-home order } \\
\hline & $(1)$ & $(2)$ & (3) & $(4)$ & $(5)$ & $(6)$ & $(7)$ & $(8)$ \\
\hline $\begin{array}{l}\mathrm{N} \text { of violent events }(\mathrm{log}) \\
\text { (per one million population) }\end{array}$ & $\begin{array}{c}0.66^{* * *} \\
(0.24)\end{array}$ & $\begin{array}{l}0.59^{* *} \\
(0.26)\end{array}$ & $\begin{array}{l}0.71^{* *} \\
(0.28)\end{array}$ & $\begin{array}{l}0.64^{* *} \\
(0.30)\end{array}$ & & & & \\
\hline Human Rights Protection Score & & & & & $\begin{array}{c}-0.55^{* * *} \\
(0.14)\end{array}$ & $\begin{array}{c}-0.58^{* * *} \\
(0.20)\end{array}$ & $\begin{array}{c}-0.69^{* * *} \\
(0.21)\end{array}$ & $\begin{array}{c}-0.70^{* * *} \\
(0.22)\end{array}$ \\
\hline Democracy score (V-Dem) & & $\begin{array}{l}-0.78 \\
(1.13)\end{array}$ & $\begin{array}{l}-0.09 \\
(1.19)\end{array}$ & $\begin{array}{c}1.39 \\
(1.44)\end{array}$ & & $\begin{array}{c}0.59 \\
(1.11)\end{array}$ & $\begin{array}{c}1.74 \\
(1.20)\end{array}$ & $\begin{array}{l}3.35^{* *} \\
(1.39)\end{array}$ \\
\hline State Capacity & & $\begin{array}{c}0.06 \\
(0.38)\end{array}$ & $\begin{array}{l}-0.70 \\
(0.53)\end{array}$ & $\begin{array}{c}0.12 \\
(0.59)\end{array}$ & & $\begin{array}{l}-0.02 \\
(0.29)\end{array}$ & $\begin{array}{c}-0.72^{*} \\
(0.42)\end{array}$ & $\begin{array}{l}-0.09 \\
(0.47)\end{array}$ \\
\hline $\begin{array}{l}\text { Intrastate Armed Conflict } \\
\text { (Historical) }\end{array}$ & & $\begin{array}{c}0.47 \\
(0.45)\end{array}$ & $\begin{array}{c}0.62 \\
(0.47)\end{array}$ & $\begin{array}{l}0.88^{*} \\
(0.52)\end{array}$ & & $\begin{array}{c}0.40 \\
(0.42)\end{array}$ & $\begin{array}{c}0.54 \\
(0.44)\end{array}$ & $\begin{array}{c}0.72 \\
(0.47)\end{array}$ \\
\hline GDP per capita (log) & & & $\begin{array}{l}0.84^{* *} \\
(0.41)\end{array}$ & $\begin{array}{c}0.68 \\
(0.46)\end{array}$ & & & $\begin{array}{l}0.70^{* *} \\
(0.34)\end{array}$ & $\begin{array}{c}0.34 \\
(0.38)\end{array}$ \\
\hline GDP Annual Growth & & & $\begin{array}{c}0.03 \\
(0.07)\end{array}$ & $\begin{array}{c}0.01 \\
(0.08)\end{array}$ & & & $\begin{array}{l}-0.05 \\
(0.06)\end{array}$ & $\begin{array}{l}-0.07 \\
(0.07)\end{array}$ \\
\hline Population Density ('000) & & & $\begin{array}{c}0.92 \\
(1.18)\end{array}$ & $\begin{array}{c}1.98 \\
(1.69)\end{array}$ & & & $\begin{array}{c}0.38 \\
(0.39)\end{array}$ & $\begin{array}{c}0.36 \\
(0.38)\end{array}$ \\
\hline $\begin{array}{l}\text { Population aged } 70 \\
\text { or older (percentage) }\end{array}$ & & & & $\begin{array}{l}-0.32^{* *} \\
(0.14)\end{array}$ & & & & $\begin{array}{l}-0.14 \\
(0.10)\end{array}$ \\
\hline Diabetes prevalence & & & & $\begin{array}{l}0.19^{*} \\
(0.11)\end{array}$ & & & & $\begin{array}{c}0.26^{* * *} \\
(0.09)\end{array}$ \\
\hline Cardiovascular death rate & & & & $\begin{array}{c}0.01^{* *} \\
(0.003)\end{array}$ & & & & $\begin{array}{c}0.004^{*} \\
(0.002)\end{array}$ \\
\hline Region FE & Yes & Yes & Yes & Yes & Yes & Yes & Yes & Yes \\
\hline Observations & 135 & 135 & 135 & 135 & 182 & 180 & 180 & 178 \\
\hline
\end{tabular}

${ }^{*} \mathrm{p}<0.1 ;{ }^{* *} \mathrm{p}<0.05 ;{ }^{* * *} \mathrm{p}<0.01$. Standard errors in parenthesis. Region-Fixed Effects include: Africa, Asia, Europe, North America, South America, and Oceania. Constant omitted from the output.

are lower are more likely to adopt stay-at-home orders. Figure 2 also shows that this effect is sizable. Countries whose human rights score increases by one unit, or approximately 1-SD, have a 10-20 percent lower chance of having a stay-at-home order imposed when averaged over the sample values of control variables. 
Figure 2: Change in Marginal Probabilities of Stay-at-Home Orders Given History of Repression and Human Rights Protection Scores

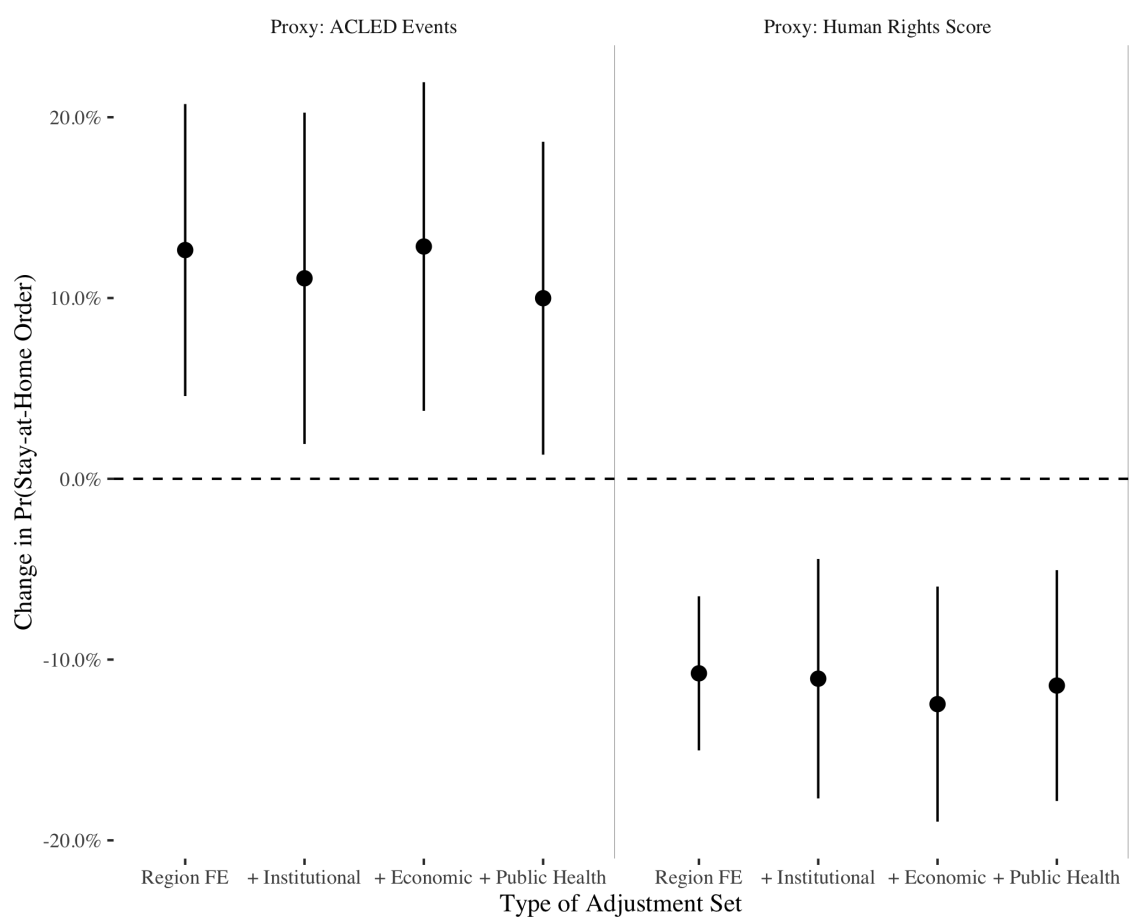

Figure shows sample average marginal changes in the probability of a stay-at-home order being imposed during the sample period given a one-unit increase in the explanatory variables. Points are point estimates and the intervals are the $5 \%$ to $95 \%$ confidence interval. Models are listed in terms of which controls are added to the model; see Table 1 for the full list of controls added to each model.

The empirical patterns provide support to the argument that abusive governments, as measured by either a measure of observed violence in the preceding year or combined human rights scores before the pandemic, are more likely to implement restrictive policies against the COVID-19.

\section{Are Repressive States Quicker in Imposing Stay-at-home Orders?}

We begin by considering some graphical descriptive evidence to evaluate our second hypothesis. Figure 3 plots the cumulative probability that a state did not implement a stay at home order starting from the day of the first COVID-19 case (right-censored at August 31, 2020) to the adoption of a stay-at-home policy in at least one of the country's regions. ${ }^{13}$

\footnotetext{
${ }^{13}$ Or the equivalent to the first subnational division in the country.
} 
The color of the lines and the $95 \%$ confidence intervals indicate whether the country had a below-median (blue) or above-median (yellow) level of state repression in 2019 (Figure 1a), or a below-median (blue) or above-median (yellow) combined score in the protection of human rights.

The difference in slopes between countries that are below versus above the median in terms of a history of repressing their citizens or violating basic human rights suggests that there is a relationship between using violence against civilians or a poor record of human rights and the timing of imposing restrictive measures in responding to the pandemic. Abusive governments implemented a stay-at-home order on average 25 days after the first confirmed case- when measured as an above-the-median number of violent events against civilians in 2019 - and 35 days - when measured as a below-the-median human rights score. In contrast, countries that had a below-the-median level of violence against civilians in 2019 take on average 35 days to implement a stay-at-home order while countries that had an above-the-median in the protection of human rights score take on average 95 days. ${ }^{14}$

It is clear from this descriptive evidence that countries that have used violence against civilians in the months preceding the occurrence of its first COVID-19 case or score low in the protection of human rights have implemented restrictive measures more quickly than similar countries that have had no recent history of using violence against civilians or a record of violating human rights. However, this evidence is only suggestive given that it relies on a crude measure of violence - a simple dummy based on above and below the median of events and human right scores - and does not control for potential confounders.

For a more robust analysis, Table 2 reports Cox proportional hazards models that estimate the number of days from the first COVID-19 confirmed case in the country to the adoption of a stay-at-home order given the number of events involving violence against civilians and the number of fatalities in these events. We note that in Cox proportional hazards regression models, coefficients indicate the hazard rate, i.e. is the risk of "failure"

\footnotetext{
${ }^{14}$ The differences in slopes are statistically significant when using both the number of events (log-rank test, $p<0.01)$ and the human rights scores (log-rank test, $p<0.01)$.
} 
Figure 3: Survival probability plots of COVID-19 policy response by preceding violence against civilians and human rights protection scores

(a) Number of events of violence against civilians

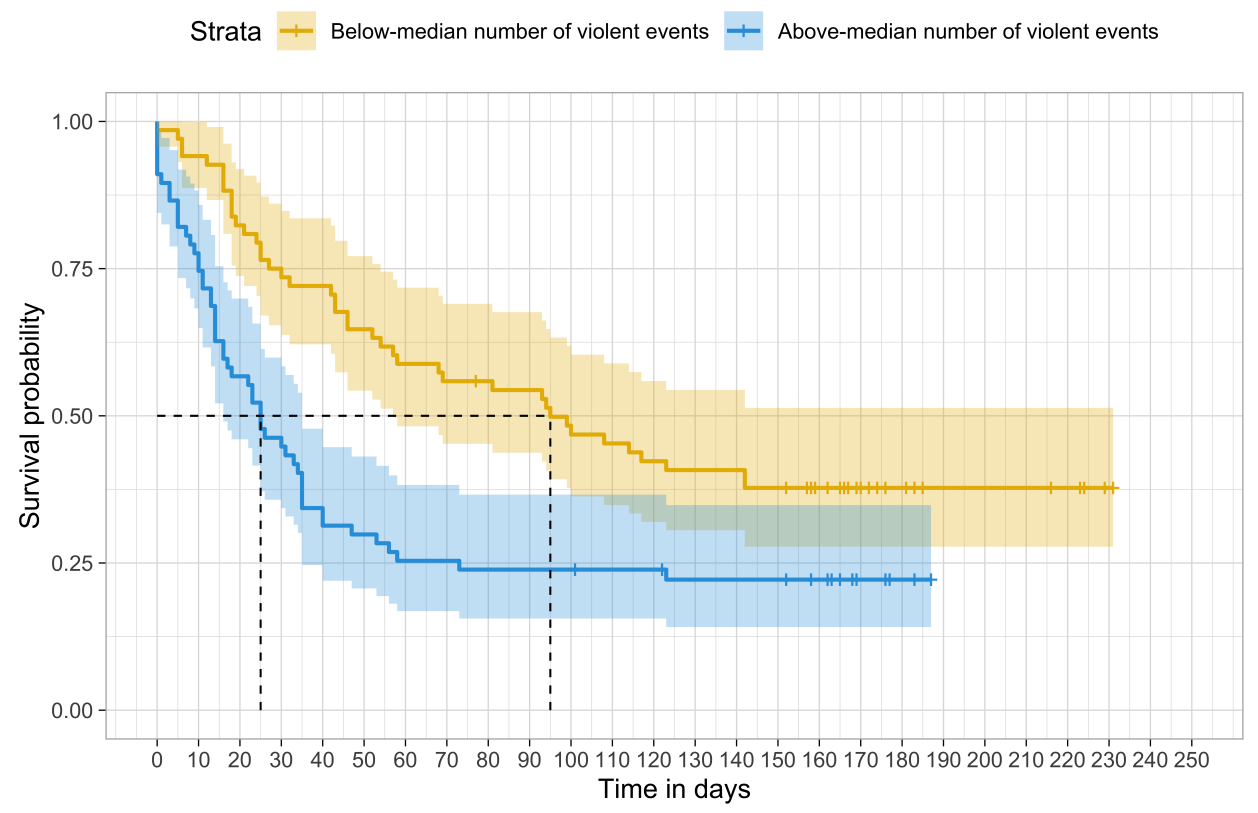

(b) Human rights protection

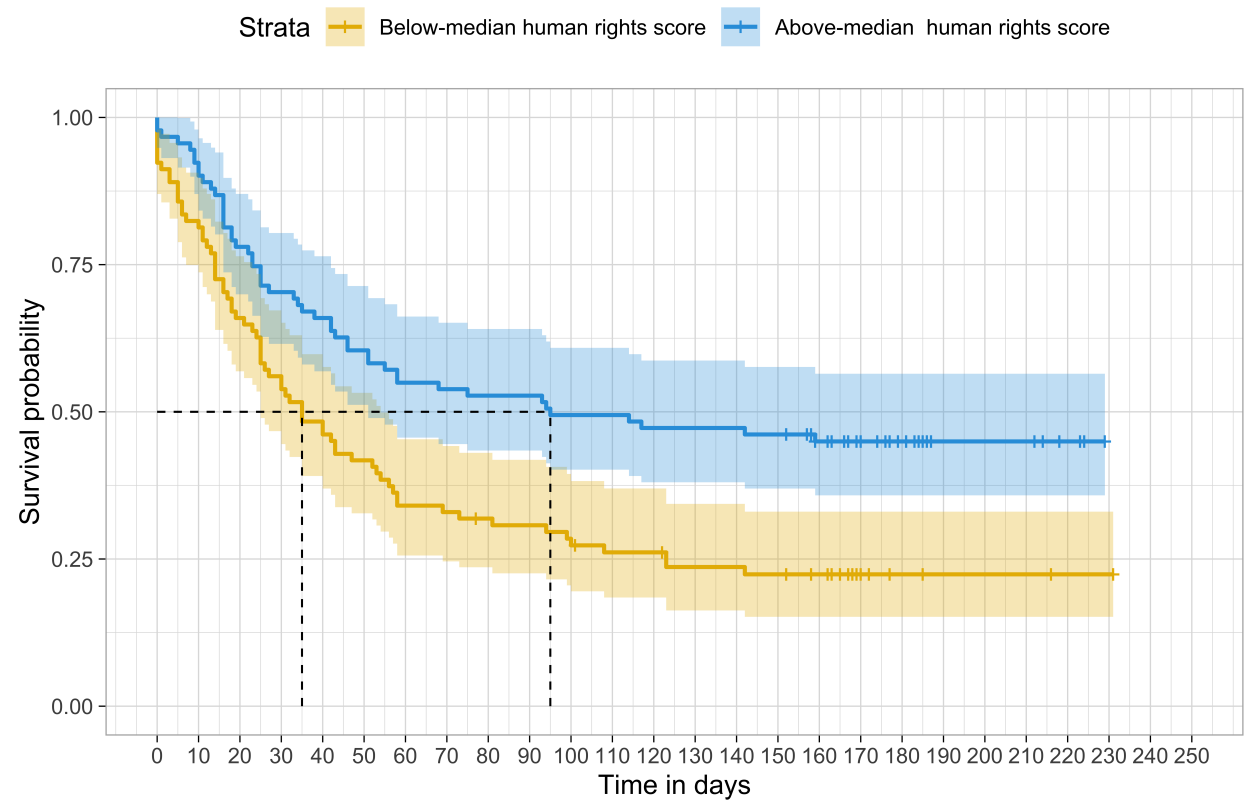

(in this case, the probability of adopting a stay-at-home order), given that the event has not yet occurred (in this case, given that the country has not already implemented a stayat-home order). Therefore, predictors with positive coefficients are factors that increase the 
Table 2: Cox proportional hazards models of estimating the effect of state repression in 2019 and human rights scores on the time to adopting a stay-at-home order

\begin{tabular}{|c|c|c|c|c|c|c|c|c|}
\hline & \multicolumn{8}{|c|}{ Days from 1st COVID-19 confirmed case to stay-at-home order } \\
\hline & $(1)$ & $(2)$ & $(3)$ & $(4)$ & $(5)$ & $(6)$ & $(7)$ & $(8)$ \\
\hline $\begin{array}{l}\mathrm{N} \text { of violent events }(\mathrm{log}) \\
\text { (per one million population) }\end{array}$ & $\begin{array}{c}0.48^{* * *} \\
(0.10)\end{array}$ & $\begin{array}{c}0.43^{* * *} \\
(0.11)\end{array}$ & $\begin{array}{c}0.49^{* * *} \\
(0.12)\end{array}$ & $\begin{array}{c}0.45^{* * *} \\
(0.12)\end{array}$ & & & & \\
\hline Human Rights Protection Score & & & & & $\begin{array}{c}-0.32^{* * *} \\
(0.07)\end{array}$ & $\begin{array}{c}-0.30^{* * *} \\
\quad(0.11)\end{array}$ & $\begin{array}{c}-0.32^{* * *} \\
(0.10)\end{array}$ & $\begin{array}{c}-0.30^{* * *} \\
(0.11)\end{array}$ \\
\hline Democracy score (V-Dem) & & $\begin{array}{l}-0.31 \\
(0.59)\end{array}$ & $\begin{array}{c}0.02 \\
(0.62)\end{array}$ & $\begin{array}{c}0.68 \\
(0.70)\end{array}$ & & $\begin{array}{c}0.49 \\
(0.59)\end{array}$ & $\begin{array}{c}0.95 \\
(0.62)\end{array}$ & $\begin{array}{l}1.56^{* *} \\
(0.69)\end{array}$ \\
\hline State Capacity & & $\begin{array}{l}-0.22 \\
(0.20)\end{array}$ & $\begin{array}{c}-0.66^{* *} \\
(0.26)\end{array}$ & $\begin{array}{l}-0.46 \\
(0.28)\end{array}$ & & $\begin{array}{c}-0.29^{*} \\
(0.16)\end{array}$ & $\begin{array}{c}-0.61^{* * *} \\
(0.22)\end{array}$ & $\begin{array}{r}-0.45^{*} \\
(0.23)\end{array}$ \\
\hline $\begin{array}{l}\text { Intrastate Armed Conflict } \\
\text { (Historical) }\end{array}$ & & $\begin{array}{l}-0.09 \\
(0.25)\end{array}$ & $\begin{array}{c}0.04 \\
(0.26)\end{array}$ & $\begin{array}{c}0.12 \\
(0.26)\end{array}$ & & $\begin{array}{c}0.01 \\
(0.24)\end{array}$ & $\begin{array}{c}0.11 \\
(0.24)\end{array}$ & $\begin{array}{c}0.14 \\
(0.25)\end{array}$ \\
\hline GDP per capita (log) & & & $\begin{array}{l}0.47^{* *} \\
(0.18)\end{array}$ & $\begin{array}{l}0.42^{* *} \\
(0.21)\end{array}$ & & & $\begin{array}{l}0.33^{*} \\
(0.17)\end{array}$ & $\begin{array}{c}0.19 \\
(0.19)\end{array}$ \\
\hline GDP Annual Growth & & & $\begin{array}{c}0.04 \\
(0.04)\end{array}$ & $\begin{array}{c}0.01 \\
(0.04)\end{array}$ & & & $\begin{array}{l}-0.01 \\
(0.03)\end{array}$ & $\begin{array}{l}-0.02 \\
(0.03)\end{array}$ \\
\hline Population Density ('000) & & & $\begin{array}{c}0.46 \\
(0.46)\end{array}$ & $\begin{array}{c}0.60 \\
(0.47)\end{array}$ & & & $\begin{array}{c}0.20 \\
(0.14)\end{array}$ & $\begin{array}{c}0.18 \\
(0.14)\end{array}$ \\
\hline $\begin{array}{l}\text { Population aged } 70 \\
\text { or older (percentage) }\end{array}$ & & & & $\begin{array}{l}-0.10 \\
(0.06)\end{array}$ & & & & $\begin{array}{l}-0.02 \\
(0.05)\end{array}$ \\
\hline Diabetes prevalence & & & & $\begin{array}{c}0.03 \\
(0.04)\end{array}$ & & & & $\begin{array}{c}0.09^{* * *} \\
(0.03)\end{array}$ \\
\hline Cardiovascular death rate & & & & $\begin{array}{l}0.002^{*} \\
(0.001)\end{array}$ & & & & $\begin{array}{c}0.001 \\
(0.001)\end{array}$ \\
\hline Region FE & Yes & Yes & Yes & Yes & Yes & Yes & Yes & Yes \\
\hline Observations & 135 & 135 & 135 & 135 & 182 & 180 & 180 & 178 \\
\hline
\end{tabular}

${ }^{*} \mathrm{p}<0.1 ;{ }^{* *} \mathrm{p}<0.05 ;{ }^{* * *} \mathrm{p}<0.01$. Standard errors in parenthesis. Region-Fixed Effects include:

Africa, Asia, Europe, North America, South America, and Oceania.

likelihood that a policy is implemented more quickly.

The Cox models show that countries that experienced a greater number of fatalities 
from violence against civilians in the months immediately preceding the pandemic are more likely to implement stay-at-home orders earlier than those with no recent record of violence against civilians. Table 2 consistently indicates a positive and statistically significant effect at the $99 \%$ confidence level with and without adjusting for control variables (columns 1 through 4). These estimated effects are also substantively sizable. We can interpret these numbers by calculating expected duration; i.e., the average number of days until a policy is implemented holding the covariates constant (Harden and Kropko, 2019). Using our saturated model, we can calculate that the average time until adoption of a stay-at-home order varies from 120 days after the first COVID case for a country with a prior history of only 1.4 violent events in 2019 (the 25th percentile) to 72 days after the first COVID case for a country with a comparatively higher history of 5.5 violent events in 2019 (the 75 th percentile), which means a difference of 48 days.

Table 2 also reports a consistent negative effect of the latent human rights protection score on the adoption of stay-at-home order, indicating that countries that often violate human rights adopted stay-at-home orders earlier in the pandemic compared to otherwise similar countries with better scores in the index of human rights protection. Based on our saturated model, we can calculate that an increase in the human rights protection score from -0.37 to +1.88 , which corresponds to the 25 th and 75 th percentiles, is associated with a time from the first case until the implementation of a stay-at-home order that is longer by 50 days: from 86 days (25th percentile) to 136 days (75th percentile).

\section{Are Repressive States More Likely to Impose Longer Stay-at-home}

\section{Orders?}

Lastly, we evaluate whether countries that had used violence against civilians in the months preceding the beginning of the pandemic and countries that have a poor record of human rights are more likely to impose longer stay-at-home orders than countries with no recent history of using violence against civilians or with a better record of human rights. 
Table 3 estimates the effect of a recent history of state repression against civilians on the length of stay-at-home orders in the country using an OLS model (columns 1-4). The main explanatory predictor in columns is the log of the number of events per one million population from state-led violence against civilians. As above, models are adjusted for major predictors of repression (regime type, state capacity, economic development, domestic war history, economic growth, and population density) and country-specific predictors of the pandemic risk (population aging and two indicators of pre-pandemic health status).

The results in Table 3 indicate that the log in the number of events per one million population is associated with the imposition of longer stay-at-home orders during the pandemic across all models with a $99 \%$ confidence level. In the unadjusted model, column 1 shows that a $10 \%$ increase in the number of fatalities per one million population would are associated with an increase in the length of stay-at-home orders of $4.7 \%\left(e^{0.48 \cdot \log (1.1}\right)$. In the model that adjusts for all control variables, Model 4 shows that a $10 \%$ increase in the number of fatalities leads, on average, to an expected increase of the duration of a stay-athome order in place of $4.4 \%\left(e^{0.45 \cdot \log (1.1}\right)$. Simulating the extreme values in the interquantile range, our coefficient in the fully-adjusted model indicates that a number of ACLED violent events of 1.4 (25th percentile) leads to an expected stay-at-home order of 25 days long, which is 23 days shorter than the 48-day-long stay-at-home order expected in a country with 5.5 ACLED violent episodes (75th percentile).

Table 3 also shows a negative association between the latent human rights protection scores and the imposition of longer restrictive policies against the COVID-19, which indicates that countries that better protect the human rights of their citizens are likely to impose restrictions for shorter periods relative to countries that have worse human right protection scores. These effects are significant at the $99 \%$ confidence level across all model specifications. Using the unadjusted model (column 5), the coefficient indicates that 1SD increase in the latent human rights protection score from the average - an increase from the average score of 0.77 to 2.44 , equivalent to $1 \mathrm{SD}$ above the mean - would imply an expected decrease in 
Table 3: OLS regressions on the effect of recent violence against civilians and human rights score on the length of stay-at-home orders

\begin{tabular}{|c|c|c|c|c|c|c|c|c|}
\hline & \multicolumn{8}{|c|}{ Number of days with a stay-at-home order in the country (log) } \\
\hline & $(1)$ & $(2)$ & $(3)$ & $(4)$ & $(5)$ & $(6)$ & $(7)$ & $(8)$ \\
\hline $\begin{array}{l}\mathrm{N} \text { of violent events }(\mathrm{log}) \\
\text { (per one million population) }\end{array}$ & $\begin{array}{c}0.59^{* * *} \\
(0.18)\end{array}$ & $\begin{array}{l}0.47^{* *} \\
(0.20)\end{array}$ & $\begin{array}{c}0.53^{* * *} \\
(0.20)\end{array}$ & $\begin{array}{l}0.47^{* *} \\
(0.19)\end{array}$ & & & & \\
\hline Human Rights Protection Score & & & & & $\begin{array}{c}-0.41^{* * *} \\
(0.09)\end{array}$ & $\begin{array}{c}-0.53^{* * *} \\
\quad(0.15)\end{array}$ & $\begin{array}{c}-0.58^{* * *} \\
(0.15)\end{array}$ & $\begin{array}{c}-0.52^{* * *} \\
\quad(0.15)\end{array}$ \\
\hline Democracy score (V-Dem) & & $\begin{array}{l}-0.63 \\
(1.19)\end{array}$ & $\begin{array}{l}-0.12 \\
(1.24)\end{array}$ & $\begin{array}{c}1.02 \\
(1.19)\end{array}$ & & $\begin{array}{c}1.11 \\
(0.88)\end{array}$ & $\begin{array}{l}1.78^{* *} \\
(0.90)\end{array}$ & $\begin{array}{c}2.63^{* * *} \\
(1.00)\end{array}$ \\
\hline State capacity & & $\begin{array}{l}-0.15 \\
(0.31)\end{array}$ & $\begin{array}{l}-0.62 \\
(0.42)\end{array}$ & $\begin{array}{l}-0.12 \\
(0.40)\end{array}$ & & $\begin{array}{c}0.06 \\
(0.22)\end{array}$ & $\begin{array}{c}-0.60^{*} \\
(0.33)\end{array}$ & $\begin{array}{l}-0.26 \\
(0.32)\end{array}$ \\
\hline $\begin{array}{l}\text { Intrastate Armed Conflict } \\
\text { (Historical) }\end{array}$ & & $\begin{array}{c}0.34 \\
(0.41)\end{array}$ & $\begin{array}{c}0.43 \\
(0.42)\end{array}$ & $\begin{array}{c}0.58 \\
(0.42)\end{array}$ & & $\begin{array}{c}0.38 \\
(0.38)\end{array}$ & $\begin{array}{c}0.48 \\
(0.37)\end{array}$ & $\begin{array}{c}0.59 \\
(0.37)\end{array}$ \\
\hline GDP per capita (log) & & & $\begin{array}{l}0.56^{*} \\
(0.31)\end{array}$ & $\begin{array}{c}0.47 \\
(0.37)\end{array}$ & & & $\begin{array}{c}0.62^{* * *} \\
(0.24)\end{array}$ & $\begin{array}{c}0.42 \\
(0.28)\end{array}$ \\
\hline GDP Annual Growth & & & $\begin{array}{c}0.01 \\
(0.06)\end{array}$ & $\begin{array}{l}-0.03 \\
(0.06)\end{array}$ & & & $\begin{array}{l}-0.05 \\
(0.05)\end{array}$ & $\begin{array}{l}-0.08 \\
(0.05)\end{array}$ \\
\hline Population Density ('000) & & & $\begin{array}{c}0.33 \\
(0.68)\end{array}$ & $\begin{array}{c}0.59 \\
(0.94)\end{array}$ & & & $\begin{array}{c}0.28 \\
(0.44)\end{array}$ & $\begin{array}{c}0.25 \\
(0.55)\end{array}$ \\
\hline $\begin{array}{l}\text { Population aged } 70 \text { or older } \\
\text { (percentage) }\end{array}$ & & & & $\begin{array}{c}-0.25^{* * *} \\
(0.08)\end{array}$ & & & & $\begin{array}{l}-0.05 \\
(0.05)\end{array}$ \\
\hline Diabetes prevalence & & & & $\begin{array}{c}0.07 \\
(0.07)\end{array}$ & & & & $\begin{array}{l}0.11^{* *} \\
(0.05)\end{array}$ \\
\hline Cardiovascular death rate & & & & $\begin{array}{c}0.004^{*} \\
(0.002)\end{array}$ & & & & $\begin{array}{c}0.003^{*} \\
(0.002)\end{array}$ \\
\hline Region FE & Yes & Yes & Yes & Yes & Yes & Yes & Yes & Yes \\
\hline Observations & 135 & 135 & 135 & 135 & 182 & 180 & 180 & 178 \\
\hline
\end{tabular}

${ }^{*} \mathrm{p}<0.1 ;{ }^{* *} \mathrm{p}<0.05 ;{ }^{* * *} \mathrm{p}<0.01$. Robust standard errors in parenthesis. Region-Fixed Effects include: Africa, Asia, Europe, North America, South America, and Oceania. Constant omitted from the output. 
the length of stay-at-home orders of 24 days - from 49 to 25 days of a stay-at-home order policy in place. After adjusting for all covariates, Model 8 shows a similar effect in which 1SD increase in the latent human rights protection scores form the mean would lead to a stay-at-home order 28 days shorter - from 48 to 20 days of a stay-at-home order policy in place.

We can illustrate the size of these effects using the country of Moldova. ${ }^{15}$ Moldova experienced 6 violent events against civilians in 2019, which is equivalent to 1.49 violent events per one million population. In this country, we observe that the stay-at-home order was in place for 95 days during our period of study. Using the fully-adjusted model in column 4, we predict that if the number of violent events against civilians had been 12 rather than 6-from 1.48 to 2.96 per one million population - the expected length of the stay-at-home order would be 131 days - 36 days longer than its observed value. At the same time, if Moldova's human rights protection score in 2019 - 0.23 - were the same as Moldova's score back in 2015 - 0.77 - we would expect a reduction of the length of stay-at-home order in place by 23 days — from 95 days to 72 days.

\section{Discussion and Conclusions}

This study has investigated whether countries with a recent record of state-led violence against civilians or worse protection of human rights have been more likely to impose severe restrictions on the freedom of movement, impose them earlier on, and impose them for longer periods amidst the COVID-19 pandemic. We argue this should be the case because abusive governments may see restrictive preventive measures not only as a tool to achieve public health objectives but also to control domestic challengers. While an empirical test of the true intentions of governments is not possible, we have generated and empirically examined three empirical observations that are consistent with our theoretical argument. Consistent

\footnotetext{
${ }^{15}$ We choose Moldova because it has values close to the median of the sample in both the number of violent events per one million population in 2019 - the median sample is 1.15 and the value for Moldova is $1.49-$ and the latent human rights protection scores - the median sample is 0.60 and score for Moldavia is 0.23 .
} 
with our expectations, we find that abusive governments have been more likely to restrict citizens' freedom of movement through stay-at-home orders at anytime during our period of study. Further, we also find that abusive governments have been quicker to restrict citizens' freedom of movement through stay-at-home orders. Lastly, we also observe that abusive governments have also kept restrictive measures in place for longer.

We acknowledge that several methodological decisions have been made in the analysis and some concerns might remain. Consequently, we have subjected our empirical models to several robustness checks by: (1) varying time-to-policy thresholds (see Online Appendix C); (2) time windows of the pre-outbreak measure of the ACLED violence against civilians (see the Online Appendix D); (3) the actors involved in the ACLED violence against civilians (see Online Appendix E); (4) using an expanded ACLED country coverage (see Online Appendix F); (5) using an alternative indicator for state capacity (see Online Appendix G); (6) adding two controls to capture countries' capacity to enforce a stay-at-home order, namely (i) the number of military personnel available to the national government as a share of the total population and (ii) the number of active police officers per 100,000 population (see Online Appendix H); and, (7) controlling for trust in government (see Online Appendix I). The rationale for each of the robustness checks can be found on its corresponding Appendix. We conclude that our conclusions remain unaltered across all measurement decisions and model specifications.

Beyond these findings' contribution to our understanding of the relations between global crisis, the governmental response, and domestic dissidents outlined above, the present paper has significant practical implications. From a policy perspective, international organizations, such as the United Nations, have recently raised initial concerns about how governments may use the COVID-19 pandemic as a pretext to heightened state repression and the violation of fundamental civil liberties. ${ }^{16}$ Human rights organizations have also ex-

\footnotetext{
${ }^{16}$ See the UN document submitted by Irene Kahn, the UN Special Rapporteur on the promotion and protection of the right to freedom of opinion and expression, A/HRC/44/49, and accessible on https: //undocs.org/A/HRC/44/49.
} 
pressed similar concerns, warning how state of emergency policies may be adopted by some governments with the intention to undermine civil and political rights (Hammadi, 2020). In this vein, Sam Brownback, Ambassador at Large for International Religious Freedom from the U.S. Department of State, has specifically warned that autocratic governments may be using the COVID-19 policies as a tool for political repression, "imposing additional on already marginalized ethnic communities".

While international organizations, governments, and pundits alike may have raised concerns about the unwarranted use of extraordinary measures, their statements and their evidence backing them have lacked high confidence or clear evidence because many of the large-scale non-pharmaceutical interventions implemented during this health crisis are indistinguishable from repressive campaigns. This paper opens the black box by providing positive and systematic evidence consistent with the misuse of COVID-19 policies as a tool for political repression among abusive states. Overall, our findings indicate that the international community should closely monitor the adoption of stay-at-home orders to ensure that they follow the standards of necessity and proportionality.

Whereas the empirical scope of this paper is limited to establishing these association in the context of the COVID-19 pandemic, our theoretical logic could travel to situations other than pandemics. The general logic of our argument is that international actors only impose sanctions if both the degree of a government's domestic repression and certainty that the repression is unjustified is high. Hence, disasters that call for policies that are observationally equivalent to policies commonly used to deter domestic dissent such as lockdowns and curfews might create some degree of uncertainty about the reasons of the policy adoption. Contexts that create such uncertainty open windows of opportunity for abusive government to repress their citizens. For instance, we expect that abusive government might be more likely to embrace restrictive policies when environmental conditions predict disasters such as hurricanes, volcanic eruptions, and storms, which usually require residents to stay at home for some time. Beyond naturally occurring events, abusive authorities may 
also use events like significant air pollution (e.g., wildfire smoke) and radioactivity hazards to implement particularly restrictive measures. Though further research will be required to ascertain whether our logic extends to these other types of disasters, given that climate change-induced disasters are only likely to increase over time, the importance of such work cannot be overstated.

\section{References}

Acemoglu, Daron and James A Robinson. 2000. "Democratization or repression?" European Economic Review 44(4-6):683-693.

Afesorgbor, Sylvanus Kwaku. 2019. "The impact of economic sanctions on international trade: How do threatened sanctions compare with imposed sanctions?" European Journal of Political Economy 56:11-26.

Aksoy, Deniz, Andrew Menger and Margit Tavits. 2020. "The Effect of Curfews on Political Preferences." Working Paper .

URL: shorturl.at/EFM36

Allcott, Hunt, Levi Boxell, Jacob Conway, Matthew Gentzkow, Michael Thaler and David Y Yang. 2020. "Polarization and public health: Partisan differences in social distancing during the Coronavirus pandemic." NBER Working Paper (w26946).

Appel, Benjamin J. 2018. "In the Shadow of the International Criminal Court: Does the ICC Deter Human Rights Violations?" Journal of Conflict Resolution 62(1):3-28.

Arriola, Leonardo R and Allison N Grossman. 2020. "Ethnic marginalization and (non) compliance in public health emergencies." The Journal of Politics .

URL: https://www.journals.uchicago.edu/doi/abs/10.1086/710784

Aspinwall, Nick. 2020. "The Philippines' Coronavirus Lockdown Is Becoming a Crackdown." The Diplomat (April) . 
URL: $\quad$ https://thediplomat.com/2020/04/the-philippines-coronavirus-lockdown-isbecoming-a-crackdown/

Balcells, Laia and Jessica A Stanton. 2020. "Violence Against Civilians During Armed Conflict: Moving Beyond the Macro-and Micro-Level Divide." Annual Review of Political Science 24 .

Barceló, Joan. 2018. "Batons and ballots: The effectiveness of state violence in fighting against Catalan separatism." Research $\mathcal{E}$ Politics 5(2):1-9.

Barceló, Joan and Greg Sheen. 2020. "Voluntary adoption of social welfare-enhancing behavior: Mask-wearing in Spain during the COVID-19 outbreak." PLoS ONE 15(12):e0242764. URL: https://doi.org/10.1371/journal.pone.0242764

Brass, Paul R. 2006. "Collective violence, human rights, and the politics of curfew." Journal of Human Rights 5(3):323-340.

Buthe, Tim, Joan Barceló, Cindy Cheng, Paula Ganga, Luca Messerschmidt, Allison Spencer Hartnett and Robert Kubinec. 2020. "Patterns of Policy Responses to the COVID-19 Pandemic in Federal vs. Unitary European Democracies." Available at SSRN 3692035.

Cheng, Cindy, Joan Barceló, Allison Spencer Hartnett, Robert Kubinec and Luca Messerschmidt. 2020. "CoronaNet COVID-19 Government Response Event." Nature human behaviour 4(7):756-768.

Cingranelli, David L and David L Richards. 1999. "Measuring the level, pattern, and sequence of government respect for physical integrity rights." International studies quarterly 43(2):407-417.

Conley, Bridget and Chad Hazlett. 2019. "How very massive atrocities end: A dataset and typology.".

Conrad, Courtenay R, Jillienne Haglund and Will H Moore. 2013. "Disaggregating torture allegations: Introducing the ill-treatment and torture (ITT) country-year data." International Studies Perspectives 14(2):199-220. 
Davenport, Christian. 2007. "State repression and political order." Annual Review of Political Science 10:1-23.

DeMeritt, Jacqueline HR. 2012. "International organizations and government killing: does naming and shaming save lives?" International Interactions 38(5):597-621.

Donno, Daniela and Michael Neureiter. 2018. "Can human rights conditionality reduce repression? Examining the European Union's economic agreements." The Review of International Organizations 13(3):335-357.

Eck, Kristine and Lisa Hultman. 2007. "One-sided violence against civilians in war: Insights from new fatality data." Journal of Peace Research 44(2):233-246.

Fariss, Christopher J. 2014. "Respect for human rights has improved over time: Modeling the changing standard of accountability." American Political Science Review pp. 297-318.

Fariss, Christopher J, Michael R Kenwick and Kevin Reuning. 2020. "Estimating one-sidedkillings from a robust measurement model of human rights." Journal of Peace Research $57(6): 801-814$

Flaxman, Seth, Swapnil Mishra, Axel Gandy, H Juliette T Unwin, Thomas A Mellan, Helen Coupland, Charles Whittaker, Harrison Zhu, Tresnia Berah, Jeffrey W Eaton et al. 2020. "Estimating the effects of non-pharmaceutical interventions on COVID-19 in Europe." Nature 584(7820):257-261.

Frey, Carl Benedikt, Chinchih Chen and Giorgio Presidente. 2020. "Democracy, Culture, and Contagion: Political Regimes and Countries Responsiveness to Covid-19.".

URL: https://www.oxfordmartin.ox.ac.uk/downloads/academic/Democracy-Culture-andContagion $_{M}$ ay13.pdf

Gibney, Mark, Linda Cornett, Reed Wood, Peter Haschke, Daniel Arnon, Attilio Pisanò and Gray Barrett. 2019. "The political terror scale 1976-2018." The Political Terror Scale .

Gleditsch, Nils Petter, Peter Wallensteen, Mikael Eriksson, Margareta Sollenberg and Håvard Strand. 2002. "Armed conflict 1946-2001: A new dataset." Journal of peace research $39(5): 615-637$. 
Goldstein, Daniel and Johannes Wiedemann. 2020. "Who Do You Trust? The Consequences of Partisanship and Trust in Government for Public Responsiveness to COVID-19." Available at SSRN 3580547 .

Goldstein, Robert Justin. 1978. Political repression in modern America from 1870 to the present. Urbana and Chicago: University of Illinois Press.

Graff, Violette, Juliette Galonnier et al. 2012. Hindu-Muslim Communal Riots in India II (1986-2011). Paris: Sciences Po.

Grasse, Don, Melissa Pavlik and Hilary Matfess. 2020. "Opportunistic Repression: Patterns of civilian targeting by the state in response to COVID-19.".

URL: https://www.dropbox.com/s/xwgys9qb7ms8z2a/public $c_{h}$ ealth $h_{r}$ epression.pdf?dl $=0$

Gregory, Paul R, Philipp JH Schröder and Konstantin Sonin. 2011. "Rational dictators and the killing of innocents: Data from Stalin's archives." Journal of Comparative Economics $39(1): 34-42$.

Gruffydd-Jones, Jamie J. 2019. "Citizens and condemnation: Strategic uses of international human rights pressure in authoritarian states." Comparative Political Studies 52(4):579612.

Gurr, Ted Robert. 1986. The Political Origins of State Violence and Terror: A Theoretical Analysis. In Government Violence and Repression: An Agenda for Research, ed. Michael Stohl and George A. Lopez. Westport, CT: Greenwood Press chapter 10, pp. 45-71.

Hafner-Burton, Emilie M. 2005. "Trading human rights: How preferential trade agreements influence government repression." International Organization 59(3):593-629.

Hafner-Burton, Emilie M and Kiyoteru Tsutsui. 2005. "Human rights in a globalizing world: The paradox of empty promises." American Journal of Sociology 110(5):1373-1411.

Hammadi, Saad. 2020. "World Press Freedom Day: COVID-19 must not be a pathogen of repression." Amnesty International [Accessed: May 9, 2020].

URL: $\quad$ https://www.amnesty.org/en/latest/news/2020/05/covid-19-must-not-be-apathogen-of-repression/ 
Harden, Jeffrey J and Jonathan Kropko. 2019. "Simulating duration data for the Cox model." Political Science Research and Methods 7(4):921-928.

Hill Jr, Daniel W and Zachary M Jones. 2014. "An empirical evaluation of explanations for state repression." American Political Science Review 108(3):661-687.

Hillebrecht, Courtney. 2014. "The power of human rights tribunals: Compliance with the European Court of Human Rights and domestic policy change." European Journal of International Relations 20(4):1100-1123.

Hufbauer, Gary Clyde, Jeffrey J Schott, Kimberly Ann Elliott et al. 1990. Economic Sanctions Reconsidered: History and Current Policy. Washington DC: Institute for International Economics.

Kalyvas, Stathis N. 2006. The logic of violence in civil war. Cambridge and New York: Cambridge University Press.

Koubi, Vally. 2019. "Climate change and conflict." Annual Review of Political Science $22: 343-360$.

Krain, Matthew. 2012. "J'accuse! Does naming and shaming perpetrators reduce the severity of genocides or politicides?" International Studies Quarterly 56(3):574-589.

Kreps, David M and Robert Wilson. 1982. "Reputation and imperfect information." Journal of Economic Theory 27(2):253-279.

Kubinec, Robert, Luiz Max Carvalho, Cindy Cheng, Joan Barceló, Allison Spencer Hartnett, Luca Messerschmidt, Derek Duba and Matthew Sean Cottrell. 2020. "Partisanship and the Spread of COVID-19 in the United States.".

Lauria-Santiago, Aldo A and Jeffrey L Gould. 2008. To rise in darkness: Revolution, repression, and memory in El Salvador, 1920-1932. Durham, NC: Duke University Press.

Lebovic, James H and Erik Voeten. 2009. "The cost of shame: International organizations and foreign aid in the punishing of human rights violators." Journal of Peace Research $46(1): 79-97$. 
Lehrs, Lior. 2020. "Conflict and peace in the age of Coronavirus: Israel-Palestine as a case study." Draft manuscript .

Lyall, Jason. 2009. "Does indiscriminate violence incite insurgent attacks? Evidence from Chechnya." Journal of Conflict Resolution 53(3):331-362.

Marfleet, Philip. 2016. Egypt: Contested Revolution. London: Pluto Press.

McLean, Elena V and Dwight A Roblyer. 2017. "Public support for economic sanctions: An experimental analysis." Foreign Policy Analysis 13(1):233-254.

Murdie, Amanda M and David R Davis. 2012. "Shaming and blaming: Using events data to assess the impact of human rights INGOs." International Studies Quarterly 56(1):1-16.

Nordås, Ragnhild and Christian Davenport. 2013. "Fight the youth: Youth bulges and state repression." American Journal of Political Science 57(4):926-940.

Pavey, Eleanor. 2008. "The massacres in Sri Lanka during the Black July riots of 1983." Online Encyclopedia of Mass Violence 13.

Raleigh, Clionadh, Andrew Linke, Håvard Hegre and Joakim Karlsen. 2010. "Introducing ACLED: an armed conflict location and event dataset: special data feature." Journal of Peace Research 47(5):651-660.

Reuning, Kevin, Michael R Kenwick and Christopher J Fariss. 2019. "Exploring the dynamics of latent variable models." Political Analysis 27(4):503-517.

Ritter, Emily Hencken. 2014. "Policy disputes, political survival, and the onset and severity of state repression." Journal of Conflict Resolution 58(1):143-168.

Ritter, Emily Hencken, Courtenay R Conrad et al. 2016. "Preventing and responding to dissent: The observational challenges of explaining strategic repression." American Political Science Review 110(1):85-99.

Rozenas, Arturas. 2020. "A theory of demographically targeted repression." Journal of Conflict Resolution 64(6-7):1254-1278.

Savage, Maddy. 2020. "Lockdown, what lockdown? Sweden's unusual response to coron- 
avirus." $B B C$.

URL: https://www.bbc.com/news/world-europe-52076293

Shadmehr, Mehdi and Dan Bernhardt. 2015. "State Censorship." American Economic Journal: Microeconomics 7(2):280-307.

Siegel, David A. 2011. "When does repression work? Collective action in social networks." The Journal of Politics 73(4):993-1010.

Teorell, Jan, Michael Coppedge, Staffan Lindberg and Svend-Erik Skaaning. 2019. "Measuring polyarchy across the globe, 1900-2017." Studies in Comparative International Development 54(1):71-95.

Terman, Rochelle and Erik Voeten. 2018. "The relational politics of shame: Evidence from the universal periodic review." The Review of International Organizations 13(1):1-23.

Vaccaro, Andrea. 2020. "Measures of State Capacity: Same Same, but Different?" Quality of Government Working Paper Series .

Valentino, Benjamin A. 2014. "Why we kill: The political science of political violence against civilians." Annual Review of Political Science 17:89-103.

Walter, Barbara F. 2006. "Building reputation: Why governments fight some separatists but not others." American Journal of Political Science 50(2):313-330.

Wood, Reed M. 2008. "A Hand upon the Throat of the Nation": Economic Sanctions and State Repression, 1976-2001." International Studies Quarterly 52(3):489-513.

World Bank. 2020. "World Development Indicators Online database.". URL: https://datacatalog.worldbank.org/dataset/world-development-indicators 


\section{Online Appendix to: \\ "Windows of Repression: Using COVID-19 Policies against Political Dissidents?"}

\section{Contents}

A List of countries $\quad 3$

A.1 ACLED Models . . . . . . . . . . . . . . . . . . . . . 3

A.2 Latent Human Rights Score Models . . . . . . . . . . . . . . . . 4

B Descriptive statistics $\quad 5$

B.1 ACLED Models . . . . . . . . . . . . . . . . . . . 5

B.2 Latent Human Rights Score Models . . . . . . . . . . . . . . . . . . 6

$\begin{array}{ll}\text { C Robustness Checks to Different Time-to-policy Thresholds } & 7\end{array}$

C.1 Robustness to varying time-to-policy thresholds (Summary table) $\ldots \ldots 8$

C.2 Time to policy after the 10th confirmed COVID-19 case . . . . . . . . 9

C.3 Time to policy after the 100th confirmed COVID-19 case . . . . . . . . 10

C.4 Time to policy after the 1 st confirmed COVID-19 death . . . . . . . . . . 11

C.5 Time to policy after the 10th confirmed COVID-19 death . . . . . . . . 12

$\begin{array}{ll}\text { D Robustness to Measuring Violence using a Different Time Window } & 13\end{array}$

D.1 Re-evaluating Hypothesis 1 using the last semester of 2019 to measure violence against civilians . . . . . . . . . . . . . . . . . 14

D.2 Re-evaluating Hypothesis 2 using the last semester of 2019 to measure violence against civilians . . . . . . . . . . . . . . . . . 16

D.3 Re-evaluating Hypothesis 3 using the last semester of 2019 to measure violence

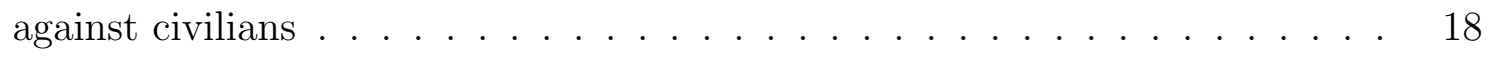


E Robustness Checks to Using All Violence Against Civilians 20

E.1 Re-evaluating Hypothesis 1 Using All Violence Against Civilians . . . . . . . 21

E.2 Re-evaluating Hypothesis 2 Using All Violence Against Civilians . . . . . . . 23

E.3 Re-evaluating Hypothesis 3 Using All Violence Against Civilians . . . . . . . 25

F Robustness Checks to Using a More Comprehensive Country Sample $\quad 27$

F.1 Re-evaluating Hypothesis 1 with an expanded country sample . . . . . . . . 29

F.2 Re-evaluating Hypothesis 2 with an expanded country sample . . . . . . . 31

F.3 Re-evaluating Hypothesis 3 with an expanded country sample . . . . . . . . 33

G Robustness to Adding an Alternative Measure of State Capacity 35

G.1 Re-evaluating Hypothesis 1 with an alternative indicator of state capacity . . 37

G.2 Re-evaluating Hypothesis 2 with an alternative indicator of state capacity . . 38

G.3 Re-evaluating Hypothesis 3 with an alternative indicator of state capacity . . 39

$\begin{array}{ll}\text { H Robustness to Police and Military Personnel } & 40\end{array}$

H.1 Re-evaluating Hypothesis 1 after controlling for army and police personnel . 41

H.2 Re-evaluating Hypothesis 2 after controlling for army and police personnel . 42

H.3 Re-evaluating Hypothesis 3 after controlling for army and police personnel . 43

I Robustness to Trust in the Government $\quad 44$

I.1 Re-evaluating Hypothesis 1 after controlling for trust in the government . . . 46

I.2 Re-evaluating Hypothesis 2 after controlling for trust in the government . . . 48

I.3 Re-evaluating Hypothesis 3 after controlling for trust in the government . . . 50 


\section{A List of countries}

\section{A.1 ACLED Models}

Afghanistan, Albania, Algeria, Angola, Antigua and Barbuda, Argentina, Armenia, Azerbaijan, Bahamas, Bahrain, Bangladesh, Barbados, Belarus, Belize, Benin, Bolivia, Bosnia and Herzegovina, Botswana, Brazil, Bulgaria, Burkina Faso, Burundi, Cambodia, Cameroon, Central African Republic, Chad, Chile, China, Colombia, Congo, Costa Rica, Croatia, Cuba, Cyprus, Czech Republic, Democratic Republic of Congo, Djibouti, Dominica, Dominican Republic, Ecuador, Egypt, El Salvador, Equatorial Guinea, Eritrea, Ethiopia, Gabon, Gambia, Georgia, Ghana, Greece, Grenada, Guatemala, Guinea, Guinea-Bissau, Guyana, Haiti, Honduras, India, Indonesia, Iran, Iraq, Israel, Jamaica, Japan, Jordan, Kazakhstan, Kenya, Kuwait, Kyrgyzstan, Laos, Lebanon, Lesotho, Liberia, Libya, Madagascar, Malawi, Malaysia, Mali, Mauritania, Mexico, Moldova, Mongolia, Montenegro, Morocco, Mozambique, Myanmar, Namibia, Nepal, Nicaragua, Niger, Nigeria, Oman, Pakistan, Palestine, Panama, Paraguay, Peru, Philippines, Qatar, Romania, Russia, Rwanda, Saint Kitts and Nevis, Saint Lucia, Saudi Arabia, Senegal, Serbia, Sierra Leone, Somalia, South Africa, South Korea, South Sudan, Sri Lanka, Sudan, Suriname, Swaziland, Syria, Taiwan, Tajikistan, Tanzania, Thailand, Togo, Trinidad and Tobago, Tunisia, Turkey, Uganda, Ukraine, United Arab Emirates, Uruguay, Uzbekistan, Venezuela, Vietnam, Yemen, Zambia, and Zimbabwe. 


\section{A.2 Latent Human Rights Score Models}

Afghanistan, Albania, Algeria, Andorra, Angola, Antigua and Barbuda, Argentina, Armenia, Australia, Austria, Azerbaijan, Bahamas, Bahrain, Bangladesh, Barbados, Belarus, Belgium, Belize, Benin, Bhutan, Bolivia, Bosnia and Herzegovina, Botswana, Brazil, Brunei, Bulgaria, Burkina Faso, Burundi, Cambodia, Cameroon, Canada, Cape Verde, Central African Republic, Chad, Chile, China, Colombia, Comoros, Costa Rica, Croatia, Cuba, Cyprus, Czech Republic, Democratic Republic of Congo, Denmark, Djibouti, Dominica, Dominican Republic, Ecuador, Egypt, El Salvador, Equatorial Guinea, Eritrea, Estonia, Ethiopia, Fiji, Finland, France, Gabon, Gambia, Georgia, Germany, Ghana, Greece, Grenada, Guatemala, Guinea, Guinea-Bissau, Guyana, Haiti, Honduras, Hungary, Iceland, India, Indonesia, Iran, Iraq, Ireland, Israel, Italy, Ivory Coast, Jamaica, Japan, Jordan, Kazakhstan, Kenya, Kosovo, Kuwait, Kyrgyzstan, Laos, Latvia, Lebanon, Lesotho, Liberia, Libya, Liechtenstein, Lithuania, Luxembourg, Madagascar, Malawi, Malaysia, Maldives, Mali, Malta, Mauritania, Mauritius, Mexico, Moldova, Monaco, Mongolia, Montenegro, Morocco, Mozambique, Myanmar, Namibia, Nepal, Netherlands, New Zealand, Nicaragua, Niger, Nigeria, North Macedonia, Norway, Oman, Pakistan, Palestine, Panama, Papua New Guinea, Paraguay, Peru, Philippines, Poland, Portugal, Qatar, Republic of the Congo, Romania, Russia, Rwanda, Saint Kitts and Nevis, Saint Lucia, San Marino, Saudi Arabia, Senegal, Serbia, Seychelles, Sierra Leone, Singapore, Slovakia, Slovenia, Somalia, South Africa, South Korea, South Sudan, Spain, Sri Lanka, Sudan, Suriname, Swaziland, Sweden, Switzerland, Syria, Taiwan, Tajikistan, Tanzania, Thailand, Timor Leste, Togo, Trinidad and Tobago, Tunisia, Turkey, Uganda, Ukraine, United Arab Emirates, United Kingdom, United States, Uruguay, Uzbekistan, Venezuela, Vietnam, Yemen, Zambia, Zimbabwe 


\section{B Descriptive statistics}

\section{B.1 ACLED Models}

Table B.1: Descriptive statistics (ACLED Models)

\begin{tabular}{|c|c|c|c|c|}
\hline Variable name & Mean & $(\mathrm{SD})$ & $\operatorname{Min} \Rightarrow \operatorname{Max}$ & $\mathrm{N}$ \\
\hline Time of policy adoption since first case (in days) & 76.8 & $(70.4)$ & $0 \Rightarrow 231$ & 135 \\
\hline Policy adoption dummy & 0.70 & $(0.46)$ & $0 \Rightarrow 1$ & 135 \\
\hline Length of policy adoption (in days) & 73.4 & $(65.5)$ & $0 \Rightarrow 178$ & 135 \\
\hline Number of events & 142.11 & $(545.58)$ & $0 \Rightarrow 5,757$ & 135 \\
\hline Number of events (per one million population) & 6.16 & $(15.52)$ & $0 \Rightarrow 118.2$ & 135 \\
\hline Democracy score (V-Dem) & 0.47 & $(0.23)$ & $0.02 \Rightarrow 0.89$ & 135 \\
\hline State Capacity & -0.38 & $(0.80)$ & $-2.45 \Rightarrow 159$ & 135 \\
\hline Intrastate Armed Conflict (Historical) & 0.59 & $(0.49)$ & $0 \Rightarrow 1$ & 135 \\
\hline GDP per capita & 13,072 & $(15,338)$ & $661.2 \Rightarrow 116,935$ & 135 \\
\hline GDP Growth & 2.61 & $(3.35)$ & $-10.8 \Rightarrow 9.43$ & 135 \\
\hline Population density & 148.5 & $(236.3)$ & $1.98 \Rightarrow 1,935.9$ & 135 \\
\hline Population aged 70 or older (\%) & 4.15 & $(3.19)$ & $0.53 \Rightarrow 18.49$ & 132 \\
\hline Diabetes prevalence & 7.78 & $(3.82)$ & $0.99 \Rightarrow 17.72$ & 133 \\
\hline Cardiovascular death rate & 279.9 & $(114.6)$ & $79.37 \Rightarrow 724.4$ & 134 \\
\hline
\end{tabular}




\section{B.2 Latent Human Rights Score Models}

Table B.2: Descriptive statistics (Human Rights Models)

\begin{tabular}{|c|c|c|c|c|}
\hline Variable name & Mean & $(\mathrm{SD})$ & $\operatorname{Min} \Rightarrow \operatorname{Max}$ & $\mathrm{N}$ \\
\hline Time of policy adoption since first case (in days) & 83.4 & $(73.2)$ & $0 \Rightarrow 231$ & 182 \\
\hline Policy adoption dummy & 0.66 & $(0.48)$ & $0 \Rightarrow 1$ & 182 \\
\hline Length of policy adoption (in days) & 64.6 & $(63.9)$ & $0 \Rightarrow 178$ & 182 \\
\hline Latent Human Rights Protection Score & 0.78 & $(1,67)$ & $-2.09 \Rightarrow 5.31$ & 182 \\
\hline Democracy score (V-Dem) & 0.54 & $(0.25)$ & $0.02 \Rightarrow 0.9$ & 177 \\
\hline State Capacity & -0.04 & $(1.01)$ & $-2.45 \Rightarrow 2.22$ & 180 \\
\hline Intrastate Armed Conflict (Historical) & 0.47 & $(0.50)$ & $0 \Rightarrow 1$ & 182 \\
\hline GDP per capita & 18,746 & $(19,635)$ & $661.2 \Rightarrow 116,935$ & 179 \\
\hline GDP Growth & 2.70 & $(3.27)$ & $-10.8 \Rightarrow 18.7$ & 181 \\
\hline Population density & 310.6 & $(1552.2)$ & $1.98 \Rightarrow 19347.5$ & 182 \\
\hline Population aged 70 or older (\%) & 5.50 & $(4.26)$ & $0.53 \Rightarrow 18.49$ & 174 \\
\hline Diabetes prevalence & 7.68 & $(3.80)$ & $0.99 \Rightarrow 22.02$ & 179 \\
\hline Cardiovascular death rate & 257.9 & $(118.0)$ & $79.37 \Rightarrow 724.4$ & 177 \\
\hline
\end{tabular}




\section{Robustness Checks to Different Time-to-policy Thresh- olds}

In this Online Appendix, we check the findings to different time-to-policy thresholds. The outcome measure in our survival plots and the Cox Proportional Hazard models rely on counting the number of days from the first COVID-19 confirmed case to the imposition of a stay-at-home order. We acknowledge that a first case might not necessarily lead to an upward trend in the number of cases in the country or may simply reflect greater testing capabilities. To alleviate this concern, we evaluate the robustness of our findings to using different time-topolicy thresholds, namely the 10th COVID-19 confirmed cases in the subsection C.2, the first 100th COVID-19 confirmed cases in the subsection C.3, the 1st COVID-19 confirmed death in the subsection C.4, and the 10th COVID-19 confirmed case in the subsection C.5. The next subsection C.1 summarizes the results of our robustness checks. In brief, they indicate that none of our main findings are sensitive to using a specific time-to-policy threshold. 


\section{C.1 Robustness to varying time-to-policy thresholds (Summary table)}

Table C.1: Cox proportional hazards models of estimating the effect of recent state repression on the timing of policy adoption with varying time-to-policy thresholds

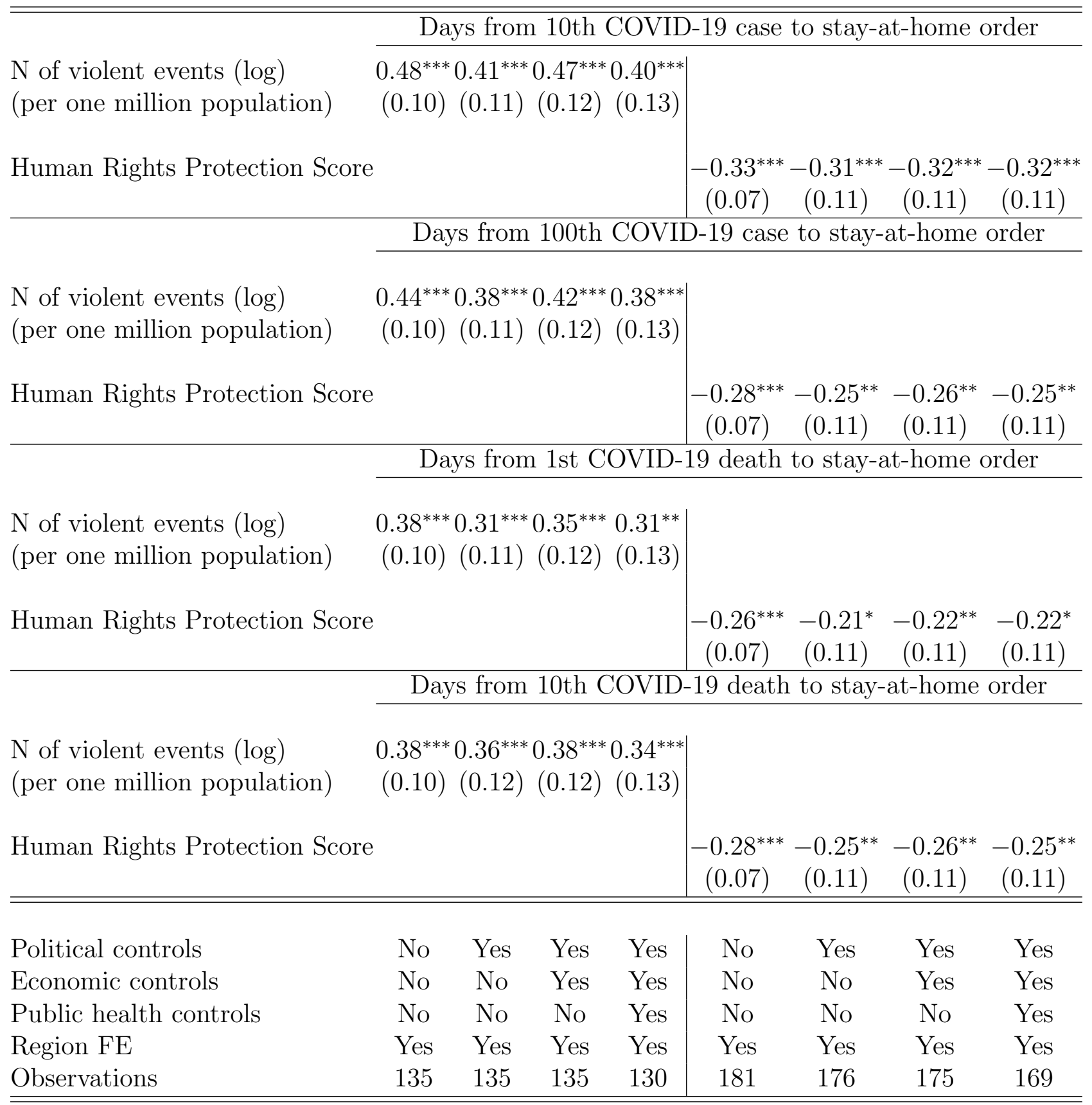

${ }^{*} \mathrm{p}<0.1 ;{ }^{* *} \mathrm{p}<0.05 ;{ }^{* * *} \mathrm{p}<0.01$. SE in parenthesis. Region-FE include: Africa, Asia, Europe, North America, and South America. See full models in the following Appendices. 


\section{C.2 Time to policy after the 10th confirmed COVID-19 case}

Table C.2: Cox proportional hazards models of estimating the effect of state repression in 2019 and human rights scores on the time to adopting a stay-at-home order (10th confirmed case)

\begin{tabular}{|c|c|c|c|c|c|c|c|c|}
\hline & \multicolumn{8}{|c|}{ Days from 10th COVID-19 confirmed case to stay-at-home order } \\
\hline & $(1)$ & $(2)$ & $(3)$ & $(4)$ & $(5)$ & $(6)$ & $(7)$ & $(8)$ \\
\hline $\begin{array}{l}\mathrm{N} \text { of violent events }(\mathrm{log}) \\
\text { (per one million population) }\end{array}$ & $\begin{array}{c}0.48^{* * *} \\
(0.10)\end{array}$ & $\begin{array}{c}0.41^{* * *} \\
(0.11)\end{array}$ & $\begin{array}{c}0.47^{* * *} \\
(0.12)\end{array}$ & $\begin{array}{c}0.40^{* * *} \\
(0.13)\end{array}$ & & & & \\
\hline Human Rights Protection Score & & & & & $\begin{array}{c}-0.33^{* * *} \\
(0.07)\end{array}$ & $\begin{array}{c}-0.31^{* * *} \\
(0.11)\end{array}$ & $\begin{array}{c}-0.32^{* * *} \\
(0.11)\end{array}$ & $\begin{array}{c}-0.32^{* * *} \\
(0.11)\end{array}$ \\
\hline Democracy score (V-Dem) & & $\begin{array}{l}-0.04 \\
(0.60)\end{array}$ & $\begin{array}{l}0.29 \\
(0.63)\end{array}$ & $\begin{array}{l}1.15 \\
(0.73)\end{array}$ & & $\begin{array}{c}0.68 \\
(0.60)\end{array}$ & $\begin{array}{l}1.15^{*} \\
(0.63)\end{array}$ & $\begin{array}{c}1.97^{* * *} \\
(0.72)\end{array}$ \\
\hline State Capacity & & $\begin{array}{l}-0.28 \\
(0.20)\end{array}$ & $\begin{array}{c}-0.65^{* * *} \\
(0.25)\end{array}$ & $\begin{array}{l}-0.37 \\
(0.28)\end{array}$ & & $\begin{array}{c}-0.33^{* *} \\
(0.17)\end{array}$ & $\begin{array}{c}-0.64^{* * *} \\
(0.21)\end{array}$ & $\begin{array}{c}-0.45^{*} \\
(0.23)\end{array}$ \\
\hline $\begin{array}{l}\text { Intrastate Armed Conflict } \\
\text { (Historical) }\end{array}$ & & $\begin{array}{l}-0.01 \\
(0.25)\end{array}$ & $\begin{array}{l}0.11 \\
(0.25)\end{array}$ & $\begin{array}{c}0.22 \\
(0.26)\end{array}$ & & $\begin{array}{c}0.07 \\
(0.24)\end{array}$ & $\begin{array}{c}0.16 \\
(0.24)\end{array}$ & $\begin{array}{l}0.20 \\
(0.25)\end{array}$ \\
\hline GDP per capita (log) & & & $\begin{array}{l}0.42^{* *} \\
(0.18)\end{array}$ & $\begin{array}{l}0.37^{*} \\
(0.21)\end{array}$ & & & $\begin{array}{l}0.33^{* *} \\
(0.16)\end{array}$ & $\begin{array}{c}0.21 \\
(0.18)\end{array}$ \\
\hline GDP Annual Growth & & & $\begin{array}{l}0.03 \\
(0.04)\end{array}$ & $\begin{array}{l}-0.01 \\
(0.04)\end{array}$ & & & $\begin{array}{l}-0.01 \\
(0.03)\end{array}$ & $\begin{array}{l}-0.03 \\
(0.03)\end{array}$ \\
\hline Population Density ('000) & & & $\begin{array}{c}0.46 \\
(0.46)\end{array}$ & $\begin{array}{c}0.70 \\
(0.46)\end{array}$ & & & $\begin{array}{c}0.22 \\
(0.14)\end{array}$ & $\begin{array}{c}0.22 \\
(0.14)\end{array}$ \\
\hline $\begin{array}{l}\text { Population aged } 70 \\
\text { or older (percentage) }\end{array}$ & & & & $\begin{array}{c}-0.13^{*} \\
(0.07)\end{array}$ & & & & $\begin{array}{l}-0.03 \\
(0.06)\end{array}$ \\
\hline Diabetes prevalence & & & & $\begin{array}{c}0.04 \\
(0.04)\end{array}$ & & & & $\begin{array}{c}0.09^{* * *} \\
(0.03)\end{array}$ \\
\hline Cardiovascular death rate & & & & $\begin{array}{l}0.002^{* *} \\
(0.001)\end{array}$ & & & & $\begin{array}{c}0.001 \\
(0.001)\end{array}$ \\
\hline Region FE & Yes & Yes & Yes & Yes & Yes & Yes & Yes & Yes \\
\hline Observations & 135 & 135 & 135 & 130 & 182 & 177 & 176 & 170 \\
\hline
\end{tabular}

${ }^{*} \mathrm{p}<0.1 ;{ }^{* *} \mathrm{p}<0.05 ;{ }^{* * *} \mathrm{p}<0.01$. Standard errors in parenthesis. Region-Fixed Effects include:

Africa, Asia, Europe, North America, South America, and Oceania. 


\section{C.3 Time to policy after the 100th confirmed COVID-19 case}

Table C.3: Cox proportional hazards models of estimating the effect of state repression in 2019 and human rights scores on the time to adopting a stay-at-home order (100th confirmed case)

\begin{tabular}{|c|c|c|c|c|c|c|c|c|}
\hline & \multicolumn{8}{|c|}{ Days from 100th COVID-19 confirmed case to stay-at-home order } \\
\hline & $(1)$ & $(2)$ & $(3)$ & $(4)$ & $(5)$ & $(6)$ & $(7)$ & $(8)$ \\
\hline $\begin{array}{l}\mathrm{N} \text { of violent events }(\mathrm{log}) \\
\text { (per one million population) }\end{array}$ & $\begin{array}{c}0.44^{* * *} \\
(0.10)\end{array}$ & $\begin{array}{l}0.38^{* * *} \\
(0.11)\end{array}$ & $\begin{array}{c}0.42^{* * *} \\
(0.12)\end{array}$ & $\begin{array}{c}0.38^{* * *} \\
(0.13)\end{array}$ & & & & \\
\hline Human Rights Protection Score & & & & & $\begin{array}{c}-0.28^{* * *} \\
(0.07)\end{array}$ & $\begin{array}{c}-0.25^{* *} \\
(0.11)\end{array}$ & $\begin{array}{c}-0.26^{* *} \\
(0.11)\end{array}$ & $\begin{array}{c}-0.25^{* *} \\
(0.11)\end{array}$ \\
\hline Democracy score (V-Dem) & & $\begin{array}{c}-0.002 \\
(0.59)\end{array}$ & $\begin{array}{c}0.31 \\
(0.63)\end{array}$ & $\begin{array}{l}1.19 \\
(0.73)\end{array}$ & & $\begin{array}{c}0.65 \\
(0.61)\end{array}$ & $\begin{array}{l}1.04^{*} \\
(0.63)\end{array}$ & $\begin{array}{l}1.85^{* * *} \\
(0.71)\end{array}$ \\
\hline State Capacity & & $\begin{array}{l}-0.21 \\
(0.20)\end{array}$ & $\begin{array}{c}-0.53^{* *} \\
(0.26)\end{array}$ & $\begin{array}{l}-0.26 \\
(0.29)\end{array}$ & & $\begin{array}{c}-0.37^{* *} \\
(0.17)\end{array}$ & $\begin{array}{c}-0.65^{* * *} \\
(0.22)\end{array}$ & $\begin{array}{c}-0.42^{*} \\
(0.25)\end{array}$ \\
\hline $\begin{array}{l}\text { Intrastate Armed Conflict } \\
\text { (Historical) }\end{array}$ & & $\begin{array}{l}-0.02 \\
(0.24)\end{array}$ & $\begin{array}{c}0.08 \\
(0.25)\end{array}$ & $\begin{array}{c}0.15 \\
(0.25)\end{array}$ & & $\begin{array}{l}-0.02 \\
(0.23)\end{array}$ & $\begin{array}{c}0.07 \\
(0.24)\end{array}$ & $\begin{array}{c}0.07 \\
(0.24)\end{array}$ \\
\hline GDP per capita $(\log )$ & & & $\begin{array}{l}0.34^{*} \\
(0.17)\end{array}$ & $\begin{array}{c}0.27 \\
(0.21)\end{array}$ & & & $\begin{array}{l}0.28^{*} \\
(0.17)\end{array}$ & $\begin{array}{c}0.12 \\
(0.19)\end{array}$ \\
\hline GDP Annual Growth & & & $\begin{array}{c}0.02 \\
(0.04)\end{array}$ & $\begin{array}{l}-0.01 \\
(0.04)\end{array}$ & & & $\begin{array}{c}0.0000 \\
(0.03)\end{array}$ & $\begin{array}{l}-0.02 \\
(0.03)\end{array}$ \\
\hline Population Density ('000) & & & $\begin{array}{c}0.39 \\
(0.43)\end{array}$ & $\begin{array}{c}0.57 \\
(0.43)\end{array}$ & & & $\begin{array}{l}0.18 \\
(0.14)\end{array}$ & $\begin{array}{c}0.16 \\
(0.14)\end{array}$ \\
\hline $\begin{array}{l}\text { Population aged } 70 \\
\text { or older (percentage) }\end{array}$ & & & & $\begin{array}{l}-0.11 \\
(0.07)\end{array}$ & & & & $\begin{array}{l}-0.04 \\
(0.06)\end{array}$ \\
\hline Diabetes prevalence & & & & $\begin{array}{c}0.05 \\
(0.04)\end{array}$ & & & & $\begin{array}{c}0.10^{* * *} \\
(0.03)\end{array}$ \\
\hline Cardiovascular death rate & & & & $\begin{array}{l}0.003^{* *} \\
(0.001)\end{array}$ & & & & $\begin{array}{c}0.001 \\
(0.001)\end{array}$ \\
\hline Region FE & Yes & Yes & Yes & Yes & Yes & Yes & Yes & Yes \\
\hline Observations & 135 & 135 & 135 & 130 & 181 & 176 & 175 & 169 \\
\hline
\end{tabular}

${ }^{*} \mathrm{p}<0.1 ;{ }^{* *} \mathrm{p}<0.05 ;{ }^{* *} \mathrm{p}<0.01$. Standard errors in parenthesis. Region-Fixed Effects include:

Africa, Asia, Europe, North America, South America, and Oceania. 


\section{C.4 Time to policy after the 1st confirmed COVID-19 death}

Table C.4: Cox proportional hazards models of estimating the effect of state repression in 2019 and human rights scores on the time to adopting a stay-at-home order (1st death)

\begin{tabular}{|c|c|c|c|c|c|c|c|c|}
\hline & \multicolumn{8}{|c|}{ Days from 1st COVID-19 confirmed death to stay-at-home ordel } \\
\hline & $(1)$ & $(2)$ & (3) & $(4)$ & (5) & (6) & $(7)$ & (8) \\
\hline $\begin{array}{l}\mathrm{N} \text { of violent events }(\log ) \\
\text { (per one million population) }\end{array}$ & $\begin{array}{r}0.38^{* * *} \\
(0.10)\end{array}$ & $\begin{array}{c}0.31^{* * *} \\
(0.11)\end{array}$ & $\begin{array}{c}0.35^{* * *} \\
(0.12)\end{array}$ & $\begin{array}{l}0.31^{* *} \\
(0.13)\end{array}$ & & & & \\
\hline Human Rights Protection Score & & & & & $\begin{array}{l}-0.26^{* * *} \\
(0.07)\end{array}$ & $\begin{array}{l}-0.21^{*} \\
(0.11)\end{array}$ & $\begin{array}{c}-0.22^{* *} \\
(0.11)\end{array}$ & $\begin{array}{r}-0.22^{*} \\
(0.11)\end{array}$ \\
\hline Democracy score (V-Dem) & & $\begin{array}{l}-0.07 \\
(0.60)\end{array}$ & $\begin{array}{c}0.19 \\
(0.63)\end{array}$ & $\begin{array}{c}1.04 \\
(0.74)\end{array}$ & & $\begin{array}{c}0.41 \\
(0.61)\end{array}$ & $\begin{array}{c}0.78 \\
(0.64)\end{array}$ & $\begin{array}{l}1.51^{* *} \\
(0.72)\end{array}$ \\
\hline State Capacity & & $\begin{array}{l}-0.23 \\
(0.20)\end{array}$ & $\begin{array}{c}-0.52^{* *} \\
(0.25)\end{array}$ & $\begin{array}{l}-0.27 \\
(0.28)\end{array}$ & & $\begin{array}{c}-0.35^{* *} \\
(0.17)\end{array}$ & $\begin{array}{c}-0.61^{* * *} \\
(0.22)\end{array}$ & $\begin{array}{l}-0.39 \\
(0.24)\end{array}$ \\
\hline $\begin{array}{l}\text { Intrastate Armed Conflict } \\
\text { (Historical) }\end{array}$ & & $\begin{array}{c}0.04 \\
(0.25)\end{array}$ & $\begin{array}{c}0.11 \\
(0.25)\end{array}$ & $\begin{array}{c}0.19 \\
(0.25)\end{array}$ & & $\begin{array}{c}-0.003 \\
(0.24)\end{array}$ & $\begin{array}{l}0.07 \\
(0.24)\end{array}$ & $\begin{array}{c}0.10 \\
(0.25)\end{array}$ \\
\hline GDP per capita $(\log )$ & & & $\begin{array}{l}0.32^{*} \\
(0.17)\end{array}$ & $\begin{array}{c}0.27 \\
(0.21)\end{array}$ & & & $\begin{array}{l}0.28^{*} \\
(0.16)\end{array}$ & $\begin{array}{c}0.14 \\
(0.19)\end{array}$ \\
\hline GDP Annual Growth & & & $\begin{array}{c}0.02 \\
(0.04)\end{array}$ & $\begin{array}{l}-0.02 \\
(0.04)\end{array}$ & & & $\begin{array}{l}0.003 \\
(0.03)\end{array}$ & $\begin{array}{l}-0.01 \\
(0.03)\end{array}$ \\
\hline Population Density ('000) & & & $\begin{array}{c}0.28 \\
(0.47)\end{array}$ & $\begin{array}{c}0.44 \\
(0.47)\end{array}$ & & & $\begin{array}{c}0.17 \\
(0.15)\end{array}$ & $\begin{array}{c}0.14 \\
(0.15)\end{array}$ \\
\hline $\begin{array}{l}\text { Population aged } 70 \\
\text { or older (percentage) }\end{array}$ & & & & $\begin{array}{l}-0.11 \\
(0.07)\end{array}$ & & & & $\begin{array}{l}-0.03 \\
(0.06)\end{array}$ \\
\hline Diabetes prevalence & & & & $\begin{array}{c}0.04 \\
(0.04)\end{array}$ & & & & $\begin{array}{r}0.09^{* * *} \\
(0.03)\end{array}$ \\
\hline Cardiovascular death rate & & & & $\begin{array}{c}0.002 \\
(0.001)\end{array}$ & & & & $\begin{array}{c}0.001 \\
(0.001)\end{array}$ \\
\hline & Yes & Yes & Yes & Yes & Yes & Yes & Yes & Yes \\
\hline Observations & 135 & 135 & 135 & 130 & 181 & 176 & 175 & 169 \\
\hline
\end{tabular}

${ }^{*} \mathrm{p}<0.1 ;{ }^{* *} \mathrm{p}<0.05 ;{ }^{* * *} \mathrm{p}<0.01$. Standard errors in parenthesis. Region-Fixed Effects include:

Africa, Asia, Europe, North America, South America, and Oceania. 


\section{C.5 Time to policy after the 10th confirmed COVID-19 death}

Table C.5: Cox proportional hazards models of estimating the effect of state repression in 2019 and human rights scores on the time to adopting a stay-at-home order (10th death)

\begin{tabular}{|c|c|c|c|c|c|c|c|c|}
\hline & \multicolumn{8}{|c|}{ Days from 10th COVID-19 confirmed death to stay-at-home order } \\
\hline & $(1)$ & $(2)$ & $(3)$ & $(4)$ & $(5)$ & (6) & $(7)$ & $(8)$ \\
\hline $\begin{array}{l}\mathrm{N} \text { of violent events }(\mathrm{log}) \\
\text { (per one million population) }\end{array}$ & $\begin{array}{c}0.38^{* * *} \\
(0.10)\end{array}$ & $\begin{array}{c}0.36^{* * *} \\
(0.12)\end{array}$ & $\begin{array}{c}0.38^{* * *} \\
(0.12)\end{array}$ & $\begin{array}{c}0.34^{* * *} \\
(0.13)\end{array}$ & & & & \\
\hline Human Rights Protection Score & & & & & $\begin{array}{c}-0.28^{* * *} \\
(0.07)\end{array}$ & $\begin{array}{c}-0.25^{* *} \\
(0.11)\end{array}$ & $\begin{array}{c}-0.26^{* *} \\
(0.11)\end{array}$ & $\begin{array}{c}-0.25^{* *} \\
(0.11)\end{array}$ \\
\hline Democracy score (V-Dem) & & $\begin{array}{l}-0.12 \\
(0.61)\end{array}$ & $\begin{array}{c}0.22 \\
(0.64)\end{array}$ & $\begin{array}{c}1.09 \\
(0.74)\end{array}$ & & $\begin{array}{c}0.67 \\
(0.62)\end{array}$ & $\begin{array}{l}1.13^{*} \\
(0.65)\end{array}$ & $\begin{array}{l}1.57^{* *} \\
(0.70)\end{array}$ \\
\hline State Capacity & & $\begin{array}{l}-0.07 \\
(0.20)\end{array}$ & $\begin{array}{l}-0.39 \\
(0.26)\end{array}$ & $\begin{array}{l}-0.07 \\
(0.30)\end{array}$ & & $\begin{array}{l}-0.17 \\
(0.17)\end{array}$ & $\begin{array}{c}-0.47^{* *} \\
(0.22)\end{array}$ & $\begin{array}{l}-0.28 \\
(0.24)\end{array}$ \\
\hline $\begin{array}{l}\text { Intrastate Armed Conflict } \\
\text { (Historical) }\end{array}$ & & $\begin{array}{l}-0.04 \\
(0.24)\end{array}$ & $\begin{array}{c}0.05 \\
(0.25)\end{array}$ & $\begin{array}{c}0.10 \\
(0.25)\end{array}$ & & $\begin{array}{l}-0.06 \\
(0.24)\end{array}$ & $\begin{array}{c}0.02 \\
(0.24)\end{array}$ & $\begin{array}{l}-0.01 \\
(0.24)\end{array}$ \\
\hline GDP per capita (log) & & & $\begin{array}{l}0.30^{*} \\
(0.17)\end{array}$ & $\begin{array}{c}0.21 \\
(0.21)\end{array}$ & & & $\begin{array}{l}0.29^{*} \\
(0.16)\end{array}$ & $\begin{array}{c}0.13 \\
(0.19)\end{array}$ \\
\hline GDP Annual Growth & & & $\begin{array}{c}0.01 \\
(0.04)\end{array}$ & $\begin{array}{l}-0.02 \\
(0.04)\end{array}$ & & & $\begin{array}{c}-0.003 \\
(0.03)\end{array}$ & $\begin{array}{l}-0.02 \\
(0.03)\end{array}$ \\
\hline Population Density ('000) & & & $\begin{array}{c}0.69 \\
(0.47)\end{array}$ & $\begin{array}{l}0.81^{*} \\
(0.46)\end{array}$ & & & $\begin{array}{l}0.27^{*} \\
(0.14)\end{array}$ & $\begin{array}{l}0.24^{*} \\
(0.14)\end{array}$ \\
\hline $\begin{array}{l}\text { Population aged } 70 \\
\text { or older (percentage) }\end{array}$ & & & & $\begin{array}{c}-0.13^{*} \\
(0.07)\end{array}$ & & & & $\begin{array}{l}-0.04 \\
(0.06)\end{array}$ \\
\hline Diabetes prevalence & & & & $\begin{array}{l}0.05 \\
(0.04)\end{array}$ & & & & $\begin{array}{l}0.08^{* *} \\
(0.03)\end{array}$ \\
\hline Cardiovascular death rate & & & & $\begin{array}{l}0.002^{*} \\
(0.001)\end{array}$ & & & & $\begin{array}{l}0.0005 \\
(0.001)\end{array}$ \\
\hline Region FE & Yes & Yes & Yes & Yes & Yes & Yes & Yes & Yes \\
\hline Observations & 135 & 135 & 135 & 130 & 181 & 176 & 175 & 169 \\
\hline
\end{tabular}

${ }^{*} \mathrm{p}<0.1 ;{ }^{* *} \mathrm{p}<0.05 ;{ }^{* * *} \mathrm{p}<0.01$. Standard errors in parenthesis. Region-Fixed Effects include:

Africa, Asia, Europe, North America, South America, and Oceania. 


\section{Robustness to Measuring Violence using a Different Time Window}

In this Appendix, we evaluate the robustness of our findings to the time windows used to measure violence against civilians before the outbreak in the ACLED models. For our main ACLED models, we measure a governments' recent record of violence using the number of violent events against civilians in 2019. However, it may be more precise to only measure violence that took place immediately before the pandemic outbreak. Indeed, using all of 2019, rather than the last six months is an arbitrary decision. Hence, in this Online Appendix, we examine the robustness of our findings using different time windows for building that measure. We evaluate our findings when using the last semester of 2019 as the time window to build our indicator of state repression against civilians. Because the specific period to build our measure is rather arbitrary, we re-evaluate the findings of our three hypotheses to using the six months preceding the first confirmed global case - July through December of 2019 - in our measure of violence against civilians:

- For a re-evaluation of Hypothesis 1, see Appendix D.1.

- For a re-evaluation of Hypothesis 2, see Appendix D.2.

- For a re-evaluation of Hypothesis 3, see Appendix D.3.

These models show that our main findings remain substantively unaltered with regards to our hypotheses when using the last semester of 2019 - rather than the entire year of 2019 - as the time window to measure state-led violence against civilians. Note also that this robustness check is irrelevant for our models based on the latent human rights protection scores. 
D.1 Re-evaluating Hypothesis 1 using the last semester of 2019 to measure violence against civilians 
Table D.1: Logistic regressions on the effect of recent state repression on adopting stay-athome orders

\begin{tabular}{|c|c|c|c|c|}
\hline & \multicolumn{4}{|c|}{ Adoption of a stay-at-home order } \\
\hline & (1) & (2) & (3) & (4) \\
\hline $\begin{array}{l}\mathrm{N} \text { of violent events }(\mathrm{log}) \\
\text { (per one million population) }\end{array}$ & $\begin{array}{c}0.81^{* * *} \\
(0.30)\end{array}$ & $\begin{array}{l}0.69^{* *} \\
(0.32)\end{array}$ & $\begin{array}{l}0.83^{* *} \\
(0.34)\end{array}$ & $\begin{array}{l}0.78^{* *} \\
(0.39)\end{array}$ \\
\hline Democracy score (V-Dem) & & $\begin{array}{l}-0.65 \\
(1.12)\end{array}$ & $\begin{array}{c}0.09 \\
(1.19)\end{array}$ & $\begin{array}{c}1.70 \\
(1.49)\end{array}$ \\
\hline State Capacity & & $\begin{array}{l}-0.04 \\
(0.36)\end{array}$ & $\begin{array}{l}-0.80 \\
(0.53)\end{array}$ & $\begin{array}{c}0.08 \\
(0.60)\end{array}$ \\
\hline $\begin{array}{l}\text { Intrastate Armed Conflict } \\
\text { (Historical) }\end{array}$ & & $\begin{array}{c}0.44 \\
(0.45)\end{array}$ & $\begin{array}{c}0.59 \\
(0.47)\end{array}$ & $\begin{array}{c}0.80 \\
(0.52)\end{array}$ \\
\hline GDP per capita $(\log )$ & & & $\begin{array}{l}0.83^{* *} \\
(0.40)\end{array}$ & $\begin{array}{l}0.79^{*} \\
(0.47)\end{array}$ \\
\hline GDP annual growth & & & $\begin{array}{c}0.03 \\
(0.07)\end{array}$ & $\begin{array}{l}-0.01 \\
(0.08)\end{array}$ \\
\hline Population Density ('000) & & & $\begin{array}{c}0.88 \\
(1.15)\end{array}$ & $\begin{array}{c}2.84 \\
(2.01)\end{array}$ \\
\hline $\begin{array}{l}\text { Population aged } 70 \text { or older } \\
\text { (percentage) }\end{array}$ & & & & $\begin{array}{c}-0.38^{* *} \\
(0.17)\end{array}$ \\
\hline Diabetes prevalence & & & & $\begin{array}{c}0.16 \\
(0.11)\end{array}$ \\
\hline Cardiovascular death rate & & & & $\begin{array}{c}0.01^{* *} \\
(0.003)\end{array}$ \\
\hline Constant & $\begin{array}{l}-0.04 \\
(0.34)\end{array}$ & $\begin{array}{l}-0.02 \\
(0.75)\end{array}$ & $\begin{array}{c}-7.90^{* *} \\
(3.94)\end{array}$ & $\begin{array}{l}-9.65^{* *} \\
(4.46)\end{array}$ \\
\hline Region FE & Yes & Yes & Yes & Yes \\
\hline Observations & 135 & 135 & 135 & 130 \\
\hline
\end{tabular}

${ }^{*} \mathrm{p}<0.1 ;{ }^{* *} \mathrm{p}<0.05 ;{ }^{* * *} \mathrm{p}<0.01$. Standard errors in parenthesis. Region-Fixed Effects include: Africa, Asia, Europe, North America, and South America. 15 
D.2 Re-evaluating Hypothesis 2 using the last semester of 2019 to measure violence against civilians 
Table D.2: Cox proportional hazards models of estimating the effect of recent state repression in the last three months of 2019 on the time to adopting a stay-at-home order

\begin{tabular}{|c|c|c|c|c|}
\hline & \multicolumn{4}{|c|}{ Days from first case to policy } \\
\hline & $(1)$ & $(2)$ & $(3)$ & $(4)$ \\
\hline $\begin{array}{l}\mathrm{N} \text { of violent events (log) } \\
\text { (per one million population) }\end{array}$ & $\begin{array}{c}0.56^{* * *} \\
(0.12)\end{array}$ & $\begin{array}{c}0.49^{* * *} \\
(0.13)\end{array}$ & $\begin{array}{c}0.57^{* * *} \\
(0.14)\end{array}$ & $\begin{array}{c}0.52^{* * *} \\
(0.15)\end{array}$ \\
\hline Democracy score (V-Dem) & & $\begin{array}{l}-0.22 \\
(0.59)\end{array}$ & $\begin{array}{c}0.15 \\
(0.62)\end{array}$ & $\begin{array}{c}0.92 \\
(0.72)\end{array}$ \\
\hline State Capacity & & $\begin{array}{l}-0.26 \\
(0.20)\end{array}$ & $\begin{array}{c}-0.72^{* * *} \\
(0.26)\end{array}$ & $\begin{array}{l}-0.42 \\
(0.29)\end{array}$ \\
\hline $\begin{array}{l}\text { Intrastate Armed Conflict } \\
\text { (Historical) }\end{array}$ & & $\begin{array}{l}-0.04 \\
(0.25)\end{array}$ & $\begin{array}{c}0.09 \\
(0.25)\end{array}$ & $\begin{array}{c}0.20 \\
(0.26)\end{array}$ \\
\hline GDP per capita (log) & & & $\begin{array}{c}0.49^{* * *} \\
(0.18)\end{array}$ & $\begin{array}{l}0.45^{* *} \\
(0.22)\end{array}$ \\
\hline GDP annual growth & & & $\begin{array}{c}0.03 \\
(0.04)\end{array}$ & $\begin{array}{l}-0.01 \\
(0.04)\end{array}$ \\
\hline Population Density ('000) & & & $\begin{array}{c}0.46 \\
(0.46)\end{array}$ & $\begin{array}{c}0.70 \\
(0.46)\end{array}$ \\
\hline $\begin{array}{l}\text { Population aged } 70 \text { or older } \\
\text { (percentage) }\end{array}$ & & & & $\begin{array}{l}-0.12 \\
(0.07)\end{array}$ \\
\hline Diabetes prevalence & & & & $\begin{array}{c}0.02 \\
(0.04)\end{array}$ \\
\hline Cardiovascular death rate & & & & $\begin{array}{l}0.002^{*} \\
(0.001)\end{array}$ \\
\hline Region FE & Yes & Yes & Yes & Yes \\
\hline $\mathrm{N}$ countries & 135 & 135 & 135 & 130 \\
\hline
\end{tabular}

${ }^{*} \mathrm{p}<0.1 ;{ }^{* *} \mathrm{p}<0.05 ;{ }^{* *} \mathrm{p}<0.01$. Positive coefficients in the Cox $\mathrm{PH}$ indicate that policies are expected to be adopted earlier. RegionFixed Effects include: Africa, Asia, Europe, North America, and South America. 
D.3 Re-evaluating Hypothesis 3 using the last semester of 2019 to measure violence against civilians 
Table D.3: OLS regressions on the effect of recent repression on the length of stay-at-home orders

\begin{tabular}{|c|c|c|c|c|}
\hline & \multicolumn{4}{|c|}{ Number of days with a policy $(\log )$} \\
\hline & $(1)$ & $(2)$ & $(3)$ & $(4)$ \\
\hline $\begin{array}{l}\mathrm{N} \text { of violent events }(\mathrm{log}) \\
\text { (per one million population) }\end{array}$ & $\begin{array}{c}0.69^{* * *} \\
(0.22)\end{array}$ & $\begin{array}{l}0.53^{* *} \\
(0.25)\end{array}$ & $\begin{array}{l}0.59^{* *} \\
(0.24)\end{array}$ & $\begin{array}{l}0.59^{* *} \\
(0.25)\end{array}$ \\
\hline Democracy score (V-Dem) & & $\begin{array}{l}-0.57 \\
(1.19)\end{array}$ & $\begin{array}{l}-0.06 \\
(1.25)\end{array}$ & $\begin{array}{l}1.06 \\
(1.23)\end{array}$ \\
\hline State capacity & & $\begin{array}{l}-0.22 \\
(0.31)\end{array}$ & $\begin{array}{l}-0.68 \\
(0.41)\end{array}$ & $\begin{array}{l}-0.17 \\
(0.40)\end{array}$ \\
\hline $\begin{array}{l}\text { Intrastate Armed Conflict } \\
\text { (Historical) }\end{array}$ & & $\begin{array}{c}0.34 \\
(0.41)\end{array}$ & $\begin{array}{c}0.42 \\
(0.43)\end{array}$ & $\begin{array}{c}0.57 \\
(0.43)\end{array}$ \\
\hline GDP per capita $(\log )$ & & & $\begin{array}{l}0.54^{*} \\
(0.31)\end{array}$ & $\begin{array}{c}0.48 \\
(0.37)\end{array}$ \\
\hline GDP annual growth & & & $\begin{array}{c}-0.0003 \\
(0.06)\end{array}$ & $\begin{array}{l}-0.03 \\
(0.06)\end{array}$ \\
\hline Population Density ('000) & & & $\begin{array}{c}0.33 \\
(0.71)\end{array}$ & $\begin{array}{c}0.75 \\
(1.21)\end{array}$ \\
\hline $\begin{array}{l}\text { Population aged } 70 \text { or older } \\
\text { (percentage) }\end{array}$ & & & & $\begin{array}{c}-0.24^{* * *} \\
(0.09)\end{array}$ \\
\hline Diabetes prevalence & & & & $\begin{array}{c}0.06 \\
(0.07)\end{array}$ \\
\hline Cardiovascular death rate & & & & $\begin{array}{c}0.003^{*} \\
(0.002)\end{array}$ \\
\hline Constant & $\begin{array}{c}2.18^{* * *} \\
(0.34)\end{array}$ & $\begin{array}{c}2.09^{* * *} \\
(0.74)\end{array}$ & $\begin{array}{l}-2.97 \\
(2.99)\end{array}$ & $\begin{array}{l}-3.33 \\
(3.44)\end{array}$ \\
\hline Region FE & Yes & Yes & Yes & Yes \\
\hline Observations & 135 & 135 & 135 & 130 \\
\hline
\end{tabular}

${ }^{*} \mathrm{p}<0.1 ;{ }^{* *} \mathrm{p}<0.05 ;{ }^{* * *} \mathrm{p}<0.01$. Robust standard errors in parenthesis. Region-Fixed Effects include: Africa, Asia, Europe, North America, and South Amertea. 


\section{E Robustness Checks to Using All Violence Against Civilians}

Our measure of Violence against Civilians from ACLED excludes violent events perpetrated by political organizations that aim at countering the established governing regimes (i.e., rebel groups), or violence that arises from civilians themselves (e.g., riots and protests). Given the methodological difficulties of accurately identifying the perpetrators of violence, we now evaluate whether these decisions affect our findings. To do this, in online Appendix E, we report the main findings using all Violence Against Civilians in the ACLED Dataset, i.e., removing any actor-related filters. When using All Violence Against Civilians as a measure of pre-outbreak domestic conflict, Tables E.1, E.2, and E.3 show that our main hypotheses remain substantively unaltered. 
E.1 Re-evaluating Hypothesis 1 Using All Violence Against Civilians 
Table E.1: Logistic regressions on the effect of recent state repression on adopting stay-athome orders

\begin{tabular}{|c|c|c|c|c|}
\hline & \multicolumn{4}{|c|}{ Adoption of a stay-at-home order } \\
\hline & $(1)$ & $(2)$ & $(3)$ & $(4)$ \\
\hline $\begin{array}{l}\mathrm{N} \text { of violent events }(\mathrm{log}) \\
\text { (per one million population) }\end{array}$ & $\begin{array}{l}0.53^{* *} \\
(0.21)\end{array}$ & $\begin{array}{l}0.44^{*} \\
(0.23)\end{array}$ & $\begin{array}{l}0.54^{* *} \\
(0.24)\end{array}$ & $\begin{array}{l}0.49^{*} \\
(0.26)\end{array}$ \\
\hline Democracy score (V-Dem) & & $\begin{array}{l}-0.73 \\
(1.12)\end{array}$ & $\begin{array}{l}-0.07 \\
(1.18)\end{array}$ & $\begin{array}{l}1.38 \\
(1.42)\end{array}$ \\
\hline State Capacity & & $\begin{array}{c}0.01 \\
(0.37)\end{array}$ & $\begin{array}{l}-0.70 \\
(0.52)\end{array}$ & $\begin{array}{c}0.12 \\
(0.59)\end{array}$ \\
\hline $\begin{array}{l}\text { Intrastate Armed Conflict } \\
\text { (Historical) }\end{array}$ & & $\begin{array}{c}0.47 \\
(0.45)\end{array}$ & $\begin{array}{c}0.61 \\
(0.47)\end{array}$ & $\begin{array}{l}0.87^{*} \\
(0.52)\end{array}$ \\
\hline GDP per capita (log) & & & $\begin{array}{l}0.80^{* *} \\
(0.40)\end{array}$ & $\begin{array}{c}0.63 \\
(0.45)\end{array}$ \\
\hline GDP Annual Growth & & & $\begin{array}{c}0.03 \\
(0.07)\end{array}$ & $\begin{array}{c}-0.001 \\
(0.08)\end{array}$ \\
\hline Population Density ('000) & & & $\begin{array}{c}0.84 \\
(1.16)\end{array}$ & $\begin{array}{c}1.90 \\
(1.69)\end{array}$ \\
\hline $\begin{array}{l}\text { Population aged } 70 \\
\text { or older (percentage) }\end{array}$ & & & & $\begin{array}{c}-0.31^{* *} \\
(0.14)\end{array}$ \\
\hline Diabetes prevalence & & & & $\begin{array}{l}0.20^{*} \\
(0.11)\end{array}$ \\
\hline Cardiovascular death rate & & & & $\begin{array}{c}0.01^{* *} \\
(0.003)\end{array}$ \\
\hline Constant & $\begin{array}{l}-0.15 \\
(0.37)\end{array}$ & $\begin{array}{l}-0.05 \\
(0.75)\end{array}$ & $\begin{array}{l}-7.61^{* *} \\
(3.87)\end{array}$ & $\begin{array}{c}-8.85^{* *} \\
(4.32)\end{array}$ \\
\hline Region FE & Yes & Yes & Yes & Yes \\
\hline Observations & 135 & 135 & 135 & 135 \\
\hline
\end{tabular}

${ }^{*} \mathrm{p}<0.1 ;{ }^{* *} \mathrm{p}<0.05 ;{ }^{* * *} \mathrm{p}<0.01$ andard errors in parenthesis. Region-Fixed Effects include: Africa, Asia, Europe, North America, and South America. 
E.2 Re-evaluating Hypothesis 2 Using All Violence Against Civilians 
Table E.2: Cox proportional hazards models of estimating the effect of state repression on the time to adopting a stay-at-home order

\begin{tabular}{|c|c|c|c|c|}
\hline & \multicolumn{4}{|c|}{ Days from 1st case to policy } \\
\hline & $(1)$ & (2) & (3) & $(4)$ \\
\hline $\begin{array}{l}\mathrm{N} \text { of violent events }(\mathrm{log}) \\
\text { (per one million population) }\end{array}$ & $\begin{array}{c}0.43^{* * *} \\
(0.10)\end{array}$ & $\begin{array}{c}0.39^{* * *} \\
(0.11)\end{array}$ & $\begin{array}{c}0.44^{* * *} \\
(0.11)\end{array}$ & $\begin{array}{c}0.42^{* * *} \\
(0.12)\end{array}$ \\
\hline Democracy score (V-Dem) & & $\begin{array}{l}-0.33 \\
(0.59)\end{array}$ & $\begin{array}{l}0.003 \\
(0.62)\end{array}$ & $\begin{array}{c}0.69 \\
(0.70)\end{array}$ \\
\hline State Capacity & & $\begin{array}{l}-0.21 \\
(0.20)\end{array}$ & $\begin{array}{c}-0.64^{* *} \\
(0.26)\end{array}$ & $\begin{array}{l}-0.43 \\
(0.28)\end{array}$ \\
\hline $\begin{array}{l}\text { Intrastate Armed Conflict } \\
\text { (Historical) }\end{array}$ & & $\begin{array}{l}-0.11 \\
(0.26)\end{array}$ & $\begin{array}{c}0.02 \\
(0.26)\end{array}$ & $\begin{array}{c}0.11 \\
(0.26)\end{array}$ \\
\hline GDP per capita (log) & & & $\begin{array}{l}0.46^{* *} \\
(0.19)\end{array}$ & $\begin{array}{l}0.41^{*} \\
(0.21)\end{array}$ \\
\hline GDP Annual Growth & & & $\begin{array}{c}0.04 \\
(0.04)\end{array}$ & $\begin{array}{c}0.01 \\
(0.04)\end{array}$ \\
\hline Population Density ('000) & & & $\begin{array}{c}0.49 \\
(0.45)\end{array}$ & $\begin{array}{c}0.62 \\
(0.46)\end{array}$ \\
\hline $\begin{array}{l}\text { Population aged } 70 \\
\text { or older (percentage) }\end{array}$ & & & & $\begin{array}{l}-0.10 \\
(0.06)\end{array}$ \\
\hline Diabetes prevalence & & & & $\begin{array}{c}0.04 \\
(0.04)\end{array}$ \\
\hline Cardiovascular death rate & & & & $\begin{array}{l}0.002^{*} \\
(0.001)\end{array}$ \\
\hline Region FE & Yes & Yes & Yes & Yes \\
\hline Observations & 135 & 135 & 135 & 135 \\
\hline
\end{tabular}

${ }^{*} \mathrm{p}<0.1 ;{ }^{* *} \mathrm{p}<0.05 ;{ }^{* * *} \mathrm{p}<0.01$. Standard errors in parenthesis. Region-Fixed Effects include: Africa, Asia, Europe, North America, and South America. 


\section{E.3 Re-evaluating Hypothesis 3 Using All Violence Against Civil- ians}


Table E.3: OLS regressions on the effect of repression on the length of stay-at-home orders

\begin{tabular}{|c|c|c|c|c|}
\hline & \multicolumn{4}{|c|}{ Number of days with policy $(\log )$} \\
\hline & $(1)$ & $(2)$ & $(3)$ & $(4)$ \\
\hline $\begin{array}{l}\mathrm{N} \text { of violent events (log) } \\
\text { (per one million population) }\end{array}$ & $\begin{array}{l}0.50^{* * *} \\
(0.15)\end{array}$ & $\begin{array}{l}0.38^{* *} \\
(0.18)\end{array}$ & $\begin{array}{l}0.43^{* *} \\
(0.17)\end{array}$ & $\begin{array}{l}0.39^{* *} \\
(0.17)\end{array}$ \\
\hline Democracy score (V-Dem) & & $\begin{array}{l}-0.61 \\
(1.19)\end{array}$ & $\begin{array}{l}-0.09 \\
(1.25)\end{array}$ & $\begin{array}{c}1.06 \\
(1.19)\end{array}$ \\
\hline State capacity & & $\begin{array}{l}-0.18 \\
(0.32)\end{array}$ & $\begin{array}{l}-0.63 \\
(0.42)\end{array}$ & $\begin{array}{l}-0.12 \\
(0.40)\end{array}$ \\
\hline $\begin{array}{l}\text { Intrastate Armed Conflict } \\
\text { (Historical) }\end{array}$ & & $\begin{array}{c}0.35 \\
(0.41)\end{array}$ & $\begin{array}{c}0.44 \\
(0.43)\end{array}$ & $\begin{array}{c}0.59 \\
(0.42)\end{array}$ \\
\hline GDP per capita (log) & & & $\begin{array}{l}0.56^{*} \\
(0.31)\end{array}$ & $\begin{array}{c}0.46 \\
(0.37)\end{array}$ \\
\hline GDP Annual Growth & & & $\begin{array}{l}0.003 \\
(0.06)\end{array}$ & $\begin{array}{l}-0.03 \\
(0.06)\end{array}$ \\
\hline Population Density ('000) & & & $\begin{array}{c}0.27 \\
(0.65)\end{array}$ & $\begin{array}{c}0.55 \\
(0.91)\end{array}$ \\
\hline $\begin{array}{l}\text { Population aged } 70 \text { or older } \\
\text { (percentage) }\end{array}$ & & & & $\begin{array}{c}-0.25^{* * *} \\
(0.08)\end{array}$ \\
\hline Diabetes prevalence & & & & $\begin{array}{c}0.07 \\
(0.07)\end{array}$ \\
\hline Cardiovascular death rate & & & & $\begin{array}{l}0.004^{*} \\
(0.002)\end{array}$ \\
\hline Constant & $\begin{array}{c}2.03^{* * *} \\
(0.36)\end{array}$ & $\begin{array}{c}2.01^{* * *} \\
(0.75)\end{array}$ & $\begin{array}{l}-3.19 \\
(3.01)\end{array}$ & $\begin{array}{l}-3.36 \\
(3.46)\end{array}$ \\
\hline Region FE & Yes & Yes & Yes & Yes \\
\hline Observations & 135 & 135 & 135 & 135 \\
\hline
\end{tabular}

${ }^{*} \mathrm{p}<0.1 ;{ }^{* *} \mathrm{p}<0.05 ;{ }^{* * *} \mathrm{p}<0.01$. R6bust standard errors in parenthesis. Region-Fixed Effects include: Africa, Asia, Europe, North America, and South America. 


\section{F Robustness Checks to Using a More Comprehensive Country Sample}

Whereas the models that use the latent human rights scores include nearly all world countries, the list of countries with available data in the ACLED in 2019 excludes significant world regions such as North America (United States and Canada), Western Europe (e.g., France, Germany, United Kingdom), and Oceania (e.g., Australia, New Zealand). The manner in which countries are missing from the data is not random: the excluded countries tend to have governments that, on average, use less violence against their citizens, are more democratic and developed, enjoy from greater state capacity, stronger medical infrastructure and, for these and many other reasons, they could have responded to the pandemic in a different way. Note that this missingness would impact our findings if these countries constitute a subset of world countries that have the least violence against civilians and, at the same time, reacted earlier to the pandemic, were more likely to adopt policies, and imposed policies for longer periods compared to countries in the ACLED sample.

While we do not have the resources to build a fine-grained data on political violence comparable to the ACLED for these out-of-sample countries, we evaluate the impact of their inclusion by assuming that all countries outside of the ACLED have had no record of state violence against citizens in 2019 - this is the most conservative value of state repression in these countries. We use the same data sources as described in the "Research Methods" section to build the rest of the dependent and control variables. Using this new dataset of up to 185 countries, the results reported in the online Appendix F show that the statistical reliability of the main coefficients remain substantively unaltered. Overall, this evidence suggests that the convenience sample provided by ACLED is unlikely to drive the main findings.

Using the same ACLED sample as described in the main text, we assign 0 to all the countries with a missing value in the measure of the number of ACLED events involving 
violence against civilians. We now proceed to evaluate the robustness of our three main hypotheses to the inclusion of these countries in the ACLED Models:

- For a re-evaluation of Hypothesis 1, see Appendix F.1.

- For a re-evaluation of Hypothesis 2, see Appendix F.2.

- For a re-evaluation of Hypothesis 3, see Appendix F.3. 
F.1 Re-evaluating Hypothesis 1 with an expanded country sample 
Table F.1: Logistic regressions on the effect of recent state repression on adopting stay-athome orders (expanded sample)

\begin{tabular}{|c|c|c|c|c|}
\hline & \multicolumn{4}{|c|}{ Adoption of a stay-at-home order } \\
\hline & $(1)$ & $(2)$ & $(3)$ & $(4)$ \\
\hline $\begin{array}{l}\mathrm{N} \text { of violent events }(\log ) \\
\text { (per one million population) }\end{array}$ & $\begin{array}{l}0.71^{* * *} \\
(0.22)\end{array}$ & $\begin{array}{l}0.49^{* *} \\
(0.24)\end{array}$ & $\begin{array}{l}0.57^{* *} \\
(0.26)\end{array}$ & $\begin{array}{c}0.46^{*} \\
(0.27)\end{array}$ \\
\hline Democracy score (V-Dem) & & $\begin{array}{l}-0.54 \\
(0.99)\end{array}$ & $\begin{array}{c}0.25 \\
(1.05)\end{array}$ & $\begin{array}{c}1.74 \\
(1.23)\end{array}$ \\
\hline State Capacity & & $\begin{array}{l}-0.10 \\
(0.29)\end{array}$ & $\begin{array}{l}-0.75^{*} \\
(0.41)\end{array}$ & $\begin{array}{l}-0.34 \\
(0.45)\end{array}$ \\
\hline $\begin{array}{l}\text { Intrastate Armed Conflict } \\
\text { (Historical) }\end{array}$ & & $\begin{array}{l}0.66^{*} \\
(0.40)\end{array}$ & $\begin{array}{l}0.84^{* *} \\
(0.41)\end{array}$ & $\begin{array}{l}1.01^{* *} \\
(0.44)\end{array}$ \\
\hline GDP per capita (log) & & & $\begin{array}{l}0.66^{*} \\
(0.34)\end{array}$ & $\begin{array}{c}0.34 \\
(0.38)\end{array}$ \\
\hline GDP Annual Growth & & & $\begin{array}{l}-0.02 \\
(0.06)\end{array}$ & $\begin{array}{l}-0.05 \\
(0.07)\end{array}$ \\
\hline Population Density ('000) & & & $\begin{array}{c}0.41 \\
(0.44)\end{array}$ & $\begin{array}{c}0.38 \\
(0.42)\end{array}$ \\
\hline $\begin{array}{l}\text { Population aged } 70 \\
\text { or older (percentage) }\end{array}$ & & & & $\begin{array}{l}-0.08 \\
(0.10)\end{array}$ \\
\hline Diabetes prevalence & & & & $\begin{array}{c}0.23^{* * *} \\
(0.08)\end{array}$ \\
\hline Cardiovascular death rate & & & & $\begin{array}{c}0.004 \\
(0.002)\end{array}$ \\
\hline Constant & $\begin{array}{l}-0.11 \\
(0.33)\end{array}$ & $\begin{array}{l}-0.18 \\
(0.66)\end{array}$ & $\begin{array}{r}-6.46^{*} \\
(3.33)\end{array}$ & $\begin{array}{c}-6.14^{*} \\
(3.62)\end{array}$ \\
\hline Region FE & Yes & Yes & Yes & Yes \\
\hline Observations & $\frac{185}{30}$ & 181 & 181 & 179 \\
\hline
\end{tabular}

${ }^{*} \mathrm{p}<0.1 ;{ }^{* *} \mathrm{p}<0.05 ;{ }^{* * *} \mathrm{p}<0.01$. Standard errors in parenthesis. Region-Fixed Effects include: Africa, Asia, Europe, North Amer- 
F.2 Re-evaluating Hypothesis 2 with an expanded country sample 
Table F.2: Cox proportional hazards models of estimating the effect of state repression on the time to adopting a stay-at-home order (expanded sample)

\begin{tabular}{|c|c|c|c|c|}
\hline & \multicolumn{4}{|c|}{ Days from 1st case to policy } \\
\hline & $(1)$ & $(2)$ & $(3)$ & $(4)$ \\
\hline $\begin{array}{l}\mathrm{N} \text { of violent events (log) } \\
\text { (per one million population) }\end{array}$ & $\begin{array}{c}0.49^{* * *} \\
(0.09)\end{array}$ & $\begin{array}{c}0.37^{* * *} \\
(0.11)\end{array}$ & $\begin{array}{c}0.42^{* * *} \\
(0.12)\end{array}$ & $\begin{array}{c}0.38^{* * *} \\
(0.12)\end{array}$ \\
\hline Democracy score (V-Dem) & & $\begin{array}{l}-0.19 \\
(0.54)\end{array}$ & $\begin{array}{c}0.16 \\
(0.58)\end{array}$ & $\begin{array}{c}0.82 \\
(0.65)\end{array}$ \\
\hline State Capacity & & $\begin{array}{l}-0.27 \\
(0.16)\end{array}$ & $\begin{array}{c}-0.63^{* * *} \\
(0.21)\end{array}$ & $\begin{array}{c}-0.47^{* *} \\
(0.23)\end{array}$ \\
\hline $\begin{array}{l}\text { Intrastate Armed Conflict } \\
\text { (Historical) }\end{array}$ & & $\begin{array}{c}0.08 \\
(0.23)\end{array}$ & $\begin{array}{c}0.20 \\
(0.23)\end{array}$ & $\begin{array}{c}0.28 \\
(0.23)\end{array}$ \\
\hline GDP per capita (log) & & & $\begin{array}{l}0.40^{* *} \\
(0.16)\end{array}$ & $\begin{array}{c}0.30 \\
(0.19)\end{array}$ \\
\hline GDP Annual Growth & & & $\begin{array}{c}0.01 \\
(0.03)\end{array}$ & $\begin{array}{c}0.0004 \\
(0.03)\end{array}$ \\
\hline Population Density ('000) & & & $\begin{array}{c}0.16 \\
(0.14)\end{array}$ & $\begin{array}{c}0.16 \\
(0.14)\end{array}$ \\
\hline $\begin{array}{l}\text { Population aged } 70 \\
\text { or older (percentage) }\end{array}$ & & & & $\begin{array}{l}-0.02 \\
(0.05)\end{array}$ \\
\hline Diabetes prevalence & & & & $\begin{array}{l}0.08^{* *} \\
(0.03)\end{array}$ \\
\hline Cardiovascular death rate & & & & $\begin{array}{c}0.001 \\
(0.001)\end{array}$ \\
\hline Region FE & Yes & Yes & Yes & Yes \\
\hline Observations & 185 & 181 & 181 & 179 \\
\hline
\end{tabular}

${ }^{*} \mathrm{p}<0.1 ;{ }^{* *} \mathrm{p}<0.05 ;{ }^{* * *} \mathrm{p}<0.01$. Standard errors in parenthesis. Region-Fixed Effects include: Africa, Asia, Europe, North America, South America, and Oceania. 
F.3 Re-evaluating Hypothesis 3 with an expanded country sample 
Table F.3: OLS regressions on the effect of repression on the length of stay-at-home orders (expanded sample)

\begin{tabular}{|c|c|c|c|c|}
\hline & \multicolumn{4}{|c|}{ Number of days with policy (log) } \\
\hline & (1) & $(2)$ & $(3)$ & (4) \\
\hline $\begin{array}{l}\mathrm{N} \text { of violent events (log) } \\
\text { (per one million population) }\end{array}$ & $\begin{array}{c}0.67^{* * *} \\
(0.18)\end{array}$ & $\begin{array}{l}0.43^{* *} \\
(0.20)\end{array}$ & $\begin{array}{l}0.44^{* *} \\
(0.19)\end{array}$ & $\begin{array}{l}0.39^{* *} \\
(0.18)\end{array}$ \\
\hline Democracy score (V-Dem) & & $\begin{array}{l}-0.61 \\
(1.19)\end{array}$ & $\begin{array}{c}0.02 \\
(1.08)\end{array}$ & $\begin{array}{c}1.07 \\
(1.07)\end{array}$ \\
\hline State capacity & & $\begin{array}{l}-0.20 \\
(0.31)\end{array}$ & $\begin{array}{c}-0.67^{*} \\
(0.36)\end{array}$ & $\begin{array}{l}-0.28 \\
(0.37)\end{array}$ \\
\hline $\begin{array}{l}\text { Intrastate Armed Conflict } \\
\text { (Historical) }\end{array}$ & & $\begin{array}{c}0.65 \\
(0.41)\end{array}$ & $\begin{array}{l}0.75^{* *} \\
(0.37)\end{array}$ & $\begin{array}{l}0.91^{* *} \\
(0.37)\end{array}$ \\
\hline GDP per capita (log) & & & $\begin{array}{c}0.45 \\
(0.29)\end{array}$ & $\begin{array}{c}0.30 \\
(0.32)\end{array}$ \\
\hline GDP Annual Growth & & & $\begin{array}{l}-0.03 \\
(0.05)\end{array}$ & $\begin{array}{l}-0.06 \\
(0.05)\end{array}$ \\
\hline Population Density ('000) & & & $\begin{array}{c}0.32 \\
(0.29)\end{array}$ & $\begin{array}{c}0.31 \\
(0.38)\end{array}$ \\
\hline $\begin{array}{l}\text { Population aged } 70 \text { or older } \\
\text { (percentage) }\end{array}$ & & & & $\begin{array}{r}-0.13^{*} \\
(0.07)\end{array}$ \\
\hline Diabetes prevalence & & & & $\begin{array}{l}0.11^{* *} \\
(0.05)\end{array}$ \\
\hline Cardiovascular death rate & & & & $\begin{array}{c}0.002 \\
(0.002)\end{array}$ \\
\hline Constant & $\begin{array}{c}2.01^{* * *} \\
(0.35)\end{array}$ & $\begin{array}{l}1.91^{* *} \\
(0.74)\end{array}$ & $\begin{array}{l}-2.37 \\
(2.79)\end{array}$ & $\begin{array}{l}-2.23 \\
(3.11)\end{array}$ \\
\hline Region FE & Yes & Yes & Yes & Yes \\
\hline Observations & 185 & 181 & 181 & 179 \\
\hline
\end{tabular}

${ }^{*} \mathrm{p}<0.1 ;{ }^{* *} \mathrm{p}<0.05 ;{ }^{* * *} \mathrm{p}<0.01$. Rgpust standard errors in parenthesis. Region-Fixed Effects include: Africa, Asia, Europe, North America, and South America. 


\section{G Robustness to Adding an Alternative Measure of State Capacity}

Across all models, we control for state capacity to control for variation in the capacity of states to credibly formulate and implement policies such as stay-at-home orders as well as repressive policies.

While there are a number of indicators of state capacity in the literature, we have chosen the Government Effectiveness from the World Bank Indicators (WBI) for two reasons: 1) Conceptual clarity of the government effectiveness indicator as it specifically measures "the quality of public services, the quality of the civil service and the degree of its independence from political pressures, the quality of policy formulation and implementation, and the credibility of the government's commitment to such policies;" and, 2) Extensive coverage $(\mathrm{N}=$ 193 countries), which means a greater coverage than any other state capacity indicator in the literature (the closest in coverage is the Corruption Perceptions Index (CPI) with 180 countries). With this said, Vaccaro (2020) reports a high correlation $(>0.8)$ with all other available indicators of state capacity. For a review on state capacity indicators, see Vaccaro (2020).

Another indicator from the WBI labeled as 'The Rule of Law' could also capture this concept. The WBI defines it as a measure that "Reflects perceptions of the extent to which agents have confidence in and abide by the rules of society, and in particular the quality of contract enforcement, property rights, the police, and the courts, as well as the likelihood of crime and violence." The correlation between the two indicators: 'the Government Effectiveness' and the 'Rule of Law' is 0.93. Despite the high correlation, we ensure the robustness of our findings to alternative conceptions of state capacity by reestimating our models with this alternative control in this Online Appendix:

- For a re-evaluation of Hypothesis 1, see Appendix G.1.

- For a re-evaluation of Hypothesis 2, see Appendix G.2. 
- For a re-evaluation of Hypothesis 3, see Appendix G.3. 


\section{G.1 Re-evaluating Hypothesis 1 with an alternative indicator of state capacity}

Table G.1: Logistic regressions on the effect of recent state repression on adopting stay-athome orders (alternative indicator of state capacity)

\begin{tabular}{|c|c|c|c|c|c|c|c|c|}
\hline & \multicolumn{8}{|c|}{ Adoption of a stay-at-home order } \\
\hline & $(1)$ & $(2)$ & $(3)$ & $(4)$ & (5) & $(6)$ & $(7)$ & $(8)$ \\
\hline $\begin{array}{l}\mathrm{N} \text { of violent events }(\mathrm{log}) \\
\text { (per one million population) }\end{array}$ & $\begin{array}{r}0.66^{* * *} \\
(0.24)\end{array}$ & $\begin{array}{l}0.64^{* *} \\
(0.27)\end{array}$ & $\begin{array}{l}0.72^{* *} \\
(0.28)\end{array}$ & $\begin{array}{l}0.67^{* *} \\
(0.31)\end{array}$ & & & & \\
\hline Human Rights Protection Score & & & & & $\begin{array}{c}-0.55^{* * *} \\
(0.14)\end{array}$ & $\begin{array}{c}-0.64^{* * *} \\
(0.21)\end{array}$ & $\begin{array}{l}-0.68^{* * *} \\
(0.21)\end{array}$ & $\begin{array}{c}-0.76^{* * *} \\
(0.24)\end{array}$ \\
\hline Democracy score (V-Dem) & & $\begin{array}{l}-1.10 \\
(1.19)\end{array}$ & $\begin{array}{l}-0.45 \\
(1.26)\end{array}$ & $\begin{array}{c}0.95 \\
(1.57)\end{array}$ & & $\begin{array}{c}0.38 \\
(1.12)\end{array}$ & $\begin{array}{l}1.27 \\
(1.21)\end{array}$ & $\begin{array}{l}3.09^{* *} \\
(1.42)\end{array}$ \\
\hline Rule of Law & & $\begin{array}{c}0.28 \\
(0.42)\end{array}$ & $\begin{array}{l}-0.27 \\
(0.53)\end{array}$ & $\begin{array}{c}0.41 \\
(0.62)\end{array}$ & & $\begin{array}{c}0.18 \\
(0.32)\end{array}$ & $\begin{array}{l}-0.29 \\
(0.41)\end{array}$ & $\begin{array}{c}0.31 \\
(0.47)\end{array}$ \\
\hline $\begin{array}{l}\text { Intrastate Armed Conflict } \\
\text { (Historical) }\end{array}$ & & $\begin{array}{c}0.54 \\
(0.46)\end{array}$ & $\begin{array}{c}0.64 \\
(0.47)\end{array}$ & $\begin{array}{l}0.94^{*} \\
(0.52)\end{array}$ & & $\begin{array}{c}0.44 \\
(0.42)\end{array}$ & $\begin{array}{c}0.54 \\
(0.44)\end{array}$ & $\begin{array}{c}0.74 \\
(0.47)\end{array}$ \\
\hline GDP per capita $(\log )$ & & & $\begin{array}{l}0.59^{*} \\
(0.35)\end{array}$ & $\begin{array}{c}0.64 \\
(0.41)\end{array}$ & & & $\begin{array}{c}0.42 \\
(0.30)\end{array}$ & $\begin{array}{c}0.23 \\
(0.33)\end{array}$ \\
\hline GDP Annual Growth & & & $\begin{array}{c}0.01 \\
(0.07)\end{array}$ & $\begin{array}{c}-0.003 \\
(0.08)\end{array}$ & & & $\begin{array}{l}-0.06 \\
(0.06)\end{array}$ & $\begin{array}{l}-0.08 \\
(0.07)\end{array}$ \\
\hline Population Density ('000) & & & $\begin{array}{c}0.81 \\
(1.12)\end{array}$ & $\begin{array}{c}1.87 \\
(1.69)\end{array}$ & & & $\begin{array}{c}0.34 \\
(0.41)\end{array}$ & $\begin{array}{c}0.32 \\
(0.39)\end{array}$ \\
\hline $\begin{array}{l}\text { Population aged } 70 \\
\text { or older (percentage) }\end{array}$ & & & & $\begin{array}{c}-0.33^{* *} \\
(0.14)\end{array}$ & & & & $\begin{array}{l}-0.16 \\
(0.10)\end{array}$ \\
\hline Diabetes prevalence & & & & $\begin{array}{l}0.18^{*} \\
(0.11)\end{array}$ & & & & $\begin{array}{c}0.26^{* * *} \\
(0.09)\end{array}$ \\
\hline Cardiovascular death rate & & & & $\begin{array}{c}0.01^{* *} \\
(0.003)\end{array}$ & & & & $\begin{array}{c}0.01^{* *} \\
(0.002)\end{array}$ \\
\hline Constant & $\begin{array}{l}-0.17 \\
(0.36)\end{array}$ & $\begin{array}{c}0.15 \\
(0.77)\end{array}$ & $\begin{array}{l}-5.46 \\
(3.45)\end{array}$ & $\begin{array}{c}-8.66^{* *} \\
(3.98)\end{array}$ & $\begin{array}{c}0.42 \\
(0.30)\end{array}$ & $\begin{array}{c}0.12 \\
(0.70)\end{array}$ & $\begin{array}{l}-3.88 \\
(2.86)\end{array}$ & $\begin{array}{l}-5.20 \\
(3.19)\end{array}$ \\
\hline Region FE & Yes & Yes & Yes & Yes & Yes & Yes & Yes & Yes \\
\hline Observations & 135 & 135 & 135 & 135 & 182 & 180 & 180 & 178 \\
\hline
\end{tabular}

${ }^{*} \mathrm{p}<0.1 ;{ }^{* *} \mathrm{p}<0.05 ;{ }^{* * *} \mathrm{p}<0.01$. Standard errors in parenthesis. Region-Fixed Effects include:

Africa, Asia, Europe, North America, South America, and Oceania. 


\section{G.2 Re-evaluating Hypothesis 2 with an alternative indicator of state capacity}

Table G.2: Cox proportional hazards models of estimating the effect of state repression on the time to adopting a stay-at-home order (alternative indicator of state capacity)

\begin{tabular}{|c|c|c|c|c|c|c|c|c|}
\hline & \multicolumn{8}{|c|}{ Number of days since the first COVID-19 case to policy } \\
\hline & $(1)$ & $(2)$ & $(3)$ & $(4)$ & $(5)$ & (6) & (7) & $(8)$ \\
\hline $\begin{array}{l}\mathrm{N} \text { of violent events (log) } \\
\text { (per one million population) }\end{array}$ & $\begin{array}{c}0.48^{* * *} \\
(0.10)\end{array}$ & $\begin{array}{c}0.46^{* * *} \\
(0.12)\end{array}$ & $\begin{array}{c}0.48^{* * *} \\
(0.12)\end{array}$ & $\begin{array}{c}0.45^{* * *} \\
(0.13)\end{array}$ & & & & \\
\hline Human Rights Protection Score & & & & & $\begin{array}{c}-0.32^{* * *} \\
(0.07)\end{array}$ & $\begin{array}{c}-0.32^{* * *} \\
(0.11)\end{array}$ & $\begin{array}{c}-0.32^{* * *} \\
(0.11)\end{array}$ & $\begin{array}{c}-0.29^{* * *} \\
(0.11)\end{array}$ \\
\hline Democracy score (V-Dem) & & $\begin{array}{l}-0.53 \\
(0.62)\end{array}$ & $\begin{array}{l}-0.21 \\
(0.66)\end{array}$ & $\begin{array}{c}0.54 \\
(0.76)\end{array}$ & & $\begin{array}{c}0.39 \\
(0.60)\end{array}$ & $\begin{array}{c}0.76 \\
(0.64)\end{array}$ & $\begin{array}{l}1.46^{* *} \\
(0.70)\end{array}$ \\
\hline Rule of Law & & $\begin{array}{l}-0.03 \\
(0.22)\end{array}$ & $\begin{array}{l}-0.32 \\
(0.28)\end{array}$ & $\begin{array}{l}-0.11 \\
(0.32)\end{array}$ & & $\begin{array}{l}-0.15 \\
(0.17)\end{array}$ & $\begin{array}{l}-0.32 \\
(0.22)\end{array}$ & $\begin{array}{l}-0.21 \\
(0.25)\end{array}$ \\
\hline $\begin{array}{l}\text { Intrastate Armed Conflict } \\
\text { (Historical) }\end{array}$ & & $\begin{array}{l}-0.04 \\
(0.26)\end{array}$ & $\begin{array}{c}0.03 \\
(0.26)\end{array}$ & $\begin{array}{c}0.13 \\
(0.26)\end{array}$ & & $\begin{array}{c}0.03 \\
(0.24)\end{array}$ & $\begin{array}{c}0.08 \\
(0.24)\end{array}$ & $\begin{array}{c}0.14 \\
(0.25)\end{array}$ \\
\hline GDP per capita $(\log )$ & & & $\begin{array}{c}0.30^{*} \\
(0.18)\end{array}$ & $\begin{array}{c}0.26 \\
(0.20)\end{array}$ & & & $\begin{array}{c}0.16 \\
(0.16)\end{array}$ & $\begin{array}{c}0.05 \\
(0.18)\end{array}$ \\
\hline GDP Annual Growth & & & $\begin{array}{c}0.02 \\
(0.04)\end{array}$ & $\begin{array}{l}-0.01 \\
(0.04)\end{array}$ & & & $\begin{array}{l}-0.03 \\
(0.03)\end{array}$ & $\begin{array}{l}-0.03 \\
(0.03)\end{array}$ \\
\hline Population Density ('000) & & & $\begin{array}{c}0.36 \\
(0.50)\end{array}$ & $\begin{array}{c}0.53 \\
(0.48)\end{array}$ & & & $\begin{array}{c}0.15 \\
(0.13)\end{array}$ & $\begin{array}{c}0.14 \\
(0.14)\end{array}$ \\
\hline $\begin{array}{l}\text { Population aged } 70 \\
\text { or older (percentage) }\end{array}$ & & & & $\begin{array}{c}-0.12^{*} \\
(0.06)\end{array}$ & & & & $\begin{array}{l}-0.04 \\
(0.05)\end{array}$ \\
\hline Diabetes prevalence & & & & $\begin{array}{c}0.04 \\
(0.04)\end{array}$ & & & & $\begin{array}{c}0.10^{* * *} \\
(0.03)\end{array}$ \\
\hline Cardiovascular death rate & & & & $\begin{array}{l}0.002^{* *} \\
(0.001)\end{array}$ & & & & $\begin{array}{c}0.001 \\
(0.001)\end{array}$ \\
\hline Regi & Yes & Yes & Yes & Yes & Yes & Yes & Yes & Yes \\
\hline Observations & 135 & 135 & 135 & 135 & 182 & 180 & 180 & 178 \\
\hline
\end{tabular}

${ }^{*} \mathrm{p}<0.1 ;{ }^{* *} \mathrm{p}<0.05 ;{ }^{* * *} \mathrm{p}<0.01$. Standard errors in parenthesis. Region-Fixed Effects include:

Africa, Asia, Europe, North America, South America, and Oceania. 


\section{G.3 Re-evaluating Hypothesis 3 with an alternative indicator of state capacity}

Table G.3: OLS regressions on the effect of repression on the length of stay-at-home orders (alternative indicator of state capacity)

\begin{tabular}{|c|c|c|c|c|c|c|c|c|}
\hline & \multicolumn{8}{|c|}{ Number of days with stay-at-home order $(\log )$} \\
\hline & (1) & $(2)$ & (3) & $(4)$ & (5) & (6) & (7) & (8) \\
\hline $\begin{array}{l}\mathrm{N} \text { of violent events }(\mathrm{log}) \\
\text { (per one million population) }\end{array}$ & $\begin{array}{r}0.59^{* * *} \\
(0.18)\end{array}$ & $\begin{array}{l}0.53^{* *} \\
(0.21)\end{array}$ & $\begin{array}{c}0.55^{* * *} \\
(0.21)\end{array}$ & $\begin{array}{l}0.50^{* *} \\
(0.20)\end{array}$ & & & & \\
\hline Human Rights Protection Score & & & & & $\begin{array}{l}-0.41^{* * *} \\
(0.09)\end{array}$ & $\begin{array}{l}-0.53^{* * *} \\
(0.15)\end{array}$ & $\begin{array}{c}-0.58^{* * *} \\
(0.15)\end{array}$ & $\begin{array}{l}-0.52^{* * *} \\
(0.15)\end{array}$ \\
\hline Democracy score (V-Dem) & & $\begin{array}{l}-0.94 \\
(1.23)\end{array}$ & $\begin{array}{l}-0.50 \\
(1.30)\end{array}$ & $\begin{array}{c}0.72 \\
(1.26)\end{array}$ & & $\begin{array}{c}1.11 \\
(0.88)\end{array}$ & $\begin{array}{l}1.78^{* *} \\
(0.90)\end{array}$ & $\begin{array}{l}2.63^{* * *} \\
(1.00)\end{array}$ \\
\hline Rule of Law & & $\begin{array}{c}0.06 \\
(0.37)\end{array}$ & $\begin{array}{l}-0.24 \\
(0.46)\end{array}$ & $\begin{array}{c}0.15 \\
(0.44)\end{array}$ & & & & \\
\hline $\begin{array}{l}\text { Intrastate Armed Conflict } \\
\text { (Historical) }\end{array}$ & & $\begin{array}{c}0.41 \\
(0.42)\end{array}$ & $\begin{array}{c}0.46 \\
(0.44)\end{array}$ & $\begin{array}{c}0.64 \\
(0.43)\end{array}$ & & $\begin{array}{c}0.38 \\
(0.38)\end{array}$ & $\begin{array}{c}0.48 \\
(0.37)\end{array}$ & $\begin{array}{c}0.59 \\
(0.37)\end{array}$ \\
\hline GDP per capita $(\log )$ & & & $\begin{array}{c}0.36 \\
(0.29)\end{array}$ & $\begin{array}{c}0.39 \\
(0.33)\end{array}$ & & & $\begin{array}{l}0.62^{* * *} \\
(0.24)\end{array}$ & $\begin{array}{c}0.42 \\
(0.28)\end{array}$ \\
\hline GDP Annual Growth & & & $\begin{array}{l}-0.02 \\
(0.06)\end{array}$ & $\begin{array}{l}-0.04 \\
(0.06)\end{array}$ & & & $\begin{array}{l}-0.05 \\
(0.05)\end{array}$ & $\begin{array}{l}-0.08 \\
(0.05)\end{array}$ \\
\hline Population Density ('000) & & & $\begin{array}{c}0.28 \\
(0.70)\end{array}$ & $\begin{array}{c}0.53 \\
(0.94)\end{array}$ & & & $\begin{array}{c}0.28 \\
(0.44)\end{array}$ & $\begin{array}{c}0.25 \\
(0.55)\end{array}$ \\
\hline $\begin{array}{l}\text { Population aged } 70 \\
\text { or older (percentage) }\end{array}$ & & & & $\begin{array}{l}-0.26^{* * *} \\
(0.08)\end{array}$ & & & & $\begin{array}{l}-0.05 \\
(0.05)\end{array}$ \\
\hline Diabetes prevalence & & & & $\begin{array}{c}0.06 \\
(0.07)\end{array}$ & & & & $\begin{array}{l}0.11^{* *} \\
(0.05)\end{array}$ \\
\hline Cardiovascular death rate & & & & $\begin{array}{l}0.004^{* *} \\
(0.002)\end{array}$ & & & & $\begin{array}{l}0.003^{*} \\
(0.002)\end{array}$ \\
\hline Constant & $\begin{array}{c}2.03^{* * *} \\
(0.35)\end{array}$ & $\begin{array}{c}2.24^{* * *} \\
(0.74)\end{array}$ & $\begin{array}{l}-1.09 \\
(2.82)\end{array}$ & $\begin{array}{l}-2.48 \\
(3.10)\end{array}$ & $\begin{array}{c}3.20^{* * *} \\
(0.17)\end{array}$ & $\begin{array}{c}2.48^{* * *} \\
(0.53)\end{array}$ & $\begin{array}{l}-3.56 \\
(2.42)\end{array}$ & $\begin{array}{l}-3.53 \\
(2.75)\end{array}$ \\
\hline Region FE & Yes & Yes & Yes & Yes & Yes & Yes & Yes & Yes \\
\hline Observations & 135 & 135 & 135 & 135 & 182 & 180 & 180 & 178 \\
\hline
\end{tabular}

${ }^{*} \mathrm{p}<0.1 ;{ }^{* *} \mathrm{p}<0.05 ;{ }^{* * *} \mathrm{p}<0.01$. Standard errors in parenthesis. Region-Fixed Effects include:

Africa, Asia, Europe, North America, South America, and Oceania. 


\section{H Robustness to Police and Military Personnel}

An argument could be made that abusive states could have greater resources, could be more capable of and more ready for using force within its own borders to restrict people's freedom of movement. While we cannot directly measure a country's capacity to enforce a stay-athome order, we could capture capability of restricting internal freedoms of movements by measuring (a) the number of military personnel in active, regular military units of the land, naval, and air components; and, (b) the best estimate of the number of police officers per 100 inhabitants. As imperfect as these measures might be, we expect them to be positively correlated with a country's capacity to enforce a stay-at-home order. Our results indicate that adding these "capacity to enforce" controls do not affect our main explanatory variables. This suggests that the drivers of our association is more likely to be governments' willingness rather than governments' capacity to enforce restrictions. 


\section{H.1 Re-evaluating Hypothesis 1 after controlling for army and police personnel}

Table H.1: Logistic regressions on the effect of recent state repression on adopting stay-athome orders

\begin{tabular}{|c|c|c|c|c|}
\hline & \multicolumn{4}{|c|}{ Adoption of a stay-at-home order } \\
\hline & $(1)$ & $(2)$ & $(3)$ & $(4)$ \\
\hline $\begin{array}{l}\mathrm{N} \text { of violent events }(\log ) \\
\text { (per one million population) }\end{array}$ & $\begin{array}{l}0.62^{*} \\
(0.33)\end{array}$ & $\begin{array}{l}1.01^{*} \\
(0.58)\end{array}$ & & \\
\hline Human Rights Protection Score & & & $\begin{array}{c}-0.91^{* * *} \\
(0.26)\end{array}$ & $\begin{array}{c}-0.75^{* * *} \\
(0.28)\end{array}$ \\
\hline Armed combat personal (\%) & $\begin{array}{c}0.20 \\
(0.62)\end{array}$ & & $\begin{array}{c}0.17 \\
(0.51)\end{array}$ & \\
\hline $\begin{array}{l}\text { Number of police officers } \\
\text { (per } 100,000 \text { people) }\end{array}$ & & $\begin{array}{c}0.001 \\
(0.002)\end{array}$ & & $\begin{array}{l}-0.001 \\
(0.002)\end{array}$ \\
\hline Democracy score (V-Dem) & $\begin{array}{c}1.18 \\
(1.46)\end{array}$ & $\begin{array}{l}1.16 \\
(2.55)\end{array}$ & $\begin{array}{l}3.31^{* *} \\
(1.45)\end{array}$ & $\begin{array}{l}4.12^{*} \\
(2.12)\end{array}$ \\
\hline State Capacity & $\begin{array}{c}0.07 \\
(0.62)\end{array}$ & $\begin{array}{l}-0.60 \\
(1.29)\end{array}$ & $\begin{array}{l}-0.32 \\
(0.51)\end{array}$ & $\begin{array}{l}-1.57^{*} \\
(0.90)\end{array}$ \\
\hline $\begin{array}{l}\text { Intrastate Armed Conflict } \\
\text { (Historical) }\end{array}$ & $\begin{array}{l}0.88^{*} \\
(0.52)\end{array}$ & $\begin{array}{l}1.45 \\
(0.97)\end{array}$ & $\begin{array}{c}0.66 \\
(0.49)\end{array}$ & $\begin{array}{c}0.94 \\
(0.74)\end{array}$ \\
\hline GDP per capita (log) & $\begin{array}{c}0.69 \\
(0.48)\end{array}$ & $\begin{array}{c}1.27 \\
(0.90)\end{array}$ & $\begin{array}{c}0.66 \\
(0.42)\end{array}$ & $\begin{array}{c}0.73 \\
(0.70)\end{array}$ \\
\hline GDP Annual Growth & $\begin{array}{c}0.02 \\
(0.08)\end{array}$ & $\begin{array}{c}-0.004 \\
(0.13)\end{array}$ & $\begin{array}{l}-0.03 \\
(0.07)\end{array}$ & $\begin{array}{l}-0.06 \\
(0.11)\end{array}$ \\
\hline Population density & $\begin{array}{c}0.003 \\
(0.002)\end{array}$ & $\begin{array}{c}0.01 \\
(0.003)\end{array}$ & $\begin{array}{c}0.001 \\
(0.001)\end{array}$ & $\begin{array}{c}0.001 \\
(0.0005)\end{array}$ \\
\hline $\begin{array}{l}\text { Population aged } 70 \\
\text { (or older) }\end{array}$ & $\begin{array}{c}-0.28^{*} \\
(0.14)\end{array}$ & $\begin{array}{c}-0.73^{* * *} \\
(0.27)\end{array}$ & $\begin{array}{l}-0.08 \\
(0.11)\end{array}$ & $\begin{array}{l}-0.22 \\
(0.14)\end{array}$ \\
\hline Diabetes prevalence & $\begin{array}{c}0.20^{*} \\
(0.11)\end{array}$ & $\begin{array}{l}0.45^{* *} \\
(0.22)\end{array}$ & $\begin{array}{l}0.22^{* *} \\
(0.09)\end{array}$ & $\begin{array}{l}0.37^{* *} \\
(0.15)\end{array}$ \\
\hline Cardiovascular death rate & $\begin{array}{c}0.01^{* *} \\
(0.003)\end{array}$ & $\begin{array}{c}0.01 \\
(0.01)\end{array}$ & $\begin{array}{l}0.004^{*} \\
(0.002)\end{array}$ & $\begin{array}{l}-0.003 \\
(0.004)\end{array}$ \\
\hline Region FE & Yes & Yes & Yes & Yes \\
\hline Observations & 126 & 75 & 164 & 113 \\
\hline
\end{tabular}

${ }^{*} \mathrm{p}<0.1 ;{ }^{* *} \mathrm{p}<0.05 ;{ }^{* * *} \mathrm{p}<0.01$. Standard errors in parenthesis. Region-Fixed Effects include: Africa, Asia, Europe, North America, South America, and Oceania. Constant omitted. 


\section{H.2 Re-evaluating Hypothesis 2 after controlling for army and police personnel}

Table H.2: Cox proportional hazards models of estimating the effect of state repression on the time to adopting a stay-at-home order

\begin{tabular}{|c|c|c|c|c|}
\hline & \multicolumn{4}{|c|}{$\begin{array}{l}\text { Number of days since the first } \\
\text { COVID-19 case until stay-at-home order }\end{array}$} \\
\hline & $(1)$ & $(2)$ & $(3)$ & $(4)$ \\
\hline $\begin{array}{l}\mathrm{N} \text { of violent events }(\mathrm{log}) \\
\text { (per one million population) }\end{array}$ & $\begin{array}{c}0.40^{* * *} \\
(0.13)\end{array}$ & $\begin{array}{c}0.49^{* * *} \\
(0.15)\end{array}$ & & \\
\hline Human Rights Protection Score & & & $\begin{array}{c}-0.35^{* * *} \\
(0.11)\end{array}$ & $\begin{array}{c}-0.30^{* *} \\
(0.13)\end{array}$ \\
\hline Armed combat personal (\%) & $\begin{array}{c}0.02 \\
(0.28)\end{array}$ & & $\begin{array}{l}-0.03 \\
(0.27)\end{array}$ & \\
\hline $\begin{array}{l}\text { Number of police officers } \\
\text { (per } 100,000 \text { people) }\end{array}$ & & $\begin{array}{c}0.001 \\
(0.001)\end{array}$ & & $\begin{array}{l}0.0001 \\
(0.001)\end{array}$ \\
\hline Democracy score (V-Dem) & $\begin{array}{c}0.64 \\
(0.71)\end{array}$ & $\begin{array}{c}0.58 \\
(1.31)\end{array}$ & $\begin{array}{l}1.45^{* *} \\
(0.71)\end{array}$ & $\begin{array}{c}1.70 \\
(1.10)\end{array}$ \\
\hline State Capacity & $\begin{array}{l}-0.37 \\
(0.30)\end{array}$ & $\begin{array}{l}0.05 \\
(0.48)\end{array}$ & $\begin{array}{c}-0.49^{* *} \\
(0.24)\end{array}$ & $\begin{array}{l}-0.49 \\
(0.37)\end{array}$ \\
\hline $\begin{array}{l}\text { Intrastate Armed Conflict } \\
\text { (Historical) }\end{array}$ & $\begin{array}{c}0.17 \\
(0.26)\end{array}$ & $\begin{array}{c}0.19 \\
(0.38)\end{array}$ & $\begin{array}{c}0.10 \\
(0.25)\end{array}$ & $\begin{array}{c}0.21 \\
(0.34)\end{array}$ \\
\hline GDP per capita (log) & $\begin{array}{c}0.34 \\
(0.22)\end{array}$ & $\begin{array}{c}0.20 \\
(0.34)\end{array}$ & $\begin{array}{c}0.25 \\
(0.19)\end{array}$ & $\begin{array}{c}0.08 \\
(0.30)\end{array}$ \\
\hline GDP annual growth & $\begin{array}{c}0.01 \\
(0.04)\end{array}$ & $\begin{array}{l}-0.04 \\
(0.06)\end{array}$ & $\begin{array}{l}-0.01 \\
(0.03)\end{array}$ & $\begin{array}{c}0.01 \\
(0.05)\end{array}$ \\
\hline Population density & $\begin{array}{c}0.001 \\
(0.0005)\end{array}$ & $\begin{array}{c}0.002^{* *} \\
(0.001)\end{array}$ & $\begin{array}{c}0.0002 \\
(0.0002)\end{array}$ & $\begin{array}{c}0.0002 \\
(0.0001)\end{array}$ \\
\hline $\begin{array}{l}\text { Population aged } 70 \\
\text { (or older) }\end{array}$ & $\begin{array}{l}-0.09 \\
(0.07)\end{array}$ & $\begin{array}{c}-0.23^{* *} \\
(0.10)\end{array}$ & $\begin{array}{c}-0.003 \\
(0.06)\end{array}$ & $\begin{array}{l}-0.01 \\
(0.07)\end{array}$ \\
\hline Diabetes prevalence & $\begin{array}{c}0.04 \\
(0.04)\end{array}$ & $\begin{array}{l}0.10 \\
(0.07)\end{array}$ & $\begin{array}{l}0.08^{* *} \\
(0.03)\end{array}$ & $\begin{array}{c}0.15^{* * *} \\
(0.05)\end{array}$ \\
\hline Cardiovascular death rate & $\begin{array}{l}0.002^{*} \\
(0.001)\end{array}$ & $\begin{array}{c}0.01^{* *} \\
(0.003)\end{array}$ & $\begin{array}{c}0.001 \\
(0.001)\end{array}$ & $\begin{array}{c}-0.0003 \\
(0.002)\end{array}$ \\
\hline Region FE & Yes & Yes & Yes & Yes \\
\hline Observations & 126 & 75 & 164 & 113 \\
\hline
\end{tabular}

${ }^{*} \mathrm{p}<0.1 ;{ }^{* *} \mathrm{p}<0.05 ;{ }^{* * *} \mathrm{p}<0.01$. Standard errors in parenthesis. Region-Fixed Effects include: Africa, Asia, Europe, North America, South America, and Oceania. 


\section{H.3 Re-evaluating Hypothesis 3 after controlling for army and police personnel}

Table H.3: OLS regressions on the effect of repression on the length of stay-at-home orders

\begin{tabular}{|c|c|c|c|c|}
\hline & \multirow{2}{*}{\multicolumn{4}{|c|}{$\begin{array}{c}\text { Number of days with } \\
\text { stay-at-home order in place }(\log )\end{array}$}} \\
\hline & & & & \\
\hline & (1) & (2) & $(3)$ & (4) \\
\hline $\begin{array}{l}\mathrm{N} \text { of violent events (log) } \\
\text { (per one million population) }\end{array}$ & $\begin{array}{l}0.41^{*} \\
(0.23)\end{array}$ & $\begin{array}{l}0.39^{*} \\
(0.22)\end{array}$ & & \\
\hline Human rights protection score & & & $\begin{array}{c}-0.64^{* * *} \\
(0.16)\end{array}$ & $\begin{array}{c}-0.42^{* *} \\
(0.18)\end{array}$ \\
\hline Armed combat personal (\%) & $\begin{array}{l}-0.17 \\
(0.52)\end{array}$ & & $\begin{array}{l}-0.10 \\
(0.41)\end{array}$ & \\
\hline $\begin{array}{l}\text { Number of police officers } \\
\text { (per } 100,000 \text { people) }\end{array}$ & & $\begin{array}{c}-0.0003 \\
(0.001)\end{array}$ & & $\begin{array}{l}-0.001 \\
(0.001)\end{array}$ \\
\hline Democracy score (V-Dem) & $\begin{array}{c}0.93 \\
(1.26)\end{array}$ & $\begin{array}{c}1.02 \\
(1.90)\end{array}$ & $\begin{array}{l}2.73^{* *} \\
(1.07)\end{array}$ & $\begin{array}{l}2.69^{*} \\
(1.42)\end{array}$ \\
\hline State capacity & $\begin{array}{l}-0.11 \\
(0.46)\end{array}$ & $\begin{array}{l}-0.38 \\
(0.70)\end{array}$ & $\begin{array}{l}-0.43 \\
(0.35)\end{array}$ & $\begin{array}{c}-0.82^{*} \\
(0.48)\end{array}$ \\
\hline $\begin{array}{l}\text { Intrastate armed conflict } \\
\text { (Historical) }\end{array}$ & $\begin{array}{c}0.62 \\
(0.45)\end{array}$ & $\begin{array}{c}0.75 \\
(0.63)\end{array}$ & $\begin{array}{c}0.47 \\
(0.39)\end{array}$ & $\begin{array}{c}0.77 \\
(0.49)\end{array}$ \\
\hline GDP per capita (log) & $\begin{array}{c}0.45 \\
(0.44)\end{array}$ & $\begin{array}{c}0.77 \\
(0.62)\end{array}$ & $\begin{array}{l}0.61^{*} \\
(0.32)\end{array}$ & $\begin{array}{c}0.64 \\
(0.46)\end{array}$ \\
\hline GDP annual growth & $\begin{array}{l}-0.03 \\
(0.07)\end{array}$ & $\begin{array}{l}-0.06 \\
(0.09)\end{array}$ & $\begin{array}{l}-0.05 \\
(0.06)\end{array}$ & $\begin{array}{l}-0.07 \\
(0.07)\end{array}$ \\
\hline Population density & $\begin{array}{c}0.001 \\
(0.001)\end{array}$ & $\begin{array}{c}0.002 \\
(0.001)\end{array}$ & $\begin{array}{c}0.0003 \\
(0.0004)\end{array}$ & $\begin{array}{c}0.0004 \\
(0.0005)\end{array}$ \\
\hline $\begin{array}{l}\text { Population aged } 70 \\
\text { (or older) }\end{array}$ & $\begin{array}{c}-0.23^{* * *} \\
(0.08)\end{array}$ & $\begin{array}{c}-0.33^{*} \\
(0.17)\end{array}$ & $\begin{array}{l}-0.04 \\
(0.05)\end{array}$ & $\begin{array}{l}-0.06 \\
(0.06)\end{array}$ \\
\hline Diabetes prevalence & $\begin{array}{c}0.07 \\
(0.07)\end{array}$ & $\begin{array}{c}0.16 \\
(0.11)\end{array}$ & $\begin{array}{l}0.10^{* *} \\
(0.05)\end{array}$ & $\begin{array}{l}0.12^{* *} \\
(0.06)\end{array}$ \\
\hline Cardiovascular death rate & $\begin{array}{l}0.003^{*} \\
(0.002)\end{array}$ & $\begin{array}{c}0.01 \\
(0.003)\end{array}$ & $\begin{array}{c}0.003 \\
(0.002)\end{array}$ & $\begin{array}{c}0.001 \\
(0.002)\end{array}$ \\
\hline Region FE & Yes & Yes & Yes & Yes \\
\hline Observations & 126 & 75 & 164 & 113 \\
\hline
\end{tabular}

${ }^{*} \mathrm{p}<0.1 ;{ }^{* *} \mathrm{p}<0.05 ;{ }^{* * *} \mathrm{p}<0.01$. Standard errors in parenthesis. Region-Fixed Effects include: Africa, Asia, Europe, North America, South America, and Oceania. Constant omitted. 


\section{Robustness to Trust in the Government}

Some readers could believe that governments who have recently engaged in violence against civilians or who score worse on the protection of human rights scores are less likely to be trusted in their pandemic recommendations, necessitating lockdown as an attempt to implement self-protective policy. We empirically evaluate this argument in this Online Appendix.

First, we build a measure that captures the percentage of respondents who reported trusting the government "a great deal" or "quite a lot" obtained from waves 5 and 6 of the WVS (WVS 2018) and the 2018 wave of the Latin Barometer. Computed based on item $E 069_{1} 1$, which asks respondents to self-rate their degree of confidence in the central government: $1=$ a great deal; $2=$ quite a lot; $3=$ not very much; $4=$ none at all. This measure is standardized with a mean of 0 and a sd of 1 . This measure includes only countries sampled since 2009. Of the 135 countries in our ACLED sample, we have been able to find a measure of trust in government from these survey sources for 56 countries. Of the 182 countries in the entire sample, we have been able to find a measure of trust in government from these survey sources for 69 countries. Due to the massive missingness, we have decided not to add this variable in our main models. However, we have developed a strategy to evaluate whether this would constitute a significant confounder in our models.

Figure I.1 shows that trust in government is negatively correlated with the number of violent events against civilians, although not with country's human rights scores among the countries in this subsample of 56 and 69 countries, respectively. The existence of this correlation leads us to believe that trust in government could constitute a potential confounder.

To evaluate the impact of this confounder, we perform multiple imputation to impute values in the trust in government for those countries with missing data. 5 complete datasets are generated. Then, we re-estimate our models, using both number of events and human rights scores as dependent variables, adding the imputed values of the trust in government as a control in the models. The online appendix reports 5 different models (one model 
Figure I.1: Trust in government, state repression, and human rights score

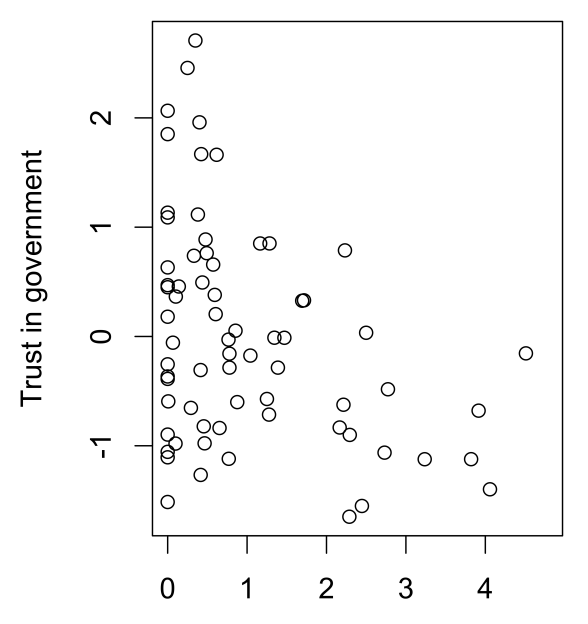

Number of violent events per capita (log)

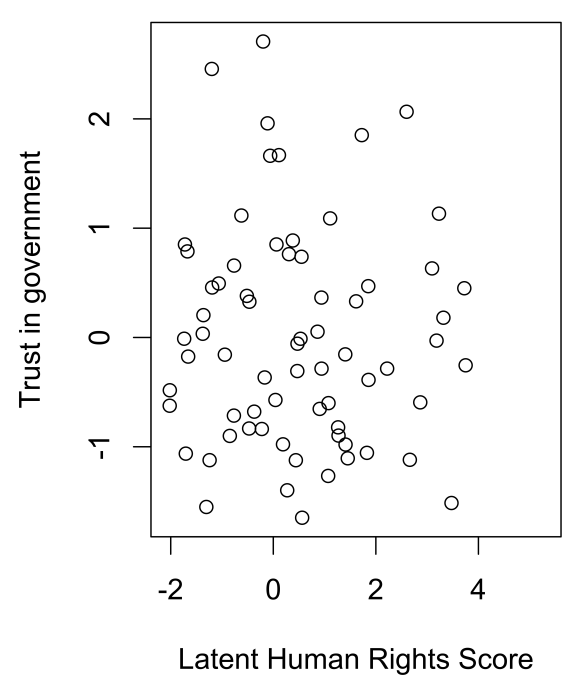

for each imputed trust in government variable). The results from this exercise reveals that our main predictor, either number of violent events per million population or human rights scores, significantly predicts adoption, timing, and length of stay-at-home orders even after controlling for trust in the government. Therefore, we conclude that it is unlikely that trust in the government would be a relevant confounder for our main estimates.

- For a re-evaluation of Hypothesis 1, see Appendix I.1.

- For a re-evaluation of Hypothesis 2, see Appendix I.2.

- For a re-evaluation of Hypothesis 3, see Appendix I.3. 
I.1 Re-evaluating Hypothesis 1 after controlling for trust in the government 
Table I.1: Logistic regressions on the effect of recent state repression on adopting stay-athome orders (controlling for trust in government)

\begin{tabular}{|c|c|c|c|c|c|c|c|c|c|c|}
\hline & \multicolumn{8}{|c|}{ Adoption of a stay-at-home order } & \multirow[b]{2}{*}{$(9)$} & \multirow[b]{2}{*}{$(10)$} \\
\hline & $(1)$ & $(2)$ & $(3)$ & $(4)$ & $(5)$ & $(6)$ & $(7)$ & $(8)$ & & \\
\hline $\begin{array}{l}\mathrm{N} \text { of violent events }(\log ) \\
\text { (per one million population) }\end{array}$ & $\begin{array}{l}0.65^{* *} \\
(0.31)\end{array}$ & $\begin{array}{l}0.64^{* *} \\
(0.30)\end{array}$ & $\begin{array}{c}0.39 \\
(0.33)\end{array}$ & $\begin{array}{l}0.68^{* *} \\
(0.31)\end{array}$ & $\begin{array}{l}0.65^{* *} \\
(0.31)\end{array}$ & & & & & \\
\hline Human Rights Protection Score & & & & & & $\begin{array}{c}-0.74^{* * *} \\
\quad(0.24)\end{array}$ & $\begin{array}{c}-0.71^{* * *} \\
(0.22)\end{array}$ & $\begin{array}{c}-0.63^{* * *} \\
(0.23)\end{array}$ & $\begin{array}{c}-0.70^{* * * *} \\
(0.22)\end{array}$ & $\begin{array}{c}-0.73^{* * *} \\
(0.23)\end{array}$ \\
\hline $\begin{array}{l}\text { Trust in government } \\
\text { (imputed 1) }\end{array}$ & $\begin{array}{c}-0.97^{* *} \\
(0.40)\end{array}$ & & & & & $\begin{array}{c}-0.85^{* * *} \\
(0.31)\end{array}$ & & & & \\
\hline $\begin{array}{l}\text { Trust in government } \\
\text { (imputed 2) }\end{array}$ & & $\begin{array}{c}0.05 \\
(0.36)\end{array}$ & & & & & $\begin{array}{c}0.05 \\
(0.29)\end{array}$ & & & \\
\hline $\begin{array}{l}\text { Trust in government } \\
\text { (imputed } 3 \text { ) }\end{array}$ & & & $\begin{array}{c}-0.85^{* * *} \\
(0.30)\end{array}$ & & & & & $\begin{array}{c}-0.62^{* * *} \\
(0.22)\end{array}$ & & \\
\hline $\begin{array}{l}\text { Trust in government } \\
\text { (imputed 4) }\end{array}$ & & & & $\begin{array}{l}0.24 \\
(0.36)\end{array}$ & & & & & $\begin{array}{l}-0.38 \\
(0.30)\end{array}$ & \\
\hline $\begin{array}{l}\text { Trust in government } \\
\text { (imputed 5) }\end{array}$ & & & & & $\begin{array}{l}-0.45 \\
(0.37)\end{array}$ & & & & & $\begin{array}{l}-0.42 \\
(0.29)\end{array}$ \\
\hline Democracy score (V-Dem) & $\begin{array}{l}-0.50 \\
(1.65)\end{array}$ & $\begin{array}{c}1.49 \\
(1.63)\end{array}$ & $\begin{array}{c}0.11 \\
(1.54)\end{array}$ & $\begin{array}{l}1.90 \\
(1.64)\end{array}$ & $\begin{array}{c}0.84 \\
(1.52)\end{array}$ & $\begin{array}{c}1.86 \\
(1.48)\end{array}$ & $\begin{array}{l}3.48^{* *} \\
(1.58)\end{array}$ & $\begin{array}{l}2.49^{*} \\
(1.45)\end{array}$ & $\begin{array}{l}2.58^{*} \\
(1.50)\end{array}$ & $\begin{array}{l}2.88^{* *} \\
(1.43)\end{array}$ \\
\hline State Capacity & $\begin{array}{c}0.93 \\
(0.70)\end{array}$ & $\begin{array}{c}0.08 \\
(0.64)\end{array}$ & $\begin{array}{c}0.68 \\
(0.66)\end{array}$ & $\begin{array}{l}-0.04 \\
(0.63)\end{array}$ & $\begin{array}{c}0.62 \\
(0.73)\end{array}$ & $\begin{array}{c}0.74 \\
(0.57)\end{array}$ & $\begin{array}{l}-0.13 \\
(0.53)\end{array}$ & $\begin{array}{c}0.35 \\
(0.51)\end{array}$ & $\begin{array}{c}0.22 \\
(0.54)\end{array}$ & $\begin{array}{c}0.37 \\
(0.58)\end{array}$ \\
\hline $\begin{array}{l}\text { Intrastate Armed Conflict } \\
\text { (Historical) }\end{array}$ & $\begin{array}{c}0.48 \\
(0.55)\end{array}$ & $\begin{array}{c}0.92 \\
(0.60)\end{array}$ & $\begin{array}{c}0.55 \\
(0.55)\end{array}$ & $\begin{array}{l}0.93^{*} \\
(0.52)\end{array}$ & $\begin{array}{l}0.89^{*} \\
(0.52)\end{array}$ & $\begin{array}{c}0.49 \\
(0.49)\end{array}$ & $\begin{array}{c}0.75 \\
(0.50)\end{array}$ & $\begin{array}{c}0.44 \\
(0.49)\end{array}$ & $\begin{array}{c}0.71 \\
(0.47)\end{array}$ & $\begin{array}{c}0.72 \\
(0.47)\end{array}$ \\
\hline GDP per capita (log) & $\begin{array}{l}0.79^{*} \\
(0.47)\end{array}$ & $\begin{array}{c}0.68 \\
(0.46)\end{array}$ & $\begin{array}{c}0.65 \\
(0.47)\end{array}$ & $\begin{array}{c}0.68 \\
(0.46)\end{array}$ & $\begin{array}{c}0.65 \\
(0.45)\end{array}$ & $\begin{array}{c}0.39 \\
(0.38)\end{array}$ & $\begin{array}{c}0.34 \\
(0.38)\end{array}$ & $\begin{array}{c}0.37 \\
(0.39)\end{array}$ & $\begin{array}{c}0.40 \\
(0.38)\end{array}$ & $\begin{array}{c}0.37 \\
(0.38)\end{array}$ \\
\hline GDP Annual Growth & $\begin{array}{c}0.01 \\
(0.08)\end{array}$ & $\begin{array}{c}0.01 \\
(0.08)\end{array}$ & $\begin{array}{c}0.03 \\
(0.08)\end{array}$ & $\begin{array}{l}0.003 \\
(0.08)\end{array}$ & $\begin{array}{l}-0.01 \\
(0.08)\end{array}$ & $\begin{array}{l}-0.09 \\
(0.07)\end{array}$ & $\begin{array}{l}-0.07 \\
(0.07)\end{array}$ & $\begin{array}{l}-0.05 \\
(0.07)\end{array}$ & $\begin{array}{l}-0.07 \\
(0.07)\end{array}$ & $\begin{array}{l}-0.09 \\
(0.07)\end{array}$ \\
\hline Population Density ('000) & $\begin{array}{c}3.02 \\
(1.96)\end{array}$ & $\begin{array}{c}1.94 \\
(1.70)\end{array}$ & $\begin{array}{l}1.87 \\
(1.72)\end{array}$ & $\begin{array}{l}2.19 \\
(1.71)\end{array}$ & $\begin{array}{l}1.64 \\
(1.64)\end{array}$ & $\begin{array}{c}0.36 \\
(0.45)\end{array}$ & $\begin{array}{c}0.36 \\
(0.38)\end{array}$ & $\begin{array}{c}0.34 \\
(0.38)\end{array}$ & $\begin{array}{c}0.33 \\
(0.38)\end{array}$ & $\begin{array}{c}0.32 \\
(0.36)\end{array}$ \\
\hline $\begin{array}{l}\text { Population aged } 70 \\
\text { or older (percentage) }\end{array}$ & $\begin{array}{c}-0.41^{* * *} \\
(0.15)\end{array}$ & $\begin{array}{c}-0.32^{* *} \\
(0.14)\end{array}$ & $\begin{array}{c}-0.45^{* * *} \\
(0.15)\end{array}$ & $\begin{array}{c}-0.31^{* *} \\
(0.14)\end{array}$ & $\begin{array}{c}-0.37^{* *} \\
(0.15)\end{array}$ & $\begin{array}{c}-0.22^{* *} \\
(0.11)\end{array}$ & $\begin{array}{l}-0.13 \\
(0.11)\end{array}$ & $\begin{array}{c}-0.25^{* *} \\
(0.12)\end{array}$ & $\begin{array}{l}-0.17 \\
(0.11)\end{array}$ & $\begin{array}{c}-0.20^{*} \\
(0.11)\end{array}$ \\
\hline Diabetes prevalence & $\begin{array}{c}0.18 \\
(0.11)\end{array}$ & $\begin{array}{l}0.19^{*} \\
(0.11)\end{array}$ & $\begin{array}{l}0.20^{*} \\
(0.12)\end{array}$ & $\begin{array}{l}0.18^{*} \\
(0.11)\end{array}$ & $\begin{array}{l}0.20^{*} \\
(0.11)\end{array}$ & $\begin{array}{l}0.22^{* *} \\
(0.09)\end{array}$ & $\begin{array}{c}0.26^{* * *} \\
(0.09)\end{array}$ & $\begin{array}{c}0.25^{* * *} \\
(0.09)\end{array}$ & $\begin{array}{c}0.26^{* * *} \\
(0.09)\end{array}$ & $\begin{array}{c}0.25^{* * *} \\
(0.09)\end{array}$ \\
\hline Cardiovascular death rate & $\begin{array}{l}0.01^{* * *} \\
(0.003)\end{array}$ & $\begin{array}{c}0.01^{* *} \\
(0.003)\end{array}$ & $\begin{array}{l}0.01^{* * *} \\
(0.003)\end{array}$ & $\begin{array}{c}0.01^{* *} \\
(0.003)\end{array}$ & $\begin{array}{l}0.01^{* * *} \\
(0.003)\end{array}$ & $\begin{array}{c}0.01^{* *} \\
(0.002)\end{array}$ & $\begin{array}{l}0.004^{*} \\
(0.002)\end{array}$ & $\begin{array}{c}0.01^{* *} \\
(0.002)\end{array}$ & $\begin{array}{c}0.01^{* *} \\
(0.002)\end{array}$ & $\begin{array}{c}0.01^{* *} \\
(0.003)\end{array}$ \\
\hline Constant & $\begin{array}{c}-8.29^{*} \\
(4.50)\end{array}$ & $\begin{array}{c}-9.34^{* *} \\
(4.46)\end{array}$ & $\begin{array}{c}-7.69^{*} \\
(4.55)\end{array}$ & $\begin{array}{c}-9.61^{* *} \\
(4.43)\end{array}$ & $\begin{array}{c}-8.67^{* *} \\
(4.38)\end{array}$ & $\begin{array}{l}-4.80 \\
(3.62)\end{array}$ & $\begin{array}{c}-6.42^{*} \\
(3.61)\end{array}$ & $\begin{array}{l}-5.61 \\
(3.66)\end{array}$ & $\begin{array}{c}-6.33^{*} \\
(3.57)\end{array}$ & $\begin{array}{c}-6.21^{*} \\
(3.56)\end{array}$ \\
\hline Region FE & Yes & Yes & Yes & Yes & Yes & Yes & Yes & Yes & Yes & Yes \\
\hline Observations & 135 & 135 & 135 & 135 & 135 & 178 & 178 & 178 & 178 & 178 \\
\hline
\end{tabular}

${ }^{*} \mathrm{p}<0.1 ;{ }^{* *} \mathrm{p}<0.05 ;{ }^{* * *} \mathrm{p}<0.01$. Standard errors in parenthesis. Region-Fixed Effects include: Africa, Asia, Europe, North America, South America, and Oceania. 
I.2 Re-evaluating Hypothesis 2 after controlling for trust in the government 
Table I.2: Cox proportional hazards models of estimating the effect of state repression on the time to adopting a stay-at-home order (controlling for trust in government)

\begin{tabular}{|c|c|c|c|c|c|c|c|c|c|c|}
\hline & \multicolumn{10}{|c|}{ Number of days since the first COVID-19 case until stay-at-home order } \\
\hline & (1) & $(2)$ & $(3)$ & $(4)$ & $(5)$ & (6) & (7) & (8) & (9) & $(10)$ \\
\hline $\begin{array}{l}\mathrm{N} \text { of violent events }(\mathrm{log}) \\
\text { (per one million population) }\end{array}$ & $\begin{array}{c}0.50^{* * *} \\
(0.13)\end{array}$ & $\begin{array}{c}0.47^{* * *} \\
(0.12)\end{array}$ & $\begin{array}{c}0.36^{* * *} \\
(0.13)\end{array}$ & $\begin{array}{c}0.45^{* * *} \\
(0.12)\end{array}$ & $\begin{array}{c}0.45^{* * *} \\
(0.12)\end{array}$ & & & & & \\
\hline Human Rights Protection Score & & & & & & $\begin{array}{c}-0.27^{* *} \\
(0.11)\end{array}$ & $\begin{array}{c}-0.29^{* * *} \\
(0.11)\end{array}$ & $\begin{array}{c}-0.21^{*} \\
(0.11)\end{array}$ & $\begin{array}{c}-0.29^{* * *} \\
(0.11)\end{array}$ & $\begin{array}{c}-0.29^{* * *} \\
(0.11)\end{array}$ \\
\hline $\begin{array}{l}\text { Trust in government } \\
\text { (imputed } 1 \text { ) }\end{array}$ & $\begin{array}{c}-0.53^{* * *} \\
(0.19)\end{array}$ & & & & & $\begin{array}{c}-0.48^{* * *} \\
(0.17)\end{array}$ & & & & \\
\hline $\begin{array}{l}\text { Trust in government } \\
\text { (imputed 2) }\end{array}$ & & $\begin{array}{l}-0.21 \\
(0.18)\end{array}$ & & & & & $\begin{array}{l}-0.09 \\
(0.15)\end{array}$ & & & \\
\hline $\begin{array}{l}\text { Trust in government } \\
\text { (imputed } 3 \text { ) }\end{array}$ & & & $\begin{array}{c}-0.40^{* * * *} \\
(0.14)\end{array}$ & & & & & $\begin{array}{c}-0.42^{* * *} \\
(0.13)\end{array}$ & & \\
\hline $\begin{array}{l}\text { Trust in government } \\
\text { (imputed } 4 \text { ) }\end{array}$ & & & & $\begin{array}{l}-0.05 \\
(0.17)\end{array}$ & & & & & $\begin{array}{l}-0.23 \\
(0.16)\end{array}$ & \\
\hline $\begin{array}{l}\text { Trust in government } \\
\text { (imputed 5) }\end{array}$ & & & & & $\begin{array}{l}-0.12 \\
(0.17)\end{array}$ & & & & & $\begin{array}{l}-0.05 \\
(0.16)\end{array}$ \\
\hline Democracy score (V-Dem) & $\begin{array}{l}-0.35 \\
(0.78)\end{array}$ & $\begin{array}{c}0.30 \\
(0.77)\end{array}$ & $\begin{array}{c}0.36 \\
(0.71)\end{array}$ & $\begin{array}{c}0.62 \\
(0.74)\end{array}$ & $\begin{array}{l}0.58 \\
(0.72)\end{array}$ & $\begin{array}{l}0.68 \\
(0.75)\end{array}$ & $\begin{array}{l}1.35^{*} \\
(0.77)\end{array}$ & $\begin{array}{c}0.98 \\
(0.72)\end{array}$ & $\begin{array}{c}1.18 \\
(0.74)\end{array}$ & $\begin{array}{l}1.50^{* *} \\
(0.72)\end{array}$ \\
\hline State Capacity & $\begin{array}{c}0.11 \\
(0.35)\end{array}$ & $\begin{array}{l}-0.30 \\
(0.31)\end{array}$ & $\begin{array}{l}-0.28 \\
(0.29)\end{array}$ & $\begin{array}{l}-0.43 \\
(0.30)\end{array}$ & $\begin{array}{l}-0.36 \\
(0.32)\end{array}$ & $\begin{array}{l}-0.01 \\
(0.28)\end{array}$ & $\begin{array}{l}-0.38 \\
(0.26)\end{array}$ & $\begin{array}{l}-0.24 \\
(0.25)\end{array}$ & $\begin{array}{l}-0.28 \\
(0.26)\end{array}$ & $\begin{array}{l}-0.40 \\
(0.28)\end{array}$ \\
\hline $\begin{array}{l}\text { Intrastate Armed Conflict } \\
\text { (Historical) }\end{array}$ & $\begin{array}{l}-0.04 \\
(0.26)\end{array}$ & $\begin{array}{c}0.01 \\
(0.27)\end{array}$ & $\begin{array}{l}-0.04 \\
(0.26)\end{array}$ & $\begin{array}{c}0.12 \\
(0.26)\end{array}$ & $\begin{array}{c}0.11 \\
(0.26)\end{array}$ & $\begin{array}{l}0.03 \\
(0.25)\end{array}$ & $\begin{array}{c}0.10 \\
(0.26)\end{array}$ & $\begin{array}{l}-0.06 \\
(0.25)\end{array}$ & $\begin{array}{c}0.16 \\
(0.25)\end{array}$ & $\begin{array}{c}0.14 \\
(0.25)\end{array}$ \\
\hline GDP per capita (log) & $\begin{array}{l}0.45^{* *} \\
(0.22)\end{array}$ & $\begin{array}{l}0.45^{* *} \\
(0.21)\end{array}$ & $\begin{array}{l}0.47^{* *} \\
(0.21)\end{array}$ & $\begin{array}{l}0.43^{* *} \\
(0.21)\end{array}$ & $\begin{array}{l}0.44^{* *} \\
(0.21)\end{array}$ & $\begin{array}{c}0.21 \\
(0.20)\end{array}$ & $\begin{array}{c}0.19 \\
(0.19)\end{array}$ & $\begin{array}{c}0.22 \\
(0.19)\end{array}$ & $\begin{array}{c}0.23 \\
(0.19)\end{array}$ & $\begin{array}{c}0.20 \\
(0.19)\end{array}$ \\
\hline GDP Annual Growth & $\begin{array}{c}-0.002 \\
(0.04)\end{array}$ & $\begin{array}{c}0.01 \\
(0.04)\end{array}$ & $\begin{array}{c}0.02 \\
(0.04)\end{array}$ & $\begin{array}{c}0.01 \\
(0.04)\end{array}$ & $\begin{array}{c}0.01 \\
(0.04)\end{array}$ & $\begin{array}{l}-0.03 \\
(0.03)\end{array}$ & $\begin{array}{l}-0.02 \\
(0.03)\end{array}$ & $\begin{array}{l}-0.01 \\
(0.03)\end{array}$ & $\begin{array}{c}-0.02 \\
(0.03)\end{array}$ & $\begin{array}{l}-0.02 \\
(0.03)\end{array}$ \\
\hline Population Density ('000) & $\begin{array}{l}0.74^{*} \\
(0.44)\end{array}$ & $\begin{array}{c}0.73 \\
(0.48)\end{array}$ & $\begin{array}{c}0.69 \\
(0.49)\end{array}$ & $\begin{array}{c}0.59 \\
(0.47)\end{array}$ & $\begin{array}{c}0.58 \\
(0.48)\end{array}$ & $\begin{array}{c}0.17 \\
(0.13)\end{array}$ & $\begin{array}{c}0.18 \\
(0.14)\end{array}$ & $\begin{array}{c}0.18 \\
(0.14)\end{array}$ & $\begin{array}{c}0.18 \\
(0.14)\end{array}$ & $\begin{array}{c}0.18 \\
(0.14)\end{array}$ \\
\hline Population aged 70 & $\begin{array}{c}-0.16^{* *} \\
(0.07)\end{array}$ & $\begin{array}{c}-0.11^{*} \\
(0.07)\end{array}$ & $\begin{array}{c}-0.17^{* *} \\
(0.07)\end{array}$ & $\begin{array}{l}-0.11 \\
(0.07)\end{array}$ & $\begin{array}{c}-0.12^{*} \\
(0.07)\end{array}$ & $\begin{array}{l}-0.08 \\
(0.06)\end{array}$ & $\begin{array}{l}-0.03 \\
(0.05)\end{array}$ & $\begin{array}{l}-0.10 \\
(0.06)\end{array}$ & $\begin{array}{l}-0.05 \\
(0.06)\end{array}$ & $\begin{array}{l}-0.03 \\
(0.06)\end{array}$ \\
\hline Diabetes prevalence & $\begin{array}{l}-0.01 \\
(0.04)\end{array}$ & $\begin{array}{c}0.03 \\
(0.04)\end{array}$ & $\begin{array}{c}0.02 \\
(0.04)\end{array}$ & $\begin{array}{c}0.03 \\
(0.04)\end{array}$ & $\begin{array}{c}0.03 \\
(0.04)\end{array}$ & $\begin{array}{l}0.06^{*} \\
(0.04)\end{array}$ & $\begin{array}{c}0.09^{* * *} \\
(0.03)\end{array}$ & $\begin{array}{l}0.08^{* *} \\
(0.03)\end{array}$ & $\begin{array}{c}0.09^{* * *} \\
(0.03)\end{array}$ & $\begin{array}{c}0.09^{* * *} \\
(0.03)\end{array}$ \\
\hline Cardiovascular death rate & $\begin{array}{l}0.003^{* *} \\
(0.001)\end{array}$ & $\begin{array}{l}0.003^{* *} \\
(0.001)\end{array}$ & $\begin{array}{c}0.003^{* * *} \\
(0.001)\end{array}$ & $\begin{array}{c}0.002^{*} \\
(0.001)\end{array}$ & $\begin{array}{c}0.002^{*} \\
(0.001)\end{array}$ & $\begin{array}{c}0.002 \\
(0.001)\end{array}$ & $\begin{array}{c}0.001 \\
(0.001)\end{array}$ & $\begin{array}{c}0.002^{*} \\
(0.001)\end{array}$ & $\begin{array}{c}0.001 \\
(0.001)\end{array}$ & $\begin{array}{c}0.001 \\
(0.001)\end{array}$ \\
\hline Constant & $\begin{array}{c}-8.29^{*} \\
(4.50)\end{array}$ & $\begin{array}{c}-9.34^{* *} \\
(4.46)\end{array}$ & $\begin{array}{c}-7.69^{*} \\
(4.55)\end{array}$ & $\begin{array}{c}-9.61^{* *} \\
(4.43)\end{array}$ & $\begin{array}{c}-8.67^{* *} \\
(4.38)\end{array}$ & $\begin{array}{l}-4.80 \\
(3.62)\end{array}$ & $\begin{array}{c}-6.42^{*} \\
(3.61)\end{array}$ & $\begin{array}{l}-5.61 \\
(3.66)\end{array}$ & $\begin{array}{c}-6.33^{*} \\
(3.57)\end{array}$ & $\begin{array}{c}-6.21^{*} \\
(3.56)\end{array}$ \\
\hline Region FE & Yes & Yes & Yes & Yes & Yes & Yes & Yes & Yes & Yes & Yes \\
\hline Observations & 135 & 135 & 135 & 135 & 135 & 178 & 178 & 178 & 178 & 178 \\
\hline
\end{tabular}

${ }^{*} \mathrm{p}<0.1 ;{ }^{* *} \mathrm{p}<0.05 ;{ }^{* * *} \mathrm{p}<0.01$. Standard errors in parenthesis. Region-Fixed Effects include: Africa, Asia, Europe, North America, South America, and Oceania. 
I.3 Re-evaluating Hypothesis 3 after controlling for trust in the government 
Table I.3: OLS regressions on the effect of repression on the length of stay-at-home orders (controlling for trust in government)

\begin{tabular}{|c|c|c|c|c|c|c|c|c|c|c|}
\hline & \multicolumn{10}{|c|}{ Number of days with stay-at-home order in place (log) } \\
\hline & $(1)$ & $(2)$ & $(3)$ & $(4)$ & $(5)$ & $(6)$ & $(7)$ & $(8)$ & $(9)$ & $(10)$ \\
\hline $\begin{array}{l}\mathrm{N} \text { of violent events (log) } \\
\text { (per one million population) }\end{array}$ & $\begin{array}{c}0.44^{* * *} \\
(0.17)\end{array}$ & $\begin{array}{l}0.47^{* *} \\
(0.19)\end{array}$ & $\begin{array}{c}0.23 \\
(0.19)\end{array}$ & $\begin{array}{l}0.47^{* *} \\
(0.20)\end{array}$ & $\begin{array}{l}0.46^{* *} \\
(0.20)\end{array}$ & & & & & \\
\hline Human Rights Protection Score & & & & & & $\begin{array}{c}-0.49^{* * *} \\
(0.15)\end{array}$ & $\begin{array}{c}-0.52^{* * *} \\
(0.16)\end{array}$ & $\begin{array}{c}-0.41^{* * *} \\
\quad(0.16)\end{array}$ & $\begin{array}{c}-0.51^{* * *} \\
(0.16)\end{array}$ & $\begin{array}{c}-0.52^{* * *} \\
(0.15)\end{array}$ \\
\hline $\begin{array}{l}\text { Trust in government } \\
\text { (imputed 1) }\end{array}$ & $\begin{array}{c}-0.72^{* *} \\
(0.30)\end{array}$ & & & & & $\begin{array}{c}-0.72^{* * *} \\
(0.21)\end{array}$ & & & & \\
\hline $\begin{array}{l}\text { Trust in government } \\
\text { (imputed 2) }\end{array}$ & & $\begin{array}{l}-0.08 \\
(0.28)\end{array}$ & & & & & $\begin{array}{l}-0.07 \\
(0.24)\end{array}$ & & & \\
\hline $\begin{array}{l}\text { Trust in government } \\
\text { (imputed 3) }\end{array}$ & & & $\begin{array}{c}-0.80^{* * *} \\
(0.21)\end{array}$ & & & & & $\begin{array}{c}-0.61^{* * *} \\
(0.19)\end{array}$ & & \\
\hline $\begin{array}{l}\text { Trust in government } \\
\text { (imputed } 4 \text { ) }\end{array}$ & & & & $\begin{array}{l}-0.03 \\
(0.34)\end{array}$ & & & & & $\begin{array}{l}-0.34 \\
(0.24)\end{array}$ & \\
\hline $\begin{array}{l}\text { Trust in government } \\
\text { (imputed 5) }\end{array}$ & & & & & $\begin{array}{l}-0.37 \\
(0.32)\end{array}$ & & & & & $\begin{array}{l}-0.28 \\
(0.24)\end{array}$ \\
\hline Democracy score (V-Dem) & $\begin{array}{l}-0.21 \\
(1.27)\end{array}$ & $\begin{array}{c}0.86 \\
(1.27)\end{array}$ & $\begin{array}{c}0.02 \\
(1.24)\end{array}$ & $\begin{array}{c}0.97 \\
(1.39)\end{array}$ & $\begin{array}{c}0.56 \\
(1.33)\end{array}$ & $\begin{array}{c}0.98 \\
(1.16)\end{array}$ & $\begin{array}{l}2.42^{* *} \\
(1.19)\end{array}$ & $\begin{array}{c}1.49 \\
(1.03)\end{array}$ & $\begin{array}{l}1.79 \\
(1.24)\end{array}$ & $\begin{array}{l}2.20^{* *} \\
(1.11)\end{array}$ \\
\hline State Capacity & $\begin{array}{c}0.52 \\
(0.44)\end{array}$ & $\begin{array}{l}-0.06 \\
(0.43)\end{array}$ & $\begin{array}{c}0.32 \\
(0.42)\end{array}$ & $\begin{array}{l}-0.10 \\
(0.48)\end{array}$ & $\begin{array}{c}0.22 \\
(0.51)\end{array}$ & $\begin{array}{c}0.49 \\
(0.39)\end{array}$ & $\begin{array}{l}-0.20 \\
(0.37)\end{array}$ & $\begin{array}{c}0.20 \\
(0.33)\end{array}$ & $\begin{array}{c}0.05 \\
(0.40)\end{array}$ & $\begin{array}{c}0.03 \\
(0.42)\end{array}$ \\
\hline $\begin{array}{l}\text { Intrastate Armed Conflict } \\
\text { (Historical) }\end{array}$ & $\begin{array}{c}0.37 \\
(0.41)\end{array}$ & $\begin{array}{c}0.53 \\
(0.44)\end{array}$ & $\begin{array}{c}0.29 \\
(0.40)\end{array}$ & $\begin{array}{c}0.58 \\
(0.42)\end{array}$ & $\begin{array}{c}0.56 \\
(0.42)\end{array}$ & $\begin{array}{c}0.41 \\
(0.35)\end{array}$ & $\begin{array}{c}0.56 \\
(0.38)\end{array}$ & $\begin{array}{c}0.38 \\
(0.35)\end{array}$ & $\begin{array}{c}0.60 \\
(0.38)\end{array}$ & $\begin{array}{c}0.58 \\
(0.37)\end{array}$ \\
\hline GDP per capita (log) & $\begin{array}{c}0.50 \\
(0.35)\end{array}$ & $\begin{array}{c}0.47 \\
(0.37)\end{array}$ & $\begin{array}{c}0.49 \\
(0.34)\end{array}$ & $\begin{array}{c}0.47 \\
(0.37)\end{array}$ & $\begin{array}{c}0.47 \\
(0.36)\end{array}$ & $\begin{array}{c}0.40 \\
(0.27)\end{array}$ & $\begin{array}{c}0.42 \\
(0.28)\end{array}$ & $\begin{array}{l}0.48^{*} \\
(0.27)\end{array}$ & $\begin{array}{l}0.48^{*} \\
(0.28)\end{array}$ & $\begin{array}{c}0.44 \\
(0.28)\end{array}$ \\
\hline GDP Annual Growth & $\begin{array}{l}-0.03 \\
(0.06)\end{array}$ & $\begin{array}{l}-0.03 \\
(0.06)\end{array}$ & $\begin{array}{l}0.001 \\
(0.06)\end{array}$ & $\begin{array}{l}-0.03 \\
(0.06)\end{array}$ & $\begin{array}{l}-0.04 \\
(0.06)\end{array}$ & $\begin{array}{l}-0.09 \\
(0.05)\end{array}$ & $\begin{array}{l}-0.08 \\
(0.05)\end{array}$ & $\begin{array}{l}-0.05 \\
(0.05)\end{array}$ & $\begin{array}{l}-0.07 \\
(0.05)\end{array}$ & $\begin{array}{l}-0.09 \\
(0.05)\end{array}$ \\
\hline Population Density ('000) & $\begin{array}{c}0.75 \\
(1.26)\end{array}$ & $\begin{array}{c}0.62 \\
(0.94)\end{array}$ & $\begin{array}{c}0.65 \\
(0.81)\end{array}$ & $\begin{array}{c}0.58 \\
(0.97)\end{array}$ & $\begin{array}{c}0.48 \\
(0.86)\end{array}$ & $\begin{array}{c}0.25 \\
(0.35)\end{array}$ & $\begin{array}{c}0.26 \\
(0.54)\end{array}$ & $\begin{array}{c}0.26 \\
(0.47)\end{array}$ & $\begin{array}{c}0.24 \\
(0.53)\end{array}$ & $\begin{array}{c}0.24 \\
(0.61)\end{array}$ \\
\hline $\begin{array}{l}\text { Population aged } 70 \\
\text { (or older) }\end{array}$ & $\begin{array}{c}-0.33^{* * *} \\
(0.09)\end{array}$ & $\begin{array}{c}-0.25^{* * *} \\
(0.08)\end{array}$ & $\begin{array}{c}-0.36^{* * *} \\
(0.08)\end{array}$ & $\begin{array}{c}-0.25^{* * *} \\
(0.09)\end{array}$ & $\begin{array}{c}-0.29^{* * *} \\
(0.09)\end{array}$ & $\begin{array}{c}-0.16^{* * *} \\
(0.06)\end{array}$ & $\begin{array}{l}-0.06 \\
(0.06)\end{array}$ & $\begin{array}{c}-0.16^{* * *} \\
(0.06)\end{array}$ & $\begin{array}{l}-0.09 \\
(0.06)\end{array}$ & $\begin{array}{l}-0.09 \\
(0.06)\end{array}$ \\
\hline Diabetes prevalence & $\begin{array}{c}0.04 \\
(0.07)\end{array}$ & $\begin{array}{c}0.07 \\
(0.07)\end{array}$ & $\begin{array}{c}0.05 \\
(0.07)\end{array}$ & $\begin{array}{c}0.07 \\
(0.07)\end{array}$ & $\begin{array}{c}0.07 \\
(0.07)\end{array}$ & $\begin{array}{c}0.06 \\
(0.05)\end{array}$ & $\begin{array}{l}0.11^{* *} \\
(0.05)\end{array}$ & $\begin{array}{l}0.09^{* *} \\
(0.04)\end{array}$ & $\begin{array}{l}0.10^{* *} \\
(0.05)\end{array}$ & $\begin{array}{l}0.11^{* *} \\
(0.05)\end{array}$ \\
\hline Cardiovascular death rate & $\begin{array}{l}0.005^{* *} \\
(0.002)\end{array}$ & $\begin{array}{l}0.004^{*} \\
(0.002)\end{array}$ & $\begin{array}{c}0.005^{* * *} \\
(0.002)\end{array}$ & $\begin{array}{l}0.004^{*} \\
(0.002)\end{array}$ & $\begin{array}{l}0.004^{* *} \\
(0.002)\end{array}$ & $\begin{array}{l}0.004^{* *} \\
(0.002)\end{array}$ & $\begin{array}{l}0.003^{*} \\
(0.002)\end{array}$ & $\begin{array}{c}0.004^{* * *} \\
(0.002)\end{array}$ & $\begin{array}{l}0.004^{* *} \\
(0.002)\end{array}$ & $\begin{array}{l}0.004^{* *} \\
(0.002)\end{array}$ \\
\hline Constant & $\begin{array}{l}-2.10 \\
(3.27)\end{array}$ & $\begin{array}{l}-3.27 \\
(3.38)\end{array}$ & $\begin{array}{l}-2.28 \\
(3.33)\end{array}$ & $\begin{array}{l}-3.35 \\
(3.44)\end{array}$ & $\begin{array}{l}-3.09 \\
(3.45)\end{array}$ & $\begin{array}{l}-1.52 \\
(2.76)\end{array}$ & $\begin{array}{l}-3.39 \\
(2.76)\end{array}$ & $\begin{array}{l}-2.94 \\
(2.71)\end{array}$ & $\begin{array}{l}-3.50 \\
(2.82)\end{array}$ & $\begin{array}{l}-3.45 \\
(2.82)\end{array}$ \\
\hline Region FE & Yes & Yes & Yes & Yes & Yes & Yes & Yes & Yes & Yes & Yes \\
\hline Observations & 135 & 135 & 135 & 135 & 135 & 178 & 178 & 178 & 178 & 178 \\
\hline
\end{tabular}

${ }^{*} \mathrm{p}<0.1 ;{ }^{* *} \mathrm{p}<0.05 ;{ }^{* * *} \mathrm{p}<0.01$. Standard errors in parenthesis. Region-Fixed Effects include: Africa, Asia, Europe,

North America, South America, and Oceania. 


\section{Online Appendix to: \\ "Windows of Repression: Using COVID-19 Policies against Political Dissidents?"}

\section{Contents}

A List of countries $\quad 3$

A.1 ACLED Models . . . . . . . . . . . . . . . . . . . . . 3

A.2 Latent Human Rights Score Models . . . . . . . . . . . . . . . . 4

B Descriptive statistics $\quad 5$

B.1 ACLED Models . . . . . . . . . . . . . . . . . . . 5

B.2 Latent Human Rights Score Models . . . . . . . . . . . . . . . . . . 6

$\begin{array}{ll}\text { C Robustness Checks to Different Time-to-policy Thresholds } & 7\end{array}$

C.1 Robustness to varying time-to-policy thresholds (Summary table) $\ldots \ldots 8$

C.2 Time to policy after the 10th confirmed COVID-19 case . . . . . . . . 9

C.3 Time to policy after the 100th confirmed COVID-19 case . . . . . . . . 10

C.4 Time to policy after the 1 st confirmed COVID-19 death . . . . . . . . . . 11

C.5 Time to policy after the 10th confirmed COVID-19 death . . . . . . . . 12

$\begin{array}{ll}\text { D Robustness to Measuring Violence using a Different Time Window } & 13\end{array}$

D.1 Re-evaluating Hypothesis 1 using the last semester of 2019 to measure violence against civilians . . . . . . . . . . . . . . . . . 14

D.2 Re-evaluating Hypothesis 2 using the last semester of 2019 to measure violence against civilians . . . . . . . . . . . . . . . . . 16

D.3 Re-evaluating Hypothesis 3 using the last semester of 2019 to measure violence

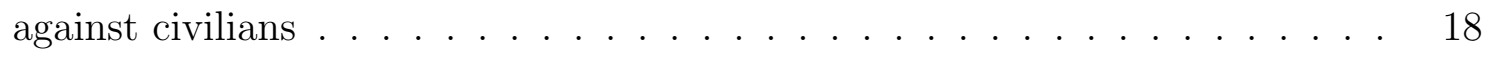


E Robustness Checks to Using All Violence Against Civilians 20

E.1 Re-evaluating Hypothesis 1 Using All Violence Against Civilians . . . . . . . 21

E.2 Re-evaluating Hypothesis 2 Using All Violence Against Civilians . . . . . . . 23

E.3 Re-evaluating Hypothesis 3 Using All Violence Against Civilians . . . . . . . 25

F Robustness Checks to Using a More Comprehensive Country Sample $\quad 27$

F.1 Re-evaluating Hypothesis 1 with an expanded country sample . . . . . . . . 29

F.2 Re-evaluating Hypothesis 2 with an expanded country sample . . . . . . . 31

F.3 Re-evaluating Hypothesis 3 with an expanded country sample . . . . . . . . 33

G Robustness to Adding an Alternative Measure of State Capacity 35

G.1 Re-evaluating Hypothesis 1 with an alternative indicator of state capacity . . 37

G.2 Re-evaluating Hypothesis 2 with an alternative indicator of state capacity . . 38

G.3 Re-evaluating Hypothesis 3 with an alternative indicator of state capacity . . 39

$\begin{array}{ll}\text { H Robustness to Police and Military Personnel } & 40\end{array}$

H.1 Re-evaluating Hypothesis 1 after controlling for army and police personnel . 41

H.2 Re-evaluating Hypothesis 2 after controlling for army and police personnel . 42

H.3 Re-evaluating Hypothesis 3 after controlling for army and police personnel . 43

I Robustness to Trust in the Government $\quad 44$

I.1 Re-evaluating Hypothesis 1 after controlling for trust in the government . . . 46

I.2 Re-evaluating Hypothesis 2 after controlling for trust in the government . . . 48

I.3 Re-evaluating Hypothesis 3 after controlling for trust in the government . . . 50 


\section{A List of countries}

\section{A.1 ACLED Models}

Afghanistan, Albania, Algeria, Angola, Antigua and Barbuda, Argentina, Armenia, Azerbaijan, Bahamas, Bahrain, Bangladesh, Barbados, Belarus, Belize, Benin, Bolivia, Bosnia and Herzegovina, Botswana, Brazil, Bulgaria, Burkina Faso, Burundi, Cambodia, Cameroon, Central African Republic, Chad, Chile, China, Colombia, Congo, Costa Rica, Croatia, Cuba, Cyprus, Czech Republic, Democratic Republic of Congo, Djibouti, Dominica, Dominican Republic, Ecuador, Egypt, El Salvador, Equatorial Guinea, Eritrea, Ethiopia, Gabon, Gambia, Georgia, Ghana, Greece, Grenada, Guatemala, Guinea, Guinea-Bissau, Guyana, Haiti, Honduras, India, Indonesia, Iran, Iraq, Israel, Jamaica, Japan, Jordan, Kazakhstan, Kenya, Kuwait, Kyrgyzstan, Laos, Lebanon, Lesotho, Liberia, Libya, Madagascar, Malawi, Malaysia, Mali, Mauritania, Mexico, Moldova, Mongolia, Montenegro, Morocco, Mozambique, Myanmar, Namibia, Nepal, Nicaragua, Niger, Nigeria, Oman, Pakistan, Palestine, Panama, Paraguay, Peru, Philippines, Qatar, Romania, Russia, Rwanda, Saint Kitts and Nevis, Saint Lucia, Saudi Arabia, Senegal, Serbia, Sierra Leone, Somalia, South Africa, South Korea, South Sudan, Sri Lanka, Sudan, Suriname, Swaziland, Syria, Taiwan, Tajikistan, Tanzania, Thailand, Togo, Trinidad and Tobago, Tunisia, Turkey, Uganda, Ukraine, United Arab Emirates, Uruguay, Uzbekistan, Venezuela, Vietnam, Yemen, Zambia, and Zimbabwe. 


\section{A.2 Latent Human Rights Score Models}

Afghanistan, Albania, Algeria, Andorra, Angola, Antigua and Barbuda, Argentina, Armenia, Australia, Austria, Azerbaijan, Bahamas, Bahrain, Bangladesh, Barbados, Belarus, Belgium, Belize, Benin, Bhutan, Bolivia, Bosnia and Herzegovina, Botswana, Brazil, Brunei, Bulgaria, Burkina Faso, Burundi, Cambodia, Cameroon, Canada, Cape Verde, Central African Republic, Chad, Chile, China, Colombia, Comoros, Costa Rica, Croatia, Cuba, Cyprus, Czech Republic, Democratic Republic of Congo, Denmark, Djibouti, Dominica, Dominican Republic, Ecuador, Egypt, El Salvador, Equatorial Guinea, Eritrea, Estonia, Ethiopia, Fiji, Finland, France, Gabon, Gambia, Georgia, Germany, Ghana, Greece, Grenada, Guatemala, Guinea, Guinea-Bissau, Guyana, Haiti, Honduras, Hungary, Iceland, India, Indonesia, Iran, Iraq, Ireland, Israel, Italy, Ivory Coast, Jamaica, Japan, Jordan, Kazakhstan, Kenya, Kosovo, Kuwait, Kyrgyzstan, Laos, Latvia, Lebanon, Lesotho, Liberia, Libya, Liechtenstein, Lithuania, Luxembourg, Madagascar, Malawi, Malaysia, Maldives, Mali, Malta, Mauritania, Mauritius, Mexico, Moldova, Monaco, Mongolia, Montenegro, Morocco, Mozambique, Myanmar, Namibia, Nepal, Netherlands, New Zealand, Nicaragua, Niger, Nigeria, North Macedonia, Norway, Oman, Pakistan, Palestine, Panama, Papua New Guinea, Paraguay, Peru, Philippines, Poland, Portugal, Qatar, Republic of the Congo, Romania, Russia, Rwanda, Saint Kitts and Nevis, Saint Lucia, San Marino, Saudi Arabia, Senegal, Serbia, Seychelles, Sierra Leone, Singapore, Slovakia, Slovenia, Somalia, South Africa, South Korea, South Sudan, Spain, Sri Lanka, Sudan, Suriname, Swaziland, Sweden, Switzerland, Syria, Taiwan, Tajikistan, Tanzania, Thailand, Timor Leste, Togo, Trinidad and Tobago, Tunisia, Turkey, Uganda, Ukraine, United Arab Emirates, United Kingdom, United States, Uruguay, Uzbekistan, Venezuela, Vietnam, Yemen, Zambia, Zimbabwe 


\section{B Descriptive statistics}

\section{B.1 ACLED Models}

Table B.1: Descriptive statistics (ACLED Models)

\begin{tabular}{|c|c|c|c|c|}
\hline Variable name & Mean & $(\mathrm{SD})$ & $\operatorname{Min} \Rightarrow \operatorname{Max}$ & $\mathrm{N}$ \\
\hline Time of policy adoption since first case (in days) & 76.8 & $(70.4)$ & $0 \Rightarrow 231$ & 135 \\
\hline Policy adoption dummy & 0.70 & $(0.46)$ & $0 \Rightarrow 1$ & 135 \\
\hline Length of policy adoption (in days) & 73.4 & $(65.5)$ & $0 \Rightarrow 178$ & 135 \\
\hline Number of events & 142.11 & $(545.58)$ & $0 \Rightarrow 5,757$ & 135 \\
\hline Number of events (per one million population) & 6.16 & $(15.52)$ & $0 \Rightarrow 118.2$ & 135 \\
\hline Democracy score (V-Dem) & 0.47 & $(0.23)$ & $0.02 \Rightarrow 0.89$ & 135 \\
\hline State Capacity & -0.38 & $(0.80)$ & $-2.45 \Rightarrow 159$ & 135 \\
\hline Intrastate Armed Conflict (Historical) & 0.59 & $(0.49)$ & $0 \Rightarrow 1$ & 135 \\
\hline GDP per capita & 13,072 & $(15,338)$ & $661.2 \Rightarrow 116,935$ & 135 \\
\hline GDP Growth & 2.61 & $(3.35)$ & $-10.8 \Rightarrow 9.43$ & 135 \\
\hline Population density & 148.5 & $(236.3)$ & $1.98 \Rightarrow 1,935.9$ & 135 \\
\hline Population aged 70 or older (\%) & 4.15 & $(3.19)$ & $0.53 \Rightarrow 18.49$ & 132 \\
\hline Diabetes prevalence & 7.78 & $(3.82)$ & $0.99 \Rightarrow 17.72$ & 133 \\
\hline Cardiovascular death rate & 279.9 & $(114.6)$ & $79.37 \Rightarrow 724.4$ & 134 \\
\hline
\end{tabular}




\section{B.2 Latent Human Rights Score Models}

Table B.2: Descriptive statistics (Human Rights Models)

\begin{tabular}{|c|c|c|c|c|}
\hline Variable name & Mean & $(\mathrm{SD})$ & $\operatorname{Min} \Rightarrow \operatorname{Max}$ & $\mathrm{N}$ \\
\hline Time of policy adoption since first case (in days) & 83.4 & $(73.2)$ & $0 \Rightarrow 231$ & 182 \\
\hline Policy adoption dummy & 0.66 & $(0.48)$ & $0 \Rightarrow 1$ & 182 \\
\hline Length of policy adoption (in days) & 64.6 & $(63.9)$ & $0 \Rightarrow 178$ & 182 \\
\hline Latent Human Rights Protection Score & 0.78 & $(1,67)$ & $-2.09 \Rightarrow 5.31$ & 182 \\
\hline Democracy score (V-Dem) & 0.54 & $(0.25)$ & $0.02 \Rightarrow 0.9$ & 177 \\
\hline State Capacity & -0.04 & $(1.01)$ & $-2.45 \Rightarrow 2.22$ & 180 \\
\hline Intrastate Armed Conflict (Historical) & 0.47 & $(0.50)$ & $0 \Rightarrow 1$ & 182 \\
\hline GDP per capita & 18,746 & $(19,635)$ & $661.2 \Rightarrow 116,935$ & 179 \\
\hline GDP Growth & 2.70 & $(3.27)$ & $-10.8 \Rightarrow 18.7$ & 181 \\
\hline Population density & 310.6 & $(1552.2)$ & $1.98 \Rightarrow 19347.5$ & 182 \\
\hline Population aged 70 or older (\%) & 5.50 & $(4.26)$ & $0.53 \Rightarrow 18.49$ & 174 \\
\hline Diabetes prevalence & 7.68 & $(3.80)$ & $0.99 \Rightarrow 22.02$ & 179 \\
\hline Cardiovascular death rate & 257.9 & $(118.0)$ & $79.37 \Rightarrow 724.4$ & 177 \\
\hline
\end{tabular}




\section{Robustness Checks to Different Time-to-policy Thresh- olds}

In this Online Appendix, we check the findings to different time-to-policy thresholds. The outcome measure in our survival plots and the Cox Proportional Hazard models rely on counting the number of days from the first COVID-19 confirmed case to the imposition of a stay-at-home order. We acknowledge that a first case might not necessarily lead to an upward trend in the number of cases in the country or may simply reflect greater testing capabilities. To alleviate this concern, we evaluate the robustness of our findings to using different time-topolicy thresholds, namely the 10th COVID-19 confirmed cases in the subsection C.2, the first 100th COVID-19 confirmed cases in the subsection C.3, the 1st COVID-19 confirmed death in the subsection C.4, and the 10th COVID-19 confirmed case in the subsection C.5. The next subsection C.1 summarizes the results of our robustness checks. In brief, they indicate that none of our main findings are sensitive to using a specific time-to-policy threshold. 


\section{C.1 Robustness to varying time-to-policy thresholds (Summary table)}

Table C.1: Cox proportional hazards models of estimating the effect of recent state repression on the timing of policy adoption with varying time-to-policy thresholds

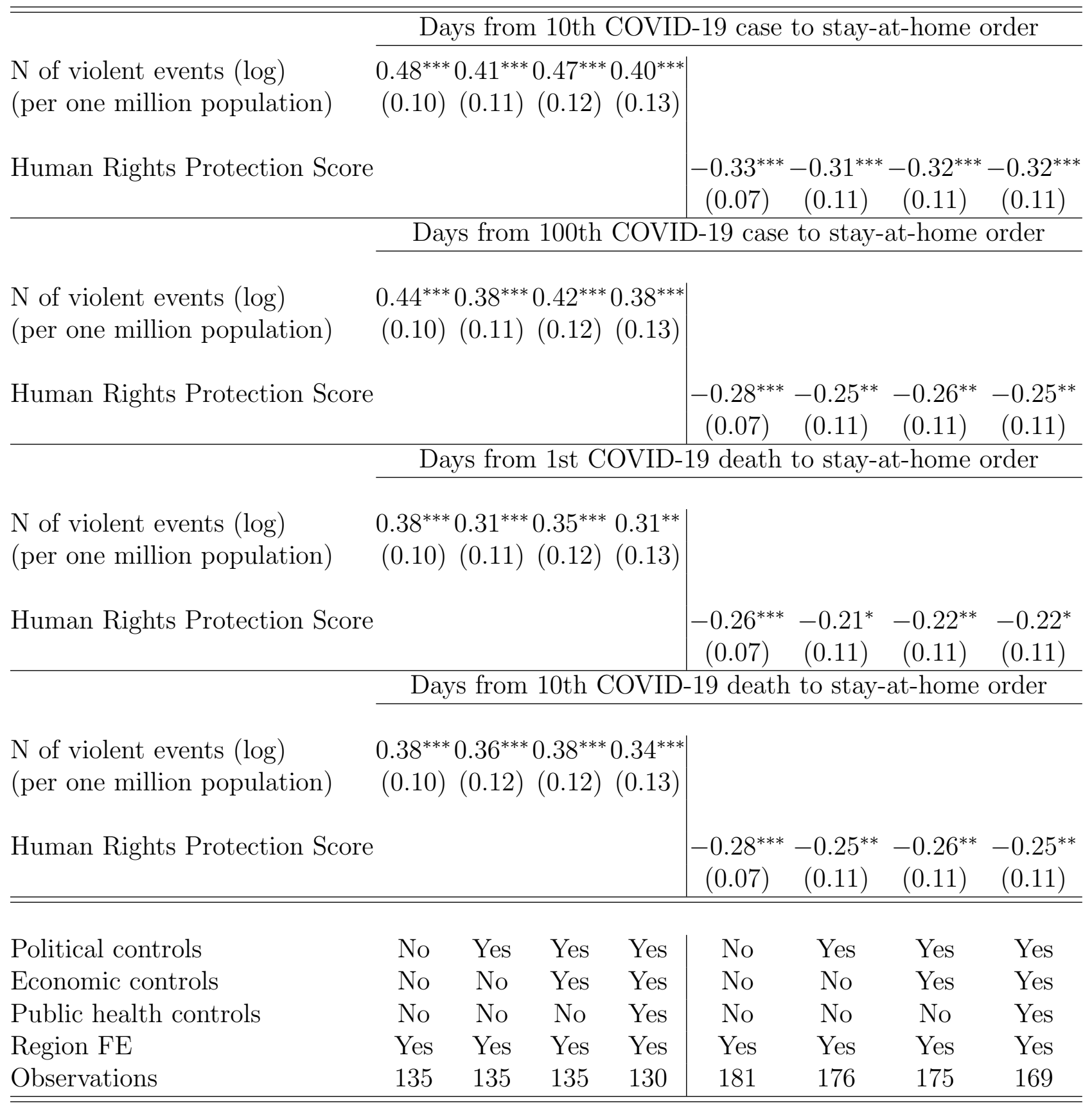

${ }^{*} \mathrm{p}<0.1 ;{ }^{* *} \mathrm{p}<0.05 ;{ }^{* * *} \mathrm{p}<0.01$. SE in parenthesis. Region-FE include: Africa, Asia, Europe, North America, and South America. See full models in the following Appendices. 


\section{C.2 Time to policy after the 10th confirmed COVID-19 case}

Table C.2: Cox proportional hazards models of estimating the effect of state repression in 2019 and human rights scores on the time to adopting a stay-at-home order (10th confirmed case)

\begin{tabular}{|c|c|c|c|c|c|c|c|c|}
\hline & \multicolumn{8}{|c|}{ Days from 10th COVID-19 confirmed case to stay-at-home order } \\
\hline & $(1)$ & $(2)$ & $(3)$ & $(4)$ & $(5)$ & $(6)$ & $(7)$ & $(8)$ \\
\hline $\begin{array}{l}\mathrm{N} \text { of violent events }(\mathrm{log}) \\
\text { (per one million population) }\end{array}$ & $\begin{array}{c}0.48^{* * *} \\
(0.10)\end{array}$ & $\begin{array}{c}0.41^{* * *} \\
(0.11)\end{array}$ & $\begin{array}{c}0.47^{* * *} \\
(0.12)\end{array}$ & $\begin{array}{c}0.40^{* * *} \\
(0.13)\end{array}$ & & & & \\
\hline Human Rights Protection Score & & & & & $\begin{array}{c}-0.33^{* * *} \\
(0.07)\end{array}$ & $\begin{array}{c}-0.31^{* * *} \\
(0.11)\end{array}$ & $\begin{array}{c}-0.32^{* * *} \\
(0.11)\end{array}$ & $\begin{array}{c}-0.32^{* * *} \\
(0.11)\end{array}$ \\
\hline Democracy score (V-Dem) & & $\begin{array}{l}-0.04 \\
(0.60)\end{array}$ & $\begin{array}{l}0.29 \\
(0.63)\end{array}$ & $\begin{array}{l}1.15 \\
(0.73)\end{array}$ & & $\begin{array}{c}0.68 \\
(0.60)\end{array}$ & $\begin{array}{l}1.15^{*} \\
(0.63)\end{array}$ & $\begin{array}{c}1.97^{* * *} \\
(0.72)\end{array}$ \\
\hline State Capacity & & $\begin{array}{l}-0.28 \\
(0.20)\end{array}$ & $\begin{array}{c}-0.65^{* * *} \\
(0.25)\end{array}$ & $\begin{array}{l}-0.37 \\
(0.28)\end{array}$ & & $\begin{array}{c}-0.33^{* *} \\
(0.17)\end{array}$ & $\begin{array}{c}-0.64^{* * *} \\
(0.21)\end{array}$ & $\begin{array}{c}-0.45^{*} \\
(0.23)\end{array}$ \\
\hline $\begin{array}{l}\text { Intrastate Armed Conflict } \\
\text { (Historical) }\end{array}$ & & $\begin{array}{l}-0.01 \\
(0.25)\end{array}$ & $\begin{array}{l}0.11 \\
(0.25)\end{array}$ & $\begin{array}{c}0.22 \\
(0.26)\end{array}$ & & $\begin{array}{c}0.07 \\
(0.24)\end{array}$ & $\begin{array}{c}0.16 \\
(0.24)\end{array}$ & $\begin{array}{l}0.20 \\
(0.25)\end{array}$ \\
\hline GDP per capita (log) & & & $\begin{array}{l}0.42^{* *} \\
(0.18)\end{array}$ & $\begin{array}{l}0.37^{*} \\
(0.21)\end{array}$ & & & $\begin{array}{l}0.33^{* *} \\
(0.16)\end{array}$ & $\begin{array}{c}0.21 \\
(0.18)\end{array}$ \\
\hline GDP Annual Growth & & & $\begin{array}{l}0.03 \\
(0.04)\end{array}$ & $\begin{array}{l}-0.01 \\
(0.04)\end{array}$ & & & $\begin{array}{l}-0.01 \\
(0.03)\end{array}$ & $\begin{array}{l}-0.03 \\
(0.03)\end{array}$ \\
\hline Population Density ('000) & & & $\begin{array}{c}0.46 \\
(0.46)\end{array}$ & $\begin{array}{c}0.70 \\
(0.46)\end{array}$ & & & $\begin{array}{c}0.22 \\
(0.14)\end{array}$ & $\begin{array}{c}0.22 \\
(0.14)\end{array}$ \\
\hline $\begin{array}{l}\text { Population aged } 70 \\
\text { or older (percentage) }\end{array}$ & & & & $\begin{array}{c}-0.13^{*} \\
(0.07)\end{array}$ & & & & $\begin{array}{l}-0.03 \\
(0.06)\end{array}$ \\
\hline Diabetes prevalence & & & & $\begin{array}{c}0.04 \\
(0.04)\end{array}$ & & & & $\begin{array}{c}0.09^{* * *} \\
(0.03)\end{array}$ \\
\hline Cardiovascular death rate & & & & $\begin{array}{l}0.002^{* *} \\
(0.001)\end{array}$ & & & & $\begin{array}{c}0.001 \\
(0.001)\end{array}$ \\
\hline Region FE & Yes & Yes & Yes & Yes & Yes & Yes & Yes & Yes \\
\hline Observations & 135 & 135 & 135 & 130 & 182 & 177 & 176 & 170 \\
\hline
\end{tabular}

${ }^{*} \mathrm{p}<0.1 ;{ }^{* *} \mathrm{p}<0.05 ;{ }^{* * *} \mathrm{p}<0.01$. Standard errors in parenthesis. Region-Fixed Effects include:

Africa, Asia, Europe, North America, South America, and Oceania. 


\section{C.3 Time to policy after the 100th confirmed COVID-19 case}

Table C.3: Cox proportional hazards models of estimating the effect of state repression in 2019 and human rights scores on the time to adopting a stay-at-home order (100th confirmed case)

\begin{tabular}{|c|c|c|c|c|c|c|c|c|}
\hline & \multicolumn{8}{|c|}{ Days from 100th COVID-19 confirmed case to stay-at-home order } \\
\hline & $(1)$ & $(2)$ & $(3)$ & $(4)$ & $(5)$ & $(6)$ & $(7)$ & $(8)$ \\
\hline $\begin{array}{l}\mathrm{N} \text { of violent events }(\mathrm{log}) \\
\text { (per one million population) }\end{array}$ & $\begin{array}{c}0.44^{* * *} \\
(0.10)\end{array}$ & $\begin{array}{l}0.38^{* * *} \\
(0.11)\end{array}$ & $\begin{array}{c}0.42^{* * *} \\
(0.12)\end{array}$ & $\begin{array}{c}0.38^{* * *} \\
(0.13)\end{array}$ & & & & \\
\hline Human Rights Protection Score & & & & & $\begin{array}{c}-0.28^{* * *} \\
(0.07)\end{array}$ & $\begin{array}{c}-0.25^{* *} \\
(0.11)\end{array}$ & $\begin{array}{c}-0.26^{* *} \\
(0.11)\end{array}$ & $\begin{array}{c}-0.25^{* *} \\
(0.11)\end{array}$ \\
\hline Democracy score (V-Dem) & & $\begin{array}{c}-0.002 \\
(0.59)\end{array}$ & $\begin{array}{c}0.31 \\
(0.63)\end{array}$ & $\begin{array}{l}1.19 \\
(0.73)\end{array}$ & & $\begin{array}{c}0.65 \\
(0.61)\end{array}$ & $\begin{array}{l}1.04^{*} \\
(0.63)\end{array}$ & $\begin{array}{l}1.85^{* * *} \\
(0.71)\end{array}$ \\
\hline State Capacity & & $\begin{array}{l}-0.21 \\
(0.20)\end{array}$ & $\begin{array}{c}-0.53^{* *} \\
(0.26)\end{array}$ & $\begin{array}{l}-0.26 \\
(0.29)\end{array}$ & & $\begin{array}{c}-0.37^{* *} \\
(0.17)\end{array}$ & $\begin{array}{c}-0.65^{* * *} \\
(0.22)\end{array}$ & $\begin{array}{c}-0.42^{*} \\
(0.25)\end{array}$ \\
\hline $\begin{array}{l}\text { Intrastate Armed Conflict } \\
\text { (Historical) }\end{array}$ & & $\begin{array}{l}-0.02 \\
(0.24)\end{array}$ & $\begin{array}{c}0.08 \\
(0.25)\end{array}$ & $\begin{array}{c}0.15 \\
(0.25)\end{array}$ & & $\begin{array}{l}-0.02 \\
(0.23)\end{array}$ & $\begin{array}{c}0.07 \\
(0.24)\end{array}$ & $\begin{array}{c}0.07 \\
(0.24)\end{array}$ \\
\hline GDP per capita $(\log )$ & & & $\begin{array}{l}0.34^{*} \\
(0.17)\end{array}$ & $\begin{array}{c}0.27 \\
(0.21)\end{array}$ & & & $\begin{array}{l}0.28^{*} \\
(0.17)\end{array}$ & $\begin{array}{c}0.12 \\
(0.19)\end{array}$ \\
\hline GDP Annual Growth & & & $\begin{array}{c}0.02 \\
(0.04)\end{array}$ & $\begin{array}{l}-0.01 \\
(0.04)\end{array}$ & & & $\begin{array}{c}0.0000 \\
(0.03)\end{array}$ & $\begin{array}{l}-0.02 \\
(0.03)\end{array}$ \\
\hline Population Density ('000) & & & $\begin{array}{c}0.39 \\
(0.43)\end{array}$ & $\begin{array}{c}0.57 \\
(0.43)\end{array}$ & & & $\begin{array}{l}0.18 \\
(0.14)\end{array}$ & $\begin{array}{c}0.16 \\
(0.14)\end{array}$ \\
\hline $\begin{array}{l}\text { Population aged } 70 \\
\text { or older (percentage) }\end{array}$ & & & & $\begin{array}{l}-0.11 \\
(0.07)\end{array}$ & & & & $\begin{array}{l}-0.04 \\
(0.06)\end{array}$ \\
\hline Diabetes prevalence & & & & $\begin{array}{c}0.05 \\
(0.04)\end{array}$ & & & & $\begin{array}{c}0.10^{* * *} \\
(0.03)\end{array}$ \\
\hline Cardiovascular death rate & & & & $\begin{array}{l}0.003^{* *} \\
(0.001)\end{array}$ & & & & $\begin{array}{c}0.001 \\
(0.001)\end{array}$ \\
\hline Region FE & Yes & Yes & Yes & Yes & Yes & Yes & Yes & Yes \\
\hline Observations & 135 & 135 & 135 & 130 & 181 & 176 & 175 & 169 \\
\hline
\end{tabular}

${ }^{*} \mathrm{p}<0.1 ;{ }^{* *} \mathrm{p}<0.05 ;{ }^{* *} \mathrm{p}<0.01$. Standard errors in parenthesis. Region-Fixed Effects include:

Africa, Asia, Europe, North America, South America, and Oceania. 


\section{C.4 Time to policy after the 1st confirmed COVID-19 death}

Table C.4: Cox proportional hazards models of estimating the effect of state repression in 2019 and human rights scores on the time to adopting a stay-at-home order (1st death)

\begin{tabular}{|c|c|c|c|c|c|c|c|c|}
\hline & \multicolumn{8}{|c|}{ Days from 1st COVID-19 confirmed death to stay-at-home ordel } \\
\hline & $(1)$ & $(2)$ & (3) & $(4)$ & (5) & (6) & $(7)$ & (8) \\
\hline $\begin{array}{l}\mathrm{N} \text { of violent events }(\log ) \\
\text { (per one million population) }\end{array}$ & $\begin{array}{r}0.38^{* * *} \\
(0.10)\end{array}$ & $\begin{array}{c}0.31^{* * *} \\
(0.11)\end{array}$ & $\begin{array}{c}0.35^{* * *} \\
(0.12)\end{array}$ & $\begin{array}{l}0.31^{* *} \\
(0.13)\end{array}$ & & & & \\
\hline Human Rights Protection Score & & & & & $\begin{array}{l}-0.26^{* * *} \\
(0.07)\end{array}$ & $\begin{array}{l}-0.21^{*} \\
(0.11)\end{array}$ & $\begin{array}{c}-0.22^{* *} \\
(0.11)\end{array}$ & $\begin{array}{r}-0.22^{*} \\
(0.11)\end{array}$ \\
\hline Democracy score (V-Dem) & & $\begin{array}{l}-0.07 \\
(0.60)\end{array}$ & $\begin{array}{c}0.19 \\
(0.63)\end{array}$ & $\begin{array}{c}1.04 \\
(0.74)\end{array}$ & & $\begin{array}{c}0.41 \\
(0.61)\end{array}$ & $\begin{array}{c}0.78 \\
(0.64)\end{array}$ & $\begin{array}{l}1.51^{* *} \\
(0.72)\end{array}$ \\
\hline State Capacity & & $\begin{array}{l}-0.23 \\
(0.20)\end{array}$ & $\begin{array}{c}-0.52^{* *} \\
(0.25)\end{array}$ & $\begin{array}{l}-0.27 \\
(0.28)\end{array}$ & & $\begin{array}{c}-0.35^{* *} \\
(0.17)\end{array}$ & $\begin{array}{c}-0.61^{* * *} \\
(0.22)\end{array}$ & $\begin{array}{l}-0.39 \\
(0.24)\end{array}$ \\
\hline $\begin{array}{l}\text { Intrastate Armed Conflict } \\
\text { (Historical) }\end{array}$ & & $\begin{array}{c}0.04 \\
(0.25)\end{array}$ & $\begin{array}{c}0.11 \\
(0.25)\end{array}$ & $\begin{array}{c}0.19 \\
(0.25)\end{array}$ & & $\begin{array}{c}-0.003 \\
(0.24)\end{array}$ & $\begin{array}{l}0.07 \\
(0.24)\end{array}$ & $\begin{array}{c}0.10 \\
(0.25)\end{array}$ \\
\hline GDP per capita $(\log )$ & & & $\begin{array}{l}0.32^{*} \\
(0.17)\end{array}$ & $\begin{array}{c}0.27 \\
(0.21)\end{array}$ & & & $\begin{array}{l}0.28^{*} \\
(0.16)\end{array}$ & $\begin{array}{c}0.14 \\
(0.19)\end{array}$ \\
\hline GDP Annual Growth & & & $\begin{array}{c}0.02 \\
(0.04)\end{array}$ & $\begin{array}{l}-0.02 \\
(0.04)\end{array}$ & & & $\begin{array}{l}0.003 \\
(0.03)\end{array}$ & $\begin{array}{l}-0.01 \\
(0.03)\end{array}$ \\
\hline Population Density ('000) & & & $\begin{array}{c}0.28 \\
(0.47)\end{array}$ & $\begin{array}{c}0.44 \\
(0.47)\end{array}$ & & & $\begin{array}{c}0.17 \\
(0.15)\end{array}$ & $\begin{array}{c}0.14 \\
(0.15)\end{array}$ \\
\hline $\begin{array}{l}\text { Population aged } 70 \\
\text { or older (percentage) }\end{array}$ & & & & $\begin{array}{l}-0.11 \\
(0.07)\end{array}$ & & & & $\begin{array}{l}-0.03 \\
(0.06)\end{array}$ \\
\hline Diabetes prevalence & & & & $\begin{array}{c}0.04 \\
(0.04)\end{array}$ & & & & $\begin{array}{r}0.09^{* * *} \\
(0.03)\end{array}$ \\
\hline Cardiovascular death rate & & & & $\begin{array}{c}0.002 \\
(0.001)\end{array}$ & & & & $\begin{array}{c}0.001 \\
(0.001)\end{array}$ \\
\hline & Yes & Yes & Yes & Yes & Yes & Yes & Yes & Yes \\
\hline Observations & 135 & 135 & 135 & 130 & 181 & 176 & 175 & 169 \\
\hline
\end{tabular}

${ }^{*} \mathrm{p}<0.1 ;{ }^{* *} \mathrm{p}<0.05 ;{ }^{* * *} \mathrm{p}<0.01$. Standard errors in parenthesis. Region-Fixed Effects include:

Africa, Asia, Europe, North America, South America, and Oceania. 


\section{C.5 Time to policy after the 10th confirmed COVID-19 death}

Table C.5: Cox proportional hazards models of estimating the effect of state repression in 2019 and human rights scores on the time to adopting a stay-at-home order (10th death)

\begin{tabular}{|c|c|c|c|c|c|c|c|c|}
\hline & \multicolumn{8}{|c|}{ Days from 10th COVID-19 confirmed death to stay-at-home order } \\
\hline & $(1)$ & $(2)$ & $(3)$ & $(4)$ & $(5)$ & (6) & $(7)$ & $(8)$ \\
\hline $\begin{array}{l}\mathrm{N} \text { of violent events }(\mathrm{log}) \\
\text { (per one million population) }\end{array}$ & $\begin{array}{c}0.38^{* * *} \\
(0.10)\end{array}$ & $\begin{array}{c}0.36^{* * *} \\
(0.12)\end{array}$ & $\begin{array}{c}0.38^{* * *} \\
(0.12)\end{array}$ & $\begin{array}{c}0.34^{* * *} \\
(0.13)\end{array}$ & & & & \\
\hline Human Rights Protection Score & & & & & $\begin{array}{c}-0.28^{* * *} \\
(0.07)\end{array}$ & $\begin{array}{c}-0.25^{* *} \\
(0.11)\end{array}$ & $\begin{array}{c}-0.26^{* *} \\
(0.11)\end{array}$ & $\begin{array}{c}-0.25^{* *} \\
(0.11)\end{array}$ \\
\hline Democracy score (V-Dem) & & $\begin{array}{l}-0.12 \\
(0.61)\end{array}$ & $\begin{array}{c}0.22 \\
(0.64)\end{array}$ & $\begin{array}{c}1.09 \\
(0.74)\end{array}$ & & $\begin{array}{c}0.67 \\
(0.62)\end{array}$ & $\begin{array}{l}1.13^{*} \\
(0.65)\end{array}$ & $\begin{array}{l}1.57^{* *} \\
(0.70)\end{array}$ \\
\hline State Capacity & & $\begin{array}{l}-0.07 \\
(0.20)\end{array}$ & $\begin{array}{l}-0.39 \\
(0.26)\end{array}$ & $\begin{array}{l}-0.07 \\
(0.30)\end{array}$ & & $\begin{array}{l}-0.17 \\
(0.17)\end{array}$ & $\begin{array}{c}-0.47^{* *} \\
(0.22)\end{array}$ & $\begin{array}{l}-0.28 \\
(0.24)\end{array}$ \\
\hline $\begin{array}{l}\text { Intrastate Armed Conflict } \\
\text { (Historical) }\end{array}$ & & $\begin{array}{l}-0.04 \\
(0.24)\end{array}$ & $\begin{array}{c}0.05 \\
(0.25)\end{array}$ & $\begin{array}{c}0.10 \\
(0.25)\end{array}$ & & $\begin{array}{l}-0.06 \\
(0.24)\end{array}$ & $\begin{array}{c}0.02 \\
(0.24)\end{array}$ & $\begin{array}{l}-0.01 \\
(0.24)\end{array}$ \\
\hline GDP per capita (log) & & & $\begin{array}{l}0.30^{*} \\
(0.17)\end{array}$ & $\begin{array}{c}0.21 \\
(0.21)\end{array}$ & & & $\begin{array}{l}0.29^{*} \\
(0.16)\end{array}$ & $\begin{array}{c}0.13 \\
(0.19)\end{array}$ \\
\hline GDP Annual Growth & & & $\begin{array}{c}0.01 \\
(0.04)\end{array}$ & $\begin{array}{l}-0.02 \\
(0.04)\end{array}$ & & & $\begin{array}{c}-0.003 \\
(0.03)\end{array}$ & $\begin{array}{l}-0.02 \\
(0.03)\end{array}$ \\
\hline Population Density ('000) & & & $\begin{array}{c}0.69 \\
(0.47)\end{array}$ & $\begin{array}{l}0.81^{*} \\
(0.46)\end{array}$ & & & $\begin{array}{l}0.27^{*} \\
(0.14)\end{array}$ & $\begin{array}{l}0.24^{*} \\
(0.14)\end{array}$ \\
\hline $\begin{array}{l}\text { Population aged } 70 \\
\text { or older (percentage) }\end{array}$ & & & & $\begin{array}{c}-0.13^{*} \\
(0.07)\end{array}$ & & & & $\begin{array}{l}-0.04 \\
(0.06)\end{array}$ \\
\hline Diabetes prevalence & & & & $\begin{array}{l}0.05 \\
(0.04)\end{array}$ & & & & $\begin{array}{l}0.08^{* *} \\
(0.03)\end{array}$ \\
\hline Cardiovascular death rate & & & & $\begin{array}{l}0.002^{*} \\
(0.001)\end{array}$ & & & & $\begin{array}{l}0.0005 \\
(0.001)\end{array}$ \\
\hline Region FE & Yes & Yes & Yes & Yes & Yes & Yes & Yes & Yes \\
\hline Observations & 135 & 135 & 135 & 130 & 181 & 176 & 175 & 169 \\
\hline
\end{tabular}

${ }^{*} \mathrm{p}<0.1 ;{ }^{* *} \mathrm{p}<0.05 ;{ }^{* * *} \mathrm{p}<0.01$. Standard errors in parenthesis. Region-Fixed Effects include:

Africa, Asia, Europe, North America, South America, and Oceania. 


\section{Robustness to Measuring Violence using a Different Time Window}

In this Appendix, we evaluate the robustness of our findings to the time windows used to measure violence against civilians before the outbreak in the ACLED models. For our main ACLED models, we measure a governments' recent record of violence using the number of violent events against civilians in 2019. However, it may be more precise to only measure violence that took place immediately before the pandemic outbreak. Indeed, using all of 2019, rather than the last six months is an arbitrary decision. Hence, in this Online Appendix, we examine the robustness of our findings using different time windows for building that measure. We evaluate our findings when using the last semester of 2019 as the time window to build our indicator of state repression against civilians. Because the specific period to build our measure is rather arbitrary, we re-evaluate the findings of our three hypotheses to using the six months preceding the first confirmed global case - July through December of 2019 - in our measure of violence against civilians:

- For a re-evaluation of Hypothesis 1, see Appendix D.1.

- For a re-evaluation of Hypothesis 2, see Appendix D.2.

- For a re-evaluation of Hypothesis 3, see Appendix D.3.

These models show that our main findings remain substantively unaltered with regards to our hypotheses when using the last semester of 2019 - rather than the entire year of 2019 - as the time window to measure state-led violence against civilians. Note also that this robustness check is irrelevant for our models based on the latent human rights protection scores. 
D.1 Re-evaluating Hypothesis 1 using the last semester of 2019 to measure violence against civilians 
Table D.1: Logistic regressions on the effect of recent state repression on adopting stay-athome orders

\begin{tabular}{|c|c|c|c|c|}
\hline & \multicolumn{4}{|c|}{ Adoption of a stay-at-home order } \\
\hline & (1) & (2) & (3) & (4) \\
\hline $\begin{array}{l}\mathrm{N} \text { of violent events }(\mathrm{log}) \\
\text { (per one million population) }\end{array}$ & $\begin{array}{c}0.81^{* * *} \\
(0.30)\end{array}$ & $\begin{array}{l}0.69^{* *} \\
(0.32)\end{array}$ & $\begin{array}{l}0.83^{* *} \\
(0.34)\end{array}$ & $\begin{array}{l}0.78^{* *} \\
(0.39)\end{array}$ \\
\hline Democracy score (V-Dem) & & $\begin{array}{l}-0.65 \\
(1.12)\end{array}$ & $\begin{array}{c}0.09 \\
(1.19)\end{array}$ & $\begin{array}{c}1.70 \\
(1.49)\end{array}$ \\
\hline State Capacity & & $\begin{array}{l}-0.04 \\
(0.36)\end{array}$ & $\begin{array}{l}-0.80 \\
(0.53)\end{array}$ & $\begin{array}{c}0.08 \\
(0.60)\end{array}$ \\
\hline $\begin{array}{l}\text { Intrastate Armed Conflict } \\
\text { (Historical) }\end{array}$ & & $\begin{array}{c}0.44 \\
(0.45)\end{array}$ & $\begin{array}{c}0.59 \\
(0.47)\end{array}$ & $\begin{array}{c}0.80 \\
(0.52)\end{array}$ \\
\hline GDP per capita $(\log )$ & & & $\begin{array}{l}0.83^{* *} \\
(0.40)\end{array}$ & $\begin{array}{l}0.79^{*} \\
(0.47)\end{array}$ \\
\hline GDP annual growth & & & $\begin{array}{c}0.03 \\
(0.07)\end{array}$ & $\begin{array}{l}-0.01 \\
(0.08)\end{array}$ \\
\hline Population Density ('000) & & & $\begin{array}{c}0.88 \\
(1.15)\end{array}$ & $\begin{array}{c}2.84 \\
(2.01)\end{array}$ \\
\hline $\begin{array}{l}\text { Population aged } 70 \text { or older } \\
\text { (percentage) }\end{array}$ & & & & $\begin{array}{c}-0.38^{* *} \\
(0.17)\end{array}$ \\
\hline Diabetes prevalence & & & & $\begin{array}{c}0.16 \\
(0.11)\end{array}$ \\
\hline Cardiovascular death rate & & & & $\begin{array}{c}0.01^{* *} \\
(0.003)\end{array}$ \\
\hline Constant & $\begin{array}{l}-0.04 \\
(0.34)\end{array}$ & $\begin{array}{l}-0.02 \\
(0.75)\end{array}$ & $\begin{array}{c}-7.90^{* *} \\
(3.94)\end{array}$ & $\begin{array}{l}-9.65^{* *} \\
(4.46)\end{array}$ \\
\hline Region FE & Yes & Yes & Yes & Yes \\
\hline Observations & 135 & 135 & 135 & 130 \\
\hline
\end{tabular}

${ }^{*} \mathrm{p}<0.1 ;{ }^{* *} \mathrm{p}<0.05 ;{ }^{* * *} \mathrm{p}<0.01$. Standard errors in parenthesis. Region-Fixed Effects include: Africa, Asia, Europe, North America, and South America. 15 
D.2 Re-evaluating Hypothesis 2 using the last semester of 2019 to measure violence against civilians 
Table D.2: Cox proportional hazards models of estimating the effect of recent state repression in the last three months of 2019 on the time to adopting a stay-at-home order

\begin{tabular}{|c|c|c|c|c|}
\hline & \multicolumn{4}{|c|}{ Days from first case to policy } \\
\hline & $(1)$ & $(2)$ & $(3)$ & $(4)$ \\
\hline $\begin{array}{l}\mathrm{N} \text { of violent events (log) } \\
\text { (per one million population) }\end{array}$ & $\begin{array}{c}0.56^{* * *} \\
(0.12)\end{array}$ & $\begin{array}{c}0.49^{* * *} \\
(0.13)\end{array}$ & $\begin{array}{c}0.57^{* * *} \\
(0.14)\end{array}$ & $\begin{array}{c}0.52^{* * *} \\
(0.15)\end{array}$ \\
\hline Democracy score (V-Dem) & & $\begin{array}{l}-0.22 \\
(0.59)\end{array}$ & $\begin{array}{c}0.15 \\
(0.62)\end{array}$ & $\begin{array}{c}0.92 \\
(0.72)\end{array}$ \\
\hline State Capacity & & $\begin{array}{l}-0.26 \\
(0.20)\end{array}$ & $\begin{array}{c}-0.72^{* * *} \\
(0.26)\end{array}$ & $\begin{array}{l}-0.42 \\
(0.29)\end{array}$ \\
\hline $\begin{array}{l}\text { Intrastate Armed Conflict } \\
\text { (Historical) }\end{array}$ & & $\begin{array}{l}-0.04 \\
(0.25)\end{array}$ & $\begin{array}{c}0.09 \\
(0.25)\end{array}$ & $\begin{array}{c}0.20 \\
(0.26)\end{array}$ \\
\hline GDP per capita (log) & & & $\begin{array}{c}0.49^{* * *} \\
(0.18)\end{array}$ & $\begin{array}{l}0.45^{* *} \\
(0.22)\end{array}$ \\
\hline GDP annual growth & & & $\begin{array}{c}0.03 \\
(0.04)\end{array}$ & $\begin{array}{l}-0.01 \\
(0.04)\end{array}$ \\
\hline Population Density ('000) & & & $\begin{array}{c}0.46 \\
(0.46)\end{array}$ & $\begin{array}{c}0.70 \\
(0.46)\end{array}$ \\
\hline $\begin{array}{l}\text { Population aged } 70 \text { or older } \\
\text { (percentage) }\end{array}$ & & & & $\begin{array}{l}-0.12 \\
(0.07)\end{array}$ \\
\hline Diabetes prevalence & & & & $\begin{array}{c}0.02 \\
(0.04)\end{array}$ \\
\hline Cardiovascular death rate & & & & $\begin{array}{l}0.002^{*} \\
(0.001)\end{array}$ \\
\hline Region FE & Yes & Yes & Yes & Yes \\
\hline $\mathrm{N}$ countries & 135 & 135 & 135 & 130 \\
\hline
\end{tabular}

${ }^{*} \mathrm{p}<0.1 ;{ }^{* *} \mathrm{p}<0.05 ;{ }^{* *} \mathrm{p}<0.01$. Positive coefficients in the Cox $\mathrm{PH}$ indicate that policies are expected to be adopted earlier. RegionFixed Effects include: Africa, Asia, Europe, North America, and South America. 
D.3 Re-evaluating Hypothesis 3 using the last semester of 2019 to measure violence against civilians 
Table D.3: OLS regressions on the effect of recent repression on the length of stay-at-home orders

\begin{tabular}{|c|c|c|c|c|}
\hline & \multicolumn{4}{|c|}{ Number of days with a policy $(\log )$} \\
\hline & $(1)$ & $(2)$ & $(3)$ & $(4)$ \\
\hline $\begin{array}{l}\mathrm{N} \text { of violent events }(\mathrm{log}) \\
\text { (per one million population) }\end{array}$ & $\begin{array}{c}0.69^{* * *} \\
(0.22)\end{array}$ & $\begin{array}{l}0.53^{* *} \\
(0.25)\end{array}$ & $\begin{array}{l}0.59^{* *} \\
(0.24)\end{array}$ & $\begin{array}{l}0.59^{* *} \\
(0.25)\end{array}$ \\
\hline Democracy score (V-Dem) & & $\begin{array}{l}-0.57 \\
(1.19)\end{array}$ & $\begin{array}{l}-0.06 \\
(1.25)\end{array}$ & $\begin{array}{l}1.06 \\
(1.23)\end{array}$ \\
\hline State capacity & & $\begin{array}{l}-0.22 \\
(0.31)\end{array}$ & $\begin{array}{l}-0.68 \\
(0.41)\end{array}$ & $\begin{array}{l}-0.17 \\
(0.40)\end{array}$ \\
\hline $\begin{array}{l}\text { Intrastate Armed Conflict } \\
\text { (Historical) }\end{array}$ & & $\begin{array}{c}0.34 \\
(0.41)\end{array}$ & $\begin{array}{c}0.42 \\
(0.43)\end{array}$ & $\begin{array}{c}0.57 \\
(0.43)\end{array}$ \\
\hline GDP per capita $(\log )$ & & & $\begin{array}{l}0.54^{*} \\
(0.31)\end{array}$ & $\begin{array}{c}0.48 \\
(0.37)\end{array}$ \\
\hline GDP annual growth & & & $\begin{array}{c}-0.0003 \\
(0.06)\end{array}$ & $\begin{array}{l}-0.03 \\
(0.06)\end{array}$ \\
\hline Population Density ('000) & & & $\begin{array}{c}0.33 \\
(0.71)\end{array}$ & $\begin{array}{c}0.75 \\
(1.21)\end{array}$ \\
\hline $\begin{array}{l}\text { Population aged } 70 \text { or older } \\
\text { (percentage) }\end{array}$ & & & & $\begin{array}{c}-0.24^{* * *} \\
(0.09)\end{array}$ \\
\hline Diabetes prevalence & & & & $\begin{array}{c}0.06 \\
(0.07)\end{array}$ \\
\hline Cardiovascular death rate & & & & $\begin{array}{c}0.003^{*} \\
(0.002)\end{array}$ \\
\hline Constant & $\begin{array}{c}2.18^{* * *} \\
(0.34)\end{array}$ & $\begin{array}{c}2.09^{* * *} \\
(0.74)\end{array}$ & $\begin{array}{l}-2.97 \\
(2.99)\end{array}$ & $\begin{array}{l}-3.33 \\
(3.44)\end{array}$ \\
\hline Region FE & Yes & Yes & Yes & Yes \\
\hline Observations & 135 & 135 & 135 & 130 \\
\hline
\end{tabular}

${ }^{*} \mathrm{p}<0.1 ;{ }^{* *} \mathrm{p}<0.05 ;{ }^{* * *} \mathrm{p}<0.01$. Robust standard errors in parenthesis. Region-Fixed Effects include: Africa, Asia, Europe, North America, and South Amertea. 


\section{E Robustness Checks to Using All Violence Against Civilians}

Our measure of Violence against Civilians from ACLED excludes violent events perpetrated by political organizations that aim at countering the established governing regimes (i.e., rebel groups), or violence that arises from civilians themselves (e.g., riots and protests). Given the methodological difficulties of accurately identifying the perpetrators of violence, we now evaluate whether these decisions affect our findings. To do this, in online Appendix E, we report the main findings using all Violence Against Civilians in the ACLED Dataset, i.e., removing any actor-related filters. When using All Violence Against Civilians as a measure of pre-outbreak domestic conflict, Tables E.1, E.2, and E.3 show that our main hypotheses remain substantively unaltered. 
E.1 Re-evaluating Hypothesis 1 Using All Violence Against Civilians 
Table E.1: Logistic regressions on the effect of recent state repression on adopting stay-athome orders

\begin{tabular}{|c|c|c|c|c|}
\hline & \multicolumn{4}{|c|}{ Adoption of a stay-at-home order } \\
\hline & $(1)$ & $(2)$ & $(3)$ & $(4)$ \\
\hline $\begin{array}{l}\mathrm{N} \text { of violent events }(\mathrm{log}) \\
\text { (per one million population) }\end{array}$ & $\begin{array}{l}0.53^{* *} \\
(0.21)\end{array}$ & $\begin{array}{l}0.44^{*} \\
(0.23)\end{array}$ & $\begin{array}{l}0.54^{* *} \\
(0.24)\end{array}$ & $\begin{array}{l}0.49^{*} \\
(0.26)\end{array}$ \\
\hline Democracy score (V-Dem) & & $\begin{array}{l}-0.73 \\
(1.12)\end{array}$ & $\begin{array}{l}-0.07 \\
(1.18)\end{array}$ & $\begin{array}{l}1.38 \\
(1.42)\end{array}$ \\
\hline State Capacity & & $\begin{array}{c}0.01 \\
(0.37)\end{array}$ & $\begin{array}{l}-0.70 \\
(0.52)\end{array}$ & $\begin{array}{c}0.12 \\
(0.59)\end{array}$ \\
\hline $\begin{array}{l}\text { Intrastate Armed Conflict } \\
\text { (Historical) }\end{array}$ & & $\begin{array}{c}0.47 \\
(0.45)\end{array}$ & $\begin{array}{c}0.61 \\
(0.47)\end{array}$ & $\begin{array}{l}0.87^{*} \\
(0.52)\end{array}$ \\
\hline GDP per capita (log) & & & $\begin{array}{l}0.80^{* *} \\
(0.40)\end{array}$ & $\begin{array}{c}0.63 \\
(0.45)\end{array}$ \\
\hline GDP Annual Growth & & & $\begin{array}{c}0.03 \\
(0.07)\end{array}$ & $\begin{array}{c}-0.001 \\
(0.08)\end{array}$ \\
\hline Population Density ('000) & & & $\begin{array}{c}0.84 \\
(1.16)\end{array}$ & $\begin{array}{c}1.90 \\
(1.69)\end{array}$ \\
\hline $\begin{array}{l}\text { Population aged } 70 \\
\text { or older (percentage) }\end{array}$ & & & & $\begin{array}{c}-0.31^{* *} \\
(0.14)\end{array}$ \\
\hline Diabetes prevalence & & & & $\begin{array}{l}0.20^{*} \\
(0.11)\end{array}$ \\
\hline Cardiovascular death rate & & & & $\begin{array}{c}0.01^{* *} \\
(0.003)\end{array}$ \\
\hline Constant & $\begin{array}{l}-0.15 \\
(0.37)\end{array}$ & $\begin{array}{l}-0.05 \\
(0.75)\end{array}$ & $\begin{array}{l}-7.61^{* *} \\
(3.87)\end{array}$ & $\begin{array}{c}-8.85^{* *} \\
(4.32)\end{array}$ \\
\hline Region FE & Yes & Yes & Yes & Yes \\
\hline Observations & 135 & 135 & 135 & 135 \\
\hline
\end{tabular}

${ }^{*} \mathrm{p}<0.1 ;{ }^{* *} \mathrm{p}<0.05 ;{ }^{* * *} \mathrm{p}<0.01$ andard errors in parenthesis. Region-Fixed Effects include: Africa, Asia, Europe, North America, and South America. 
E.2 Re-evaluating Hypothesis 2 Using All Violence Against Civilians 
Table E.2: Cox proportional hazards models of estimating the effect of state repression on the time to adopting a stay-at-home order

\begin{tabular}{|c|c|c|c|c|}
\hline & \multicolumn{4}{|c|}{ Days from 1st case to policy } \\
\hline & $(1)$ & (2) & (3) & $(4)$ \\
\hline $\begin{array}{l}\mathrm{N} \text { of violent events }(\mathrm{log}) \\
\text { (per one million population) }\end{array}$ & $\begin{array}{c}0.43^{* * *} \\
(0.10)\end{array}$ & $\begin{array}{c}0.39^{* * *} \\
(0.11)\end{array}$ & $\begin{array}{c}0.44^{* * *} \\
(0.11)\end{array}$ & $\begin{array}{c}0.42^{* * *} \\
(0.12)\end{array}$ \\
\hline Democracy score (V-Dem) & & $\begin{array}{l}-0.33 \\
(0.59)\end{array}$ & $\begin{array}{l}0.003 \\
(0.62)\end{array}$ & $\begin{array}{c}0.69 \\
(0.70)\end{array}$ \\
\hline State Capacity & & $\begin{array}{l}-0.21 \\
(0.20)\end{array}$ & $\begin{array}{c}-0.64^{* *} \\
(0.26)\end{array}$ & $\begin{array}{l}-0.43 \\
(0.28)\end{array}$ \\
\hline $\begin{array}{l}\text { Intrastate Armed Conflict } \\
\text { (Historical) }\end{array}$ & & $\begin{array}{l}-0.11 \\
(0.26)\end{array}$ & $\begin{array}{c}0.02 \\
(0.26)\end{array}$ & $\begin{array}{c}0.11 \\
(0.26)\end{array}$ \\
\hline GDP per capita (log) & & & $\begin{array}{l}0.46^{* *} \\
(0.19)\end{array}$ & $\begin{array}{l}0.41^{*} \\
(0.21)\end{array}$ \\
\hline GDP Annual Growth & & & $\begin{array}{c}0.04 \\
(0.04)\end{array}$ & $\begin{array}{c}0.01 \\
(0.04)\end{array}$ \\
\hline Population Density ('000) & & & $\begin{array}{c}0.49 \\
(0.45)\end{array}$ & $\begin{array}{c}0.62 \\
(0.46)\end{array}$ \\
\hline $\begin{array}{l}\text { Population aged } 70 \\
\text { or older (percentage) }\end{array}$ & & & & $\begin{array}{l}-0.10 \\
(0.06)\end{array}$ \\
\hline Diabetes prevalence & & & & $\begin{array}{c}0.04 \\
(0.04)\end{array}$ \\
\hline Cardiovascular death rate & & & & $\begin{array}{l}0.002^{*} \\
(0.001)\end{array}$ \\
\hline Region FE & Yes & Yes & Yes & Yes \\
\hline Observations & 135 & 135 & 135 & 135 \\
\hline
\end{tabular}

${ }^{*} \mathrm{p}<0.1 ;{ }^{* *} \mathrm{p}<0.05 ;{ }^{* * *} \mathrm{p}<0.01$. Standard errors in parenthesis. Region-Fixed Effects include: Africa, Asia, Europe, North America, and South America. 


\section{E.3 Re-evaluating Hypothesis 3 Using All Violence Against Civil- ians}


Table E.3: OLS regressions on the effect of repression on the length of stay-at-home orders

\begin{tabular}{|c|c|c|c|c|}
\hline & \multicolumn{4}{|c|}{ Number of days with policy $(\log )$} \\
\hline & $(1)$ & $(2)$ & $(3)$ & $(4)$ \\
\hline $\begin{array}{l}\mathrm{N} \text { of violent events (log) } \\
\text { (per one million population) }\end{array}$ & $\begin{array}{l}0.50^{* * *} \\
(0.15)\end{array}$ & $\begin{array}{l}0.38^{* *} \\
(0.18)\end{array}$ & $\begin{array}{l}0.43^{* *} \\
(0.17)\end{array}$ & $\begin{array}{l}0.39^{* *} \\
(0.17)\end{array}$ \\
\hline Democracy score (V-Dem) & & $\begin{array}{l}-0.61 \\
(1.19)\end{array}$ & $\begin{array}{l}-0.09 \\
(1.25)\end{array}$ & $\begin{array}{c}1.06 \\
(1.19)\end{array}$ \\
\hline State capacity & & $\begin{array}{l}-0.18 \\
(0.32)\end{array}$ & $\begin{array}{l}-0.63 \\
(0.42)\end{array}$ & $\begin{array}{l}-0.12 \\
(0.40)\end{array}$ \\
\hline $\begin{array}{l}\text { Intrastate Armed Conflict } \\
\text { (Historical) }\end{array}$ & & $\begin{array}{c}0.35 \\
(0.41)\end{array}$ & $\begin{array}{c}0.44 \\
(0.43)\end{array}$ & $\begin{array}{c}0.59 \\
(0.42)\end{array}$ \\
\hline GDP per capita (log) & & & $\begin{array}{l}0.56^{*} \\
(0.31)\end{array}$ & $\begin{array}{c}0.46 \\
(0.37)\end{array}$ \\
\hline GDP Annual Growth & & & $\begin{array}{l}0.003 \\
(0.06)\end{array}$ & $\begin{array}{l}-0.03 \\
(0.06)\end{array}$ \\
\hline Population Density ('000) & & & $\begin{array}{c}0.27 \\
(0.65)\end{array}$ & $\begin{array}{c}0.55 \\
(0.91)\end{array}$ \\
\hline $\begin{array}{l}\text { Population aged } 70 \text { or older } \\
\text { (percentage) }\end{array}$ & & & & $\begin{array}{c}-0.25^{* * *} \\
(0.08)\end{array}$ \\
\hline Diabetes prevalence & & & & $\begin{array}{c}0.07 \\
(0.07)\end{array}$ \\
\hline Cardiovascular death rate & & & & $\begin{array}{l}0.004^{*} \\
(0.002)\end{array}$ \\
\hline Constant & $\begin{array}{c}2.03^{* * *} \\
(0.36)\end{array}$ & $\begin{array}{c}2.01^{* * *} \\
(0.75)\end{array}$ & $\begin{array}{l}-3.19 \\
(3.01)\end{array}$ & $\begin{array}{l}-3.36 \\
(3.46)\end{array}$ \\
\hline Region FE & Yes & Yes & Yes & Yes \\
\hline Observations & 135 & 135 & 135 & 135 \\
\hline
\end{tabular}

${ }^{*} \mathrm{p}<0.1 ;{ }^{* *} \mathrm{p}<0.05 ;{ }^{* * *} \mathrm{p}<0.01$. R6bust standard errors in parenthesis. Region-Fixed Effects include: Africa, Asia, Europe, North America, and South America. 


\section{F Robustness Checks to Using a More Comprehensive Country Sample}

Whereas the models that use the latent human rights scores include nearly all world countries, the list of countries with available data in the ACLED in 2019 excludes significant world regions such as North America (United States and Canada), Western Europe (e.g., France, Germany, United Kingdom), and Oceania (e.g., Australia, New Zealand). The manner in which countries are missing from the data is not random: the excluded countries tend to have governments that, on average, use less violence against their citizens, are more democratic and developed, enjoy from greater state capacity, stronger medical infrastructure and, for these and many other reasons, they could have responded to the pandemic in a different way. Note that this missingness would impact our findings if these countries constitute a subset of world countries that have the least violence against civilians and, at the same time, reacted earlier to the pandemic, were more likely to adopt policies, and imposed policies for longer periods compared to countries in the ACLED sample.

While we do not have the resources to build a fine-grained data on political violence comparable to the ACLED for these out-of-sample countries, we evaluate the impact of their inclusion by assuming that all countries outside of the ACLED have had no record of state violence against citizens in 2019 - this is the most conservative value of state repression in these countries. We use the same data sources as described in the "Research Methods" section to build the rest of the dependent and control variables. Using this new dataset of up to 185 countries, the results reported in the online Appendix F show that the statistical reliability of the main coefficients remain substantively unaltered. Overall, this evidence suggests that the convenience sample provided by ACLED is unlikely to drive the main findings.

Using the same ACLED sample as described in the main text, we assign 0 to all the countries with a missing value in the measure of the number of ACLED events involving 
violence against civilians. We now proceed to evaluate the robustness of our three main hypotheses to the inclusion of these countries in the ACLED Models:

- For a re-evaluation of Hypothesis 1, see Appendix F.1.

- For a re-evaluation of Hypothesis 2, see Appendix F.2.

- For a re-evaluation of Hypothesis 3, see Appendix F.3. 
F.1 Re-evaluating Hypothesis 1 with an expanded country sample 
Table F.1: Logistic regressions on the effect of recent state repression on adopting stay-athome orders (expanded sample)

\begin{tabular}{|c|c|c|c|c|}
\hline & \multicolumn{4}{|c|}{ Adoption of a stay-at-home order } \\
\hline & $(1)$ & $(2)$ & $(3)$ & $(4)$ \\
\hline $\begin{array}{l}\mathrm{N} \text { of violent events }(\log ) \\
\text { (per one million population) }\end{array}$ & $\begin{array}{l}0.71^{* * *} \\
(0.22)\end{array}$ & $\begin{array}{l}0.49^{* *} \\
(0.24)\end{array}$ & $\begin{array}{l}0.57^{* *} \\
(0.26)\end{array}$ & $\begin{array}{c}0.46^{*} \\
(0.27)\end{array}$ \\
\hline Democracy score (V-Dem) & & $\begin{array}{l}-0.54 \\
(0.99)\end{array}$ & $\begin{array}{c}0.25 \\
(1.05)\end{array}$ & $\begin{array}{c}1.74 \\
(1.23)\end{array}$ \\
\hline State Capacity & & $\begin{array}{l}-0.10 \\
(0.29)\end{array}$ & $\begin{array}{l}-0.75^{*} \\
(0.41)\end{array}$ & $\begin{array}{l}-0.34 \\
(0.45)\end{array}$ \\
\hline $\begin{array}{l}\text { Intrastate Armed Conflict } \\
\text { (Historical) }\end{array}$ & & $\begin{array}{l}0.66^{*} \\
(0.40)\end{array}$ & $\begin{array}{l}0.84^{* *} \\
(0.41)\end{array}$ & $\begin{array}{l}1.01^{* *} \\
(0.44)\end{array}$ \\
\hline GDP per capita (log) & & & $\begin{array}{l}0.66^{*} \\
(0.34)\end{array}$ & $\begin{array}{c}0.34 \\
(0.38)\end{array}$ \\
\hline GDP Annual Growth & & & $\begin{array}{l}-0.02 \\
(0.06)\end{array}$ & $\begin{array}{l}-0.05 \\
(0.07)\end{array}$ \\
\hline Population Density ('000) & & & $\begin{array}{c}0.41 \\
(0.44)\end{array}$ & $\begin{array}{c}0.38 \\
(0.42)\end{array}$ \\
\hline $\begin{array}{l}\text { Population aged } 70 \\
\text { or older (percentage) }\end{array}$ & & & & $\begin{array}{l}-0.08 \\
(0.10)\end{array}$ \\
\hline Diabetes prevalence & & & & $\begin{array}{c}0.23^{* * *} \\
(0.08)\end{array}$ \\
\hline Cardiovascular death rate & & & & $\begin{array}{c}0.004 \\
(0.002)\end{array}$ \\
\hline Constant & $\begin{array}{l}-0.11 \\
(0.33)\end{array}$ & $\begin{array}{l}-0.18 \\
(0.66)\end{array}$ & $\begin{array}{r}-6.46^{*} \\
(3.33)\end{array}$ & $\begin{array}{c}-6.14^{*} \\
(3.62)\end{array}$ \\
\hline Region FE & Yes & Yes & Yes & Yes \\
\hline Observations & $\frac{185}{30}$ & 181 & 181 & 179 \\
\hline
\end{tabular}

${ }^{*} \mathrm{p}<0.1 ;{ }^{* *} \mathrm{p}<0.05 ;{ }^{* * *} \mathrm{p}<0.01$. Standard errors in parenthesis. Region-Fixed Effects include: Africa, Asia, Europe, North Amer- 
F.2 Re-evaluating Hypothesis 2 with an expanded country sample 
Table F.2: Cox proportional hazards models of estimating the effect of state repression on the time to adopting a stay-at-home order (expanded sample)

\begin{tabular}{|c|c|c|c|c|}
\hline & \multicolumn{4}{|c|}{ Days from 1st case to policy } \\
\hline & $(1)$ & $(2)$ & $(3)$ & $(4)$ \\
\hline $\begin{array}{l}\mathrm{N} \text { of violent events (log) } \\
\text { (per one million population) }\end{array}$ & $\begin{array}{c}0.49^{* * *} \\
(0.09)\end{array}$ & $\begin{array}{c}0.37^{* * *} \\
(0.11)\end{array}$ & $\begin{array}{c}0.42^{* * *} \\
(0.12)\end{array}$ & $\begin{array}{c}0.38^{* * *} \\
(0.12)\end{array}$ \\
\hline Democracy score (V-Dem) & & $\begin{array}{l}-0.19 \\
(0.54)\end{array}$ & $\begin{array}{c}0.16 \\
(0.58)\end{array}$ & $\begin{array}{c}0.82 \\
(0.65)\end{array}$ \\
\hline State Capacity & & $\begin{array}{l}-0.27 \\
(0.16)\end{array}$ & $\begin{array}{c}-0.63^{* * *} \\
(0.21)\end{array}$ & $\begin{array}{c}-0.47^{* *} \\
(0.23)\end{array}$ \\
\hline $\begin{array}{l}\text { Intrastate Armed Conflict } \\
\text { (Historical) }\end{array}$ & & $\begin{array}{c}0.08 \\
(0.23)\end{array}$ & $\begin{array}{c}0.20 \\
(0.23)\end{array}$ & $\begin{array}{c}0.28 \\
(0.23)\end{array}$ \\
\hline GDP per capita (log) & & & $\begin{array}{l}0.40^{* *} \\
(0.16)\end{array}$ & $\begin{array}{c}0.30 \\
(0.19)\end{array}$ \\
\hline GDP Annual Growth & & & $\begin{array}{c}0.01 \\
(0.03)\end{array}$ & $\begin{array}{c}0.0004 \\
(0.03)\end{array}$ \\
\hline Population Density ('000) & & & $\begin{array}{c}0.16 \\
(0.14)\end{array}$ & $\begin{array}{c}0.16 \\
(0.14)\end{array}$ \\
\hline $\begin{array}{l}\text { Population aged } 70 \\
\text { or older (percentage) }\end{array}$ & & & & $\begin{array}{l}-0.02 \\
(0.05)\end{array}$ \\
\hline Diabetes prevalence & & & & $\begin{array}{l}0.08^{* *} \\
(0.03)\end{array}$ \\
\hline Cardiovascular death rate & & & & $\begin{array}{c}0.001 \\
(0.001)\end{array}$ \\
\hline Region FE & Yes & Yes & Yes & Yes \\
\hline Observations & 185 & 181 & 181 & 179 \\
\hline
\end{tabular}

${ }^{*} \mathrm{p}<0.1 ;{ }^{* *} \mathrm{p}<0.05 ;{ }^{* * *} \mathrm{p}<0.01$. Standard errors in parenthesis. Region-Fixed Effects include: Africa, Asia, Europe, North America, South America, and Oceania. 
F.3 Re-evaluating Hypothesis 3 with an expanded country sample 
Table F.3: OLS regressions on the effect of repression on the length of stay-at-home orders (expanded sample)

\begin{tabular}{|c|c|c|c|c|}
\hline & \multicolumn{4}{|c|}{ Number of days with policy (log) } \\
\hline & (1) & $(2)$ & $(3)$ & (4) \\
\hline $\begin{array}{l}\mathrm{N} \text { of violent events (log) } \\
\text { (per one million population) }\end{array}$ & $\begin{array}{c}0.67^{* * *} \\
(0.18)\end{array}$ & $\begin{array}{l}0.43^{* *} \\
(0.20)\end{array}$ & $\begin{array}{l}0.44^{* *} \\
(0.19)\end{array}$ & $\begin{array}{l}0.39^{* *} \\
(0.18)\end{array}$ \\
\hline Democracy score (V-Dem) & & $\begin{array}{l}-0.61 \\
(1.19)\end{array}$ & $\begin{array}{c}0.02 \\
(1.08)\end{array}$ & $\begin{array}{c}1.07 \\
(1.07)\end{array}$ \\
\hline State capacity & & $\begin{array}{l}-0.20 \\
(0.31)\end{array}$ & $\begin{array}{c}-0.67^{*} \\
(0.36)\end{array}$ & $\begin{array}{l}-0.28 \\
(0.37)\end{array}$ \\
\hline $\begin{array}{l}\text { Intrastate Armed Conflict } \\
\text { (Historical) }\end{array}$ & & $\begin{array}{c}0.65 \\
(0.41)\end{array}$ & $\begin{array}{l}0.75^{* *} \\
(0.37)\end{array}$ & $\begin{array}{l}0.91^{* *} \\
(0.37)\end{array}$ \\
\hline GDP per capita (log) & & & $\begin{array}{c}0.45 \\
(0.29)\end{array}$ & $\begin{array}{c}0.30 \\
(0.32)\end{array}$ \\
\hline GDP Annual Growth & & & $\begin{array}{l}-0.03 \\
(0.05)\end{array}$ & $\begin{array}{l}-0.06 \\
(0.05)\end{array}$ \\
\hline Population Density ('000) & & & $\begin{array}{c}0.32 \\
(0.29)\end{array}$ & $\begin{array}{c}0.31 \\
(0.38)\end{array}$ \\
\hline $\begin{array}{l}\text { Population aged } 70 \text { or older } \\
\text { (percentage) }\end{array}$ & & & & $\begin{array}{r}-0.13^{*} \\
(0.07)\end{array}$ \\
\hline Diabetes prevalence & & & & $\begin{array}{l}0.11^{* *} \\
(0.05)\end{array}$ \\
\hline Cardiovascular death rate & & & & $\begin{array}{c}0.002 \\
(0.002)\end{array}$ \\
\hline Constant & $\begin{array}{c}2.01^{* * *} \\
(0.35)\end{array}$ & $\begin{array}{l}1.91^{* *} \\
(0.74)\end{array}$ & $\begin{array}{l}-2.37 \\
(2.79)\end{array}$ & $\begin{array}{l}-2.23 \\
(3.11)\end{array}$ \\
\hline Region FE & Yes & Yes & Yes & Yes \\
\hline Observations & 185 & 181 & 181 & 179 \\
\hline
\end{tabular}

${ }^{*} \mathrm{p}<0.1 ;{ }^{* *} \mathrm{p}<0.05 ;{ }^{* * *} \mathrm{p}<0.01$. Rgpust standard errors in parenthesis. Region-Fixed Effects include: Africa, Asia, Europe, North America, and South America. 


\section{G Robustness to Adding an Alternative Measure of State Capacity}

Across all models, we control for state capacity to control for variation in the capacity of states to credibly formulate and implement policies such as stay-at-home orders as well as repressive policies.

While there are a number of indicators of state capacity in the literature, we have chosen the Government Effectiveness from the World Bank Indicators (WBI) for two reasons: 1) Conceptual clarity of the government effectiveness indicator as it specifically measures "the quality of public services, the quality of the civil service and the degree of its independence from political pressures, the quality of policy formulation and implementation, and the credibility of the government's commitment to such policies;" and, 2) Extensive coverage $(\mathrm{N}=$ 193 countries), which means a greater coverage than any other state capacity indicator in the literature (the closest in coverage is the Corruption Perceptions Index (CPI) with 180 countries). With this said, Vaccaro (2020) reports a high correlation $(>0.8)$ with all other available indicators of state capacity. For a review on state capacity indicators, see Vaccaro (2020).

Another indicator from the WBI labeled as 'The Rule of Law' could also capture this concept. The WBI defines it as a measure that "Reflects perceptions of the extent to which agents have confidence in and abide by the rules of society, and in particular the quality of contract enforcement, property rights, the police, and the courts, as well as the likelihood of crime and violence." The correlation between the two indicators: 'the Government Effectiveness' and the 'Rule of Law' is 0.93. Despite the high correlation, we ensure the robustness of our findings to alternative conceptions of state capacity by reestimating our models with this alternative control in this Online Appendix:

- For a re-evaluation of Hypothesis 1, see Appendix G.1.

- For a re-evaluation of Hypothesis 2, see Appendix G.2. 
- For a re-evaluation of Hypothesis 3, see Appendix G.3. 


\section{G.1 Re-evaluating Hypothesis 1 with an alternative indicator of state capacity}

Table G.1: Logistic regressions on the effect of recent state repression on adopting stay-athome orders (alternative indicator of state capacity)

\begin{tabular}{|c|c|c|c|c|c|c|c|c|}
\hline & \multicolumn{8}{|c|}{ Adoption of a stay-at-home order } \\
\hline & $(1)$ & $(2)$ & $(3)$ & $(4)$ & (5) & $(6)$ & $(7)$ & $(8)$ \\
\hline $\begin{array}{l}\mathrm{N} \text { of violent events }(\mathrm{log}) \\
\text { (per one million population) }\end{array}$ & $\begin{array}{r}0.66^{* * *} \\
(0.24)\end{array}$ & $\begin{array}{l}0.64^{* *} \\
(0.27)\end{array}$ & $\begin{array}{l}0.72^{* *} \\
(0.28)\end{array}$ & $\begin{array}{l}0.67^{* *} \\
(0.31)\end{array}$ & & & & \\
\hline Human Rights Protection Score & & & & & $\begin{array}{c}-0.55^{* * *} \\
(0.14)\end{array}$ & $\begin{array}{c}-0.64^{* * *} \\
(0.21)\end{array}$ & $\begin{array}{l}-0.68^{* * *} \\
(0.21)\end{array}$ & $\begin{array}{c}-0.76^{* * *} \\
(0.24)\end{array}$ \\
\hline Democracy score (V-Dem) & & $\begin{array}{l}-1.10 \\
(1.19)\end{array}$ & $\begin{array}{l}-0.45 \\
(1.26)\end{array}$ & $\begin{array}{c}0.95 \\
(1.57)\end{array}$ & & $\begin{array}{c}0.38 \\
(1.12)\end{array}$ & $\begin{array}{l}1.27 \\
(1.21)\end{array}$ & $\begin{array}{l}3.09^{* *} \\
(1.42)\end{array}$ \\
\hline Rule of Law & & $\begin{array}{c}0.28 \\
(0.42)\end{array}$ & $\begin{array}{l}-0.27 \\
(0.53)\end{array}$ & $\begin{array}{c}0.41 \\
(0.62)\end{array}$ & & $\begin{array}{c}0.18 \\
(0.32)\end{array}$ & $\begin{array}{l}-0.29 \\
(0.41)\end{array}$ & $\begin{array}{c}0.31 \\
(0.47)\end{array}$ \\
\hline $\begin{array}{l}\text { Intrastate Armed Conflict } \\
\text { (Historical) }\end{array}$ & & $\begin{array}{c}0.54 \\
(0.46)\end{array}$ & $\begin{array}{c}0.64 \\
(0.47)\end{array}$ & $\begin{array}{l}0.94^{*} \\
(0.52)\end{array}$ & & $\begin{array}{c}0.44 \\
(0.42)\end{array}$ & $\begin{array}{c}0.54 \\
(0.44)\end{array}$ & $\begin{array}{c}0.74 \\
(0.47)\end{array}$ \\
\hline GDP per capita $(\log )$ & & & $\begin{array}{l}0.59^{*} \\
(0.35)\end{array}$ & $\begin{array}{c}0.64 \\
(0.41)\end{array}$ & & & $\begin{array}{c}0.42 \\
(0.30)\end{array}$ & $\begin{array}{c}0.23 \\
(0.33)\end{array}$ \\
\hline GDP Annual Growth & & & $\begin{array}{c}0.01 \\
(0.07)\end{array}$ & $\begin{array}{c}-0.003 \\
(0.08)\end{array}$ & & & $\begin{array}{l}-0.06 \\
(0.06)\end{array}$ & $\begin{array}{l}-0.08 \\
(0.07)\end{array}$ \\
\hline Population Density ('000) & & & $\begin{array}{c}0.81 \\
(1.12)\end{array}$ & $\begin{array}{c}1.87 \\
(1.69)\end{array}$ & & & $\begin{array}{c}0.34 \\
(0.41)\end{array}$ & $\begin{array}{c}0.32 \\
(0.39)\end{array}$ \\
\hline $\begin{array}{l}\text { Population aged } 70 \\
\text { or older (percentage) }\end{array}$ & & & & $\begin{array}{c}-0.33^{* *} \\
(0.14)\end{array}$ & & & & $\begin{array}{l}-0.16 \\
(0.10)\end{array}$ \\
\hline Diabetes prevalence & & & & $\begin{array}{l}0.18^{*} \\
(0.11)\end{array}$ & & & & $\begin{array}{c}0.26^{* * *} \\
(0.09)\end{array}$ \\
\hline Cardiovascular death rate & & & & $\begin{array}{c}0.01^{* *} \\
(0.003)\end{array}$ & & & & $\begin{array}{c}0.01^{* *} \\
(0.002)\end{array}$ \\
\hline Constant & $\begin{array}{l}-0.17 \\
(0.36)\end{array}$ & $\begin{array}{c}0.15 \\
(0.77)\end{array}$ & $\begin{array}{l}-5.46 \\
(3.45)\end{array}$ & $\begin{array}{c}-8.66^{* *} \\
(3.98)\end{array}$ & $\begin{array}{c}0.42 \\
(0.30)\end{array}$ & $\begin{array}{c}0.12 \\
(0.70)\end{array}$ & $\begin{array}{l}-3.88 \\
(2.86)\end{array}$ & $\begin{array}{l}-5.20 \\
(3.19)\end{array}$ \\
\hline Region FE & Yes & Yes & Yes & Yes & Yes & Yes & Yes & Yes \\
\hline Observations & 135 & 135 & 135 & 135 & 182 & 180 & 180 & 178 \\
\hline
\end{tabular}

${ }^{*} \mathrm{p}<0.1 ;{ }^{* *} \mathrm{p}<0.05 ;{ }^{* * *} \mathrm{p}<0.01$. Standard errors in parenthesis. Region-Fixed Effects include:

Africa, Asia, Europe, North America, South America, and Oceania. 


\section{G.2 Re-evaluating Hypothesis 2 with an alternative indicator of state capacity}

Table G.2: Cox proportional hazards models of estimating the effect of state repression on the time to adopting a stay-at-home order (alternative indicator of state capacity)

\begin{tabular}{|c|c|c|c|c|c|c|c|c|}
\hline & \multicolumn{8}{|c|}{ Number of days since the first COVID-19 case to policy } \\
\hline & $(1)$ & $(2)$ & $(3)$ & $(4)$ & $(5)$ & (6) & (7) & $(8)$ \\
\hline $\begin{array}{l}\mathrm{N} \text { of violent events (log) } \\
\text { (per one million population) }\end{array}$ & $\begin{array}{c}0.48^{* * *} \\
(0.10)\end{array}$ & $\begin{array}{c}0.46^{* * *} \\
(0.12)\end{array}$ & $\begin{array}{c}0.48^{* * *} \\
(0.12)\end{array}$ & $\begin{array}{c}0.45^{* * *} \\
(0.13)\end{array}$ & & & & \\
\hline Human Rights Protection Score & & & & & $\begin{array}{c}-0.32^{* * *} \\
(0.07)\end{array}$ & $\begin{array}{c}-0.32^{* * *} \\
(0.11)\end{array}$ & $\begin{array}{c}-0.32^{* * *} \\
(0.11)\end{array}$ & $\begin{array}{c}-0.29^{* * *} \\
(0.11)\end{array}$ \\
\hline Democracy score (V-Dem) & & $\begin{array}{l}-0.53 \\
(0.62)\end{array}$ & $\begin{array}{l}-0.21 \\
(0.66)\end{array}$ & $\begin{array}{c}0.54 \\
(0.76)\end{array}$ & & $\begin{array}{c}0.39 \\
(0.60)\end{array}$ & $\begin{array}{c}0.76 \\
(0.64)\end{array}$ & $\begin{array}{l}1.46^{* *} \\
(0.70)\end{array}$ \\
\hline Rule of Law & & $\begin{array}{l}-0.03 \\
(0.22)\end{array}$ & $\begin{array}{l}-0.32 \\
(0.28)\end{array}$ & $\begin{array}{l}-0.11 \\
(0.32)\end{array}$ & & $\begin{array}{l}-0.15 \\
(0.17)\end{array}$ & $\begin{array}{l}-0.32 \\
(0.22)\end{array}$ & $\begin{array}{l}-0.21 \\
(0.25)\end{array}$ \\
\hline $\begin{array}{l}\text { Intrastate Armed Conflict } \\
\text { (Historical) }\end{array}$ & & $\begin{array}{l}-0.04 \\
(0.26)\end{array}$ & $\begin{array}{c}0.03 \\
(0.26)\end{array}$ & $\begin{array}{c}0.13 \\
(0.26)\end{array}$ & & $\begin{array}{c}0.03 \\
(0.24)\end{array}$ & $\begin{array}{c}0.08 \\
(0.24)\end{array}$ & $\begin{array}{c}0.14 \\
(0.25)\end{array}$ \\
\hline GDP per capita $(\log )$ & & & $\begin{array}{c}0.30^{*} \\
(0.18)\end{array}$ & $\begin{array}{c}0.26 \\
(0.20)\end{array}$ & & & $\begin{array}{c}0.16 \\
(0.16)\end{array}$ & $\begin{array}{c}0.05 \\
(0.18)\end{array}$ \\
\hline GDP Annual Growth & & & $\begin{array}{c}0.02 \\
(0.04)\end{array}$ & $\begin{array}{l}-0.01 \\
(0.04)\end{array}$ & & & $\begin{array}{l}-0.03 \\
(0.03)\end{array}$ & $\begin{array}{l}-0.03 \\
(0.03)\end{array}$ \\
\hline Population Density ('000) & & & $\begin{array}{c}0.36 \\
(0.50)\end{array}$ & $\begin{array}{c}0.53 \\
(0.48)\end{array}$ & & & $\begin{array}{c}0.15 \\
(0.13)\end{array}$ & $\begin{array}{c}0.14 \\
(0.14)\end{array}$ \\
\hline $\begin{array}{l}\text { Population aged } 70 \\
\text { or older (percentage) }\end{array}$ & & & & $\begin{array}{c}-0.12^{*} \\
(0.06)\end{array}$ & & & & $\begin{array}{l}-0.04 \\
(0.05)\end{array}$ \\
\hline Diabetes prevalence & & & & $\begin{array}{c}0.04 \\
(0.04)\end{array}$ & & & & $\begin{array}{c}0.10^{* * *} \\
(0.03)\end{array}$ \\
\hline Cardiovascular death rate & & & & $\begin{array}{l}0.002^{* *} \\
(0.001)\end{array}$ & & & & $\begin{array}{c}0.001 \\
(0.001)\end{array}$ \\
\hline Regi & Yes & Yes & Yes & Yes & Yes & Yes & Yes & Yes \\
\hline Observations & 135 & 135 & 135 & 135 & 182 & 180 & 180 & 178 \\
\hline
\end{tabular}

${ }^{*} \mathrm{p}<0.1 ;{ }^{* *} \mathrm{p}<0.05 ;{ }^{* * *} \mathrm{p}<0.01$. Standard errors in parenthesis. Region-Fixed Effects include:

Africa, Asia, Europe, North America, South America, and Oceania. 


\section{G.3 Re-evaluating Hypothesis 3 with an alternative indicator of state capacity}

Table G.3: OLS regressions on the effect of repression on the length of stay-at-home orders (alternative indicator of state capacity)

\begin{tabular}{|c|c|c|c|c|c|c|c|c|}
\hline & \multicolumn{8}{|c|}{ Number of days with stay-at-home order $(\log )$} \\
\hline & (1) & $(2)$ & (3) & $(4)$ & (5) & (6) & (7) & (8) \\
\hline $\begin{array}{l}\mathrm{N} \text { of violent events }(\mathrm{log}) \\
\text { (per one million population) }\end{array}$ & $\begin{array}{r}0.59^{* * *} \\
(0.18)\end{array}$ & $\begin{array}{l}0.53^{* *} \\
(0.21)\end{array}$ & $\begin{array}{c}0.55^{* * *} \\
(0.21)\end{array}$ & $\begin{array}{l}0.50^{* *} \\
(0.20)\end{array}$ & & & & \\
\hline Human Rights Protection Score & & & & & $\begin{array}{l}-0.41^{* * *} \\
(0.09)\end{array}$ & $\begin{array}{l}-0.53^{* * *} \\
(0.15)\end{array}$ & $\begin{array}{c}-0.58^{* * *} \\
(0.15)\end{array}$ & $\begin{array}{l}-0.52^{* * *} \\
(0.15)\end{array}$ \\
\hline Democracy score (V-Dem) & & $\begin{array}{l}-0.94 \\
(1.23)\end{array}$ & $\begin{array}{l}-0.50 \\
(1.30)\end{array}$ & $\begin{array}{c}0.72 \\
(1.26)\end{array}$ & & $\begin{array}{c}1.11 \\
(0.88)\end{array}$ & $\begin{array}{l}1.78^{* *} \\
(0.90)\end{array}$ & $\begin{array}{l}2.63^{* * *} \\
(1.00)\end{array}$ \\
\hline Rule of Law & & $\begin{array}{c}0.06 \\
(0.37)\end{array}$ & $\begin{array}{l}-0.24 \\
(0.46)\end{array}$ & $\begin{array}{c}0.15 \\
(0.44)\end{array}$ & & & & \\
\hline $\begin{array}{l}\text { Intrastate Armed Conflict } \\
\text { (Historical) }\end{array}$ & & $\begin{array}{c}0.41 \\
(0.42)\end{array}$ & $\begin{array}{c}0.46 \\
(0.44)\end{array}$ & $\begin{array}{c}0.64 \\
(0.43)\end{array}$ & & $\begin{array}{c}0.38 \\
(0.38)\end{array}$ & $\begin{array}{c}0.48 \\
(0.37)\end{array}$ & $\begin{array}{c}0.59 \\
(0.37)\end{array}$ \\
\hline GDP per capita $(\log )$ & & & $\begin{array}{c}0.36 \\
(0.29)\end{array}$ & $\begin{array}{c}0.39 \\
(0.33)\end{array}$ & & & $\begin{array}{l}0.62^{* * *} \\
(0.24)\end{array}$ & $\begin{array}{c}0.42 \\
(0.28)\end{array}$ \\
\hline GDP Annual Growth & & & $\begin{array}{l}-0.02 \\
(0.06)\end{array}$ & $\begin{array}{l}-0.04 \\
(0.06)\end{array}$ & & & $\begin{array}{l}-0.05 \\
(0.05)\end{array}$ & $\begin{array}{l}-0.08 \\
(0.05)\end{array}$ \\
\hline Population Density ('000) & & & $\begin{array}{c}0.28 \\
(0.70)\end{array}$ & $\begin{array}{c}0.53 \\
(0.94)\end{array}$ & & & $\begin{array}{c}0.28 \\
(0.44)\end{array}$ & $\begin{array}{c}0.25 \\
(0.55)\end{array}$ \\
\hline $\begin{array}{l}\text { Population aged } 70 \\
\text { or older (percentage) }\end{array}$ & & & & $\begin{array}{l}-0.26^{* * *} \\
(0.08)\end{array}$ & & & & $\begin{array}{l}-0.05 \\
(0.05)\end{array}$ \\
\hline Diabetes prevalence & & & & $\begin{array}{c}0.06 \\
(0.07)\end{array}$ & & & & $\begin{array}{l}0.11^{* *} \\
(0.05)\end{array}$ \\
\hline Cardiovascular death rate & & & & $\begin{array}{l}0.004^{* *} \\
(0.002)\end{array}$ & & & & $\begin{array}{l}0.003^{*} \\
(0.002)\end{array}$ \\
\hline Constant & $\begin{array}{c}2.03^{* * *} \\
(0.35)\end{array}$ & $\begin{array}{c}2.24^{* * *} \\
(0.74)\end{array}$ & $\begin{array}{l}-1.09 \\
(2.82)\end{array}$ & $\begin{array}{l}-2.48 \\
(3.10)\end{array}$ & $\begin{array}{c}3.20^{* * *} \\
(0.17)\end{array}$ & $\begin{array}{c}2.48^{* * *} \\
(0.53)\end{array}$ & $\begin{array}{l}-3.56 \\
(2.42)\end{array}$ & $\begin{array}{l}-3.53 \\
(2.75)\end{array}$ \\
\hline Region FE & Yes & Yes & Yes & Yes & Yes & Yes & Yes & Yes \\
\hline Observations & 135 & 135 & 135 & 135 & 182 & 180 & 180 & 178 \\
\hline
\end{tabular}

${ }^{*} \mathrm{p}<0.1 ;{ }^{* *} \mathrm{p}<0.05 ;{ }^{* * *} \mathrm{p}<0.01$. Standard errors in parenthesis. Region-Fixed Effects include:

Africa, Asia, Europe, North America, South America, and Oceania. 


\section{H Robustness to Police and Military Personnel}

An argument could be made that abusive states could have greater resources, could be more capable of and more ready for using force within its own borders to restrict people's freedom of movement. While we cannot directly measure a country's capacity to enforce a stay-athome order, we could capture capability of restricting internal freedoms of movements by measuring (a) the number of military personnel in active, regular military units of the land, naval, and air components; and, (b) the best estimate of the number of police officers per 100 inhabitants. As imperfect as these measures might be, we expect them to be positively correlated with a country's capacity to enforce a stay-at-home order. Our results indicate that adding these "capacity to enforce" controls do not affect our main explanatory variables. This suggests that the drivers of our association is more likely to be governments' willingness rather than governments' capacity to enforce restrictions. 


\section{H.1 Re-evaluating Hypothesis 1 after controlling for army and police personnel}

Table H.1: Logistic regressions on the effect of recent state repression on adopting stay-athome orders

\begin{tabular}{|c|c|c|c|c|}
\hline & \multicolumn{4}{|c|}{ Adoption of a stay-at-home order } \\
\hline & $(1)$ & $(2)$ & $(3)$ & $(4)$ \\
\hline $\begin{array}{l}\mathrm{N} \text { of violent events }(\log ) \\
\text { (per one million population) }\end{array}$ & $\begin{array}{l}0.62^{*} \\
(0.33)\end{array}$ & $\begin{array}{l}1.01^{*} \\
(0.58)\end{array}$ & & \\
\hline Human Rights Protection Score & & & $\begin{array}{c}-0.91^{* * *} \\
(0.26)\end{array}$ & $\begin{array}{c}-0.75^{* * *} \\
(0.28)\end{array}$ \\
\hline Armed combat personal (\%) & $\begin{array}{c}0.20 \\
(0.62)\end{array}$ & & $\begin{array}{c}0.17 \\
(0.51)\end{array}$ & \\
\hline $\begin{array}{l}\text { Number of police officers } \\
\text { (per } 100,000 \text { people) }\end{array}$ & & $\begin{array}{c}0.001 \\
(0.002)\end{array}$ & & $\begin{array}{l}-0.001 \\
(0.002)\end{array}$ \\
\hline Democracy score (V-Dem) & $\begin{array}{c}1.18 \\
(1.46)\end{array}$ & $\begin{array}{l}1.16 \\
(2.55)\end{array}$ & $\begin{array}{l}3.31^{* *} \\
(1.45)\end{array}$ & $\begin{array}{l}4.12^{*} \\
(2.12)\end{array}$ \\
\hline State Capacity & $\begin{array}{c}0.07 \\
(0.62)\end{array}$ & $\begin{array}{l}-0.60 \\
(1.29)\end{array}$ & $\begin{array}{l}-0.32 \\
(0.51)\end{array}$ & $\begin{array}{l}-1.57^{*} \\
(0.90)\end{array}$ \\
\hline $\begin{array}{l}\text { Intrastate Armed Conflict } \\
\text { (Historical) }\end{array}$ & $\begin{array}{l}0.88^{*} \\
(0.52)\end{array}$ & $\begin{array}{l}1.45 \\
(0.97)\end{array}$ & $\begin{array}{c}0.66 \\
(0.49)\end{array}$ & $\begin{array}{c}0.94 \\
(0.74)\end{array}$ \\
\hline GDP per capita (log) & $\begin{array}{c}0.69 \\
(0.48)\end{array}$ & $\begin{array}{c}1.27 \\
(0.90)\end{array}$ & $\begin{array}{c}0.66 \\
(0.42)\end{array}$ & $\begin{array}{c}0.73 \\
(0.70)\end{array}$ \\
\hline GDP Annual Growth & $\begin{array}{c}0.02 \\
(0.08)\end{array}$ & $\begin{array}{c}-0.004 \\
(0.13)\end{array}$ & $\begin{array}{l}-0.03 \\
(0.07)\end{array}$ & $\begin{array}{l}-0.06 \\
(0.11)\end{array}$ \\
\hline Population density & $\begin{array}{c}0.003 \\
(0.002)\end{array}$ & $\begin{array}{c}0.01 \\
(0.003)\end{array}$ & $\begin{array}{c}0.001 \\
(0.001)\end{array}$ & $\begin{array}{c}0.001 \\
(0.0005)\end{array}$ \\
\hline $\begin{array}{l}\text { Population aged } 70 \\
\text { (or older) }\end{array}$ & $\begin{array}{c}-0.28^{*} \\
(0.14)\end{array}$ & $\begin{array}{c}-0.73^{* * *} \\
(0.27)\end{array}$ & $\begin{array}{l}-0.08 \\
(0.11)\end{array}$ & $\begin{array}{l}-0.22 \\
(0.14)\end{array}$ \\
\hline Diabetes prevalence & $\begin{array}{c}0.20^{*} \\
(0.11)\end{array}$ & $\begin{array}{l}0.45^{* *} \\
(0.22)\end{array}$ & $\begin{array}{l}0.22^{* *} \\
(0.09)\end{array}$ & $\begin{array}{l}0.37^{* *} \\
(0.15)\end{array}$ \\
\hline Cardiovascular death rate & $\begin{array}{c}0.01^{* *} \\
(0.003)\end{array}$ & $\begin{array}{c}0.01 \\
(0.01)\end{array}$ & $\begin{array}{l}0.004^{*} \\
(0.002)\end{array}$ & $\begin{array}{l}-0.003 \\
(0.004)\end{array}$ \\
\hline Region FE & Yes & Yes & Yes & Yes \\
\hline Observations & 126 & 75 & 164 & 113 \\
\hline
\end{tabular}

${ }^{*} \mathrm{p}<0.1 ;{ }^{* *} \mathrm{p}<0.05 ;{ }^{* * *} \mathrm{p}<0.01$. Standard errors in parenthesis. Region-Fixed Effects include: Africa, Asia, Europe, North America, South America, and Oceania. Constant omitted. 


\section{H.2 Re-evaluating Hypothesis 2 after controlling for army and police personnel}

Table H.2: Cox proportional hazards models of estimating the effect of state repression on the time to adopting a stay-at-home order

\begin{tabular}{|c|c|c|c|c|}
\hline & \multicolumn{4}{|c|}{$\begin{array}{l}\text { Number of days since the first } \\
\text { COVID-19 case until stay-at-home order }\end{array}$} \\
\hline & $(1)$ & $(2)$ & $(3)$ & $(4)$ \\
\hline $\begin{array}{l}\mathrm{N} \text { of violent events }(\mathrm{log}) \\
\text { (per one million population) }\end{array}$ & $\begin{array}{c}0.40^{* * *} \\
(0.13)\end{array}$ & $\begin{array}{c}0.49^{* * *} \\
(0.15)\end{array}$ & & \\
\hline Human Rights Protection Score & & & $\begin{array}{c}-0.35^{* * *} \\
(0.11)\end{array}$ & $\begin{array}{c}-0.30^{* *} \\
(0.13)\end{array}$ \\
\hline Armed combat personal (\%) & $\begin{array}{c}0.02 \\
(0.28)\end{array}$ & & $\begin{array}{l}-0.03 \\
(0.27)\end{array}$ & \\
\hline $\begin{array}{l}\text { Number of police officers } \\
\text { (per } 100,000 \text { people) }\end{array}$ & & $\begin{array}{c}0.001 \\
(0.001)\end{array}$ & & $\begin{array}{l}0.0001 \\
(0.001)\end{array}$ \\
\hline Democracy score (V-Dem) & $\begin{array}{c}0.64 \\
(0.71)\end{array}$ & $\begin{array}{c}0.58 \\
(1.31)\end{array}$ & $\begin{array}{l}1.45^{* *} \\
(0.71)\end{array}$ & $\begin{array}{c}1.70 \\
(1.10)\end{array}$ \\
\hline State Capacity & $\begin{array}{l}-0.37 \\
(0.30)\end{array}$ & $\begin{array}{l}0.05 \\
(0.48)\end{array}$ & $\begin{array}{c}-0.49^{* *} \\
(0.24)\end{array}$ & $\begin{array}{l}-0.49 \\
(0.37)\end{array}$ \\
\hline $\begin{array}{l}\text { Intrastate Armed Conflict } \\
\text { (Historical) }\end{array}$ & $\begin{array}{c}0.17 \\
(0.26)\end{array}$ & $\begin{array}{c}0.19 \\
(0.38)\end{array}$ & $\begin{array}{c}0.10 \\
(0.25)\end{array}$ & $\begin{array}{c}0.21 \\
(0.34)\end{array}$ \\
\hline GDP per capita (log) & $\begin{array}{c}0.34 \\
(0.22)\end{array}$ & $\begin{array}{c}0.20 \\
(0.34)\end{array}$ & $\begin{array}{c}0.25 \\
(0.19)\end{array}$ & $\begin{array}{c}0.08 \\
(0.30)\end{array}$ \\
\hline GDP annual growth & $\begin{array}{c}0.01 \\
(0.04)\end{array}$ & $\begin{array}{l}-0.04 \\
(0.06)\end{array}$ & $\begin{array}{l}-0.01 \\
(0.03)\end{array}$ & $\begin{array}{c}0.01 \\
(0.05)\end{array}$ \\
\hline Population density & $\begin{array}{c}0.001 \\
(0.0005)\end{array}$ & $\begin{array}{c}0.002^{* *} \\
(0.001)\end{array}$ & $\begin{array}{c}0.0002 \\
(0.0002)\end{array}$ & $\begin{array}{c}0.0002 \\
(0.0001)\end{array}$ \\
\hline $\begin{array}{l}\text { Population aged } 70 \\
\text { (or older) }\end{array}$ & $\begin{array}{l}-0.09 \\
(0.07)\end{array}$ & $\begin{array}{c}-0.23^{* *} \\
(0.10)\end{array}$ & $\begin{array}{c}-0.003 \\
(0.06)\end{array}$ & $\begin{array}{l}-0.01 \\
(0.07)\end{array}$ \\
\hline Diabetes prevalence & $\begin{array}{c}0.04 \\
(0.04)\end{array}$ & $\begin{array}{l}0.10 \\
(0.07)\end{array}$ & $\begin{array}{l}0.08^{* *} \\
(0.03)\end{array}$ & $\begin{array}{c}0.15^{* * *} \\
(0.05)\end{array}$ \\
\hline Cardiovascular death rate & $\begin{array}{l}0.002^{*} \\
(0.001)\end{array}$ & $\begin{array}{c}0.01^{* *} \\
(0.003)\end{array}$ & $\begin{array}{c}0.001 \\
(0.001)\end{array}$ & $\begin{array}{c}-0.0003 \\
(0.002)\end{array}$ \\
\hline Region FE & Yes & Yes & Yes & Yes \\
\hline Observations & 126 & 75 & 164 & 113 \\
\hline
\end{tabular}

${ }^{*} \mathrm{p}<0.1 ;{ }^{* *} \mathrm{p}<0.05 ;{ }^{* * *} \mathrm{p}<0.01$. Standard errors in parenthesis. Region-Fixed Effects include: Africa, Asia, Europe, North America, South America, and Oceania. 


\section{H.3 Re-evaluating Hypothesis 3 after controlling for army and police personnel}

Table H.3: OLS regressions on the effect of repression on the length of stay-at-home orders

\begin{tabular}{|c|c|c|c|c|}
\hline & \multirow{2}{*}{\multicolumn{4}{|c|}{$\begin{array}{c}\text { Number of days with } \\
\text { stay-at-home order in place }(\log )\end{array}$}} \\
\hline & & & & \\
\hline & (1) & (2) & $(3)$ & (4) \\
\hline $\begin{array}{l}\mathrm{N} \text { of violent events (log) } \\
\text { (per one million population) }\end{array}$ & $\begin{array}{l}0.41^{*} \\
(0.23)\end{array}$ & $\begin{array}{l}0.39^{*} \\
(0.22)\end{array}$ & & \\
\hline Human rights protection score & & & $\begin{array}{c}-0.64^{* * *} \\
(0.16)\end{array}$ & $\begin{array}{c}-0.42^{* *} \\
(0.18)\end{array}$ \\
\hline Armed combat personal (\%) & $\begin{array}{l}-0.17 \\
(0.52)\end{array}$ & & $\begin{array}{l}-0.10 \\
(0.41)\end{array}$ & \\
\hline $\begin{array}{l}\text { Number of police officers } \\
\text { (per } 100,000 \text { people) }\end{array}$ & & $\begin{array}{c}-0.0003 \\
(0.001)\end{array}$ & & $\begin{array}{l}-0.001 \\
(0.001)\end{array}$ \\
\hline Democracy score (V-Dem) & $\begin{array}{c}0.93 \\
(1.26)\end{array}$ & $\begin{array}{c}1.02 \\
(1.90)\end{array}$ & $\begin{array}{l}2.73^{* *} \\
(1.07)\end{array}$ & $\begin{array}{l}2.69^{*} \\
(1.42)\end{array}$ \\
\hline State capacity & $\begin{array}{l}-0.11 \\
(0.46)\end{array}$ & $\begin{array}{l}-0.38 \\
(0.70)\end{array}$ & $\begin{array}{l}-0.43 \\
(0.35)\end{array}$ & $\begin{array}{c}-0.82^{*} \\
(0.48)\end{array}$ \\
\hline $\begin{array}{l}\text { Intrastate armed conflict } \\
\text { (Historical) }\end{array}$ & $\begin{array}{c}0.62 \\
(0.45)\end{array}$ & $\begin{array}{c}0.75 \\
(0.63)\end{array}$ & $\begin{array}{c}0.47 \\
(0.39)\end{array}$ & $\begin{array}{c}0.77 \\
(0.49)\end{array}$ \\
\hline GDP per capita (log) & $\begin{array}{c}0.45 \\
(0.44)\end{array}$ & $\begin{array}{c}0.77 \\
(0.62)\end{array}$ & $\begin{array}{l}0.61^{*} \\
(0.32)\end{array}$ & $\begin{array}{c}0.64 \\
(0.46)\end{array}$ \\
\hline GDP annual growth & $\begin{array}{l}-0.03 \\
(0.07)\end{array}$ & $\begin{array}{l}-0.06 \\
(0.09)\end{array}$ & $\begin{array}{l}-0.05 \\
(0.06)\end{array}$ & $\begin{array}{l}-0.07 \\
(0.07)\end{array}$ \\
\hline Population density & $\begin{array}{c}0.001 \\
(0.001)\end{array}$ & $\begin{array}{c}0.002 \\
(0.001)\end{array}$ & $\begin{array}{c}0.0003 \\
(0.0004)\end{array}$ & $\begin{array}{c}0.0004 \\
(0.0005)\end{array}$ \\
\hline $\begin{array}{l}\text { Population aged } 70 \\
\text { (or older) }\end{array}$ & $\begin{array}{c}-0.23^{* * *} \\
(0.08)\end{array}$ & $\begin{array}{c}-0.33^{*} \\
(0.17)\end{array}$ & $\begin{array}{l}-0.04 \\
(0.05)\end{array}$ & $\begin{array}{l}-0.06 \\
(0.06)\end{array}$ \\
\hline Diabetes prevalence & $\begin{array}{c}0.07 \\
(0.07)\end{array}$ & $\begin{array}{c}0.16 \\
(0.11)\end{array}$ & $\begin{array}{l}0.10^{* *} \\
(0.05)\end{array}$ & $\begin{array}{l}0.12^{* *} \\
(0.06)\end{array}$ \\
\hline Cardiovascular death rate & $\begin{array}{l}0.003^{*} \\
(0.002)\end{array}$ & $\begin{array}{c}0.01 \\
(0.003)\end{array}$ & $\begin{array}{c}0.003 \\
(0.002)\end{array}$ & $\begin{array}{c}0.001 \\
(0.002)\end{array}$ \\
\hline Region FE & Yes & Yes & Yes & Yes \\
\hline Observations & 126 & 75 & 164 & 113 \\
\hline
\end{tabular}

${ }^{*} \mathrm{p}<0.1 ;{ }^{* *} \mathrm{p}<0.05 ;{ }^{* * *} \mathrm{p}<0.01$. Standard errors in parenthesis. Region-Fixed Effects include: Africa, Asia, Europe, North America, South America, and Oceania. Constant omitted. 


\section{Robustness to Trust in the Government}

Some readers could believe that governments who have recently engaged in violence against civilians or who score worse on the protection of human rights scores are less likely to be trusted in their pandemic recommendations, necessitating lockdown as an attempt to implement self-protective policy. We empirically evaluate this argument in this Online Appendix.

First, we build a measure that captures the percentage of respondents who reported trusting the government "a great deal" or "quite a lot" obtained from waves 5 and 6 of the WVS (WVS 2018) and the 2018 wave of the Latin Barometer. Computed based on item $E 069_{1} 1$, which asks respondents to self-rate their degree of confidence in the central government: $1=$ a great deal; $2=$ quite a lot; $3=$ not very much; $4=$ none at all. This measure is standardized with a mean of 0 and a sd of 1 . This measure includes only countries sampled since 2009. Of the 135 countries in our ACLED sample, we have been able to find a measure of trust in government from these survey sources for 56 countries. Of the 182 countries in the entire sample, we have been able to find a measure of trust in government from these survey sources for 69 countries. Due to the massive missingness, we have decided not to add this variable in our main models. However, we have developed a strategy to evaluate whether this would constitute a significant confounder in our models.

Figure I.1 shows that trust in government is negatively correlated with the number of violent events against civilians, although not with country's human rights scores among the countries in this subsample of 56 and 69 countries, respectively. The existence of this correlation leads us to believe that trust in government could constitute a potential confounder.

To evaluate the impact of this confounder, we perform multiple imputation to impute values in the trust in government for those countries with missing data. 5 complete datasets are generated. Then, we re-estimate our models, using both number of events and human rights scores as dependent variables, adding the imputed values of the trust in government as a control in the models. The online appendix reports 5 different models (one model 
Figure I.1: Trust in government, state repression, and human rights score

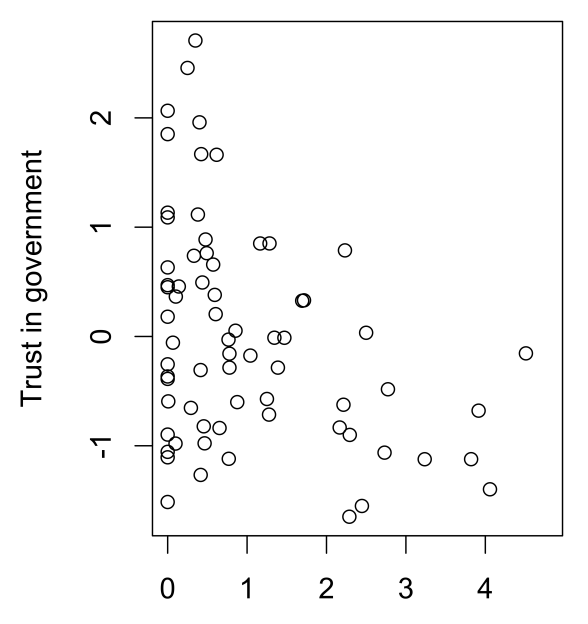

Number of violent events per capita (log)

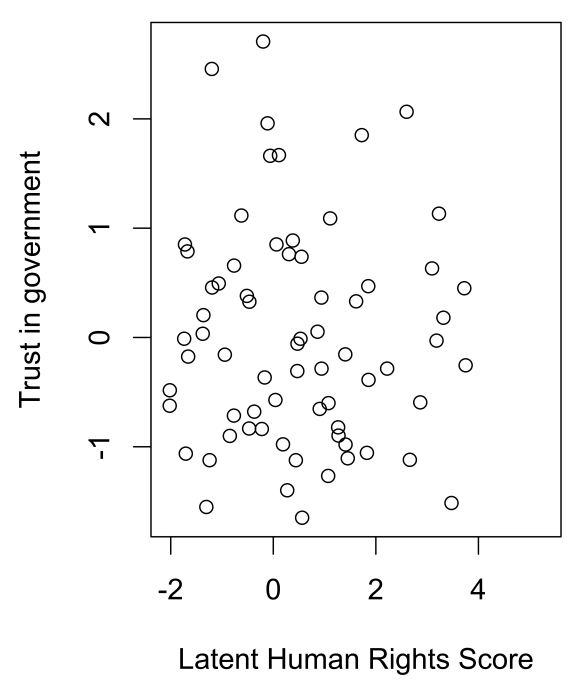

for each imputed trust in government variable). The results from this exercise reveals that our main predictor, either number of violent events per million population or human rights scores, significantly predicts adoption, timing, and length of stay-at-home orders even after controlling for trust in the government. Therefore, we conclude that it is unlikely that trust in the government would be a relevant confounder for our main estimates.

- For a re-evaluation of Hypothesis 1, see Appendix I.1.

- For a re-evaluation of Hypothesis 2, see Appendix I.2.

- For a re-evaluation of Hypothesis 3, see Appendix I.3. 
I.1 Re-evaluating Hypothesis 1 after controlling for trust in the government 
Table I.1: Logistic regressions on the effect of recent state repression on adopting stay-athome orders (controlling for trust in government)

\begin{tabular}{|c|c|c|c|c|c|c|c|c|c|c|}
\hline & \multicolumn{8}{|c|}{ Adoption of a stay-at-home order } & \multirow[b]{2}{*}{$(9)$} & \multirow[b]{2}{*}{$(10)$} \\
\hline & $(1)$ & $(2)$ & $(3)$ & $(4)$ & $(5)$ & $(6)$ & $(7)$ & $(8)$ & & \\
\hline $\begin{array}{l}\mathrm{N} \text { of violent events }(\log ) \\
\text { (per one million population) }\end{array}$ & $\begin{array}{l}0.65^{* *} \\
(0.31)\end{array}$ & $\begin{array}{l}0.64^{* *} \\
(0.30)\end{array}$ & $\begin{array}{c}0.39 \\
(0.33)\end{array}$ & $\begin{array}{l}0.68^{* *} \\
(0.31)\end{array}$ & $\begin{array}{l}0.65^{* *} \\
(0.31)\end{array}$ & & & & & \\
\hline Human Rights Protection Score & & & & & & $\begin{array}{c}-0.74^{* * *} \\
\quad(0.24)\end{array}$ & $\begin{array}{c}-0.71^{* * *} \\
(0.22)\end{array}$ & $\begin{array}{c}-0.63^{* * *} \\
(0.23)\end{array}$ & $\begin{array}{c}-0.70^{* * * *} \\
(0.22)\end{array}$ & $\begin{array}{c}-0.73^{* * *} \\
(0.23)\end{array}$ \\
\hline $\begin{array}{l}\text { Trust in government } \\
\text { (imputed 1) }\end{array}$ & $\begin{array}{c}-0.97^{* *} \\
(0.40)\end{array}$ & & & & & $\begin{array}{c}-0.85^{* * *} \\
(0.31)\end{array}$ & & & & \\
\hline $\begin{array}{l}\text { Trust in government } \\
\text { (imputed 2) }\end{array}$ & & $\begin{array}{c}0.05 \\
(0.36)\end{array}$ & & & & & $\begin{array}{c}0.05 \\
(0.29)\end{array}$ & & & \\
\hline $\begin{array}{l}\text { Trust in government } \\
\text { (imputed } 3 \text { ) }\end{array}$ & & & $\begin{array}{c}-0.85^{* * *} \\
(0.30)\end{array}$ & & & & & $\begin{array}{c}-0.62^{* * *} \\
(0.22)\end{array}$ & & \\
\hline $\begin{array}{l}\text { Trust in government } \\
\text { (imputed 4) }\end{array}$ & & & & $\begin{array}{l}0.24 \\
(0.36)\end{array}$ & & & & & $\begin{array}{l}-0.38 \\
(0.30)\end{array}$ & \\
\hline $\begin{array}{l}\text { Trust in government } \\
\text { (imputed 5) }\end{array}$ & & & & & $\begin{array}{l}-0.45 \\
(0.37)\end{array}$ & & & & & $\begin{array}{l}-0.42 \\
(0.29)\end{array}$ \\
\hline Democracy score (V-Dem) & $\begin{array}{l}-0.50 \\
(1.65)\end{array}$ & $\begin{array}{c}1.49 \\
(1.63)\end{array}$ & $\begin{array}{c}0.11 \\
(1.54)\end{array}$ & $\begin{array}{l}1.90 \\
(1.64)\end{array}$ & $\begin{array}{c}0.84 \\
(1.52)\end{array}$ & $\begin{array}{c}1.86 \\
(1.48)\end{array}$ & $\begin{array}{l}3.48^{* *} \\
(1.58)\end{array}$ & $\begin{array}{l}2.49^{*} \\
(1.45)\end{array}$ & $\begin{array}{l}2.58^{*} \\
(1.50)\end{array}$ & $\begin{array}{l}2.88^{* *} \\
(1.43)\end{array}$ \\
\hline State Capacity & $\begin{array}{c}0.93 \\
(0.70)\end{array}$ & $\begin{array}{c}0.08 \\
(0.64)\end{array}$ & $\begin{array}{c}0.68 \\
(0.66)\end{array}$ & $\begin{array}{l}-0.04 \\
(0.63)\end{array}$ & $\begin{array}{c}0.62 \\
(0.73)\end{array}$ & $\begin{array}{c}0.74 \\
(0.57)\end{array}$ & $\begin{array}{l}-0.13 \\
(0.53)\end{array}$ & $\begin{array}{c}0.35 \\
(0.51)\end{array}$ & $\begin{array}{c}0.22 \\
(0.54)\end{array}$ & $\begin{array}{c}0.37 \\
(0.58)\end{array}$ \\
\hline $\begin{array}{l}\text { Intrastate Armed Conflict } \\
\text { (Historical) }\end{array}$ & $\begin{array}{c}0.48 \\
(0.55)\end{array}$ & $\begin{array}{c}0.92 \\
(0.60)\end{array}$ & $\begin{array}{c}0.55 \\
(0.55)\end{array}$ & $\begin{array}{l}0.93^{*} \\
(0.52)\end{array}$ & $\begin{array}{l}0.89^{*} \\
(0.52)\end{array}$ & $\begin{array}{c}0.49 \\
(0.49)\end{array}$ & $\begin{array}{c}0.75 \\
(0.50)\end{array}$ & $\begin{array}{c}0.44 \\
(0.49)\end{array}$ & $\begin{array}{c}0.71 \\
(0.47)\end{array}$ & $\begin{array}{c}0.72 \\
(0.47)\end{array}$ \\
\hline GDP per capita (log) & $\begin{array}{l}0.79^{*} \\
(0.47)\end{array}$ & $\begin{array}{c}0.68 \\
(0.46)\end{array}$ & $\begin{array}{c}0.65 \\
(0.47)\end{array}$ & $\begin{array}{c}0.68 \\
(0.46)\end{array}$ & $\begin{array}{c}0.65 \\
(0.45)\end{array}$ & $\begin{array}{c}0.39 \\
(0.38)\end{array}$ & $\begin{array}{c}0.34 \\
(0.38)\end{array}$ & $\begin{array}{c}0.37 \\
(0.39)\end{array}$ & $\begin{array}{c}0.40 \\
(0.38)\end{array}$ & $\begin{array}{c}0.37 \\
(0.38)\end{array}$ \\
\hline GDP Annual Growth & $\begin{array}{c}0.01 \\
(0.08)\end{array}$ & $\begin{array}{c}0.01 \\
(0.08)\end{array}$ & $\begin{array}{c}0.03 \\
(0.08)\end{array}$ & $\begin{array}{l}0.003 \\
(0.08)\end{array}$ & $\begin{array}{l}-0.01 \\
(0.08)\end{array}$ & $\begin{array}{l}-0.09 \\
(0.07)\end{array}$ & $\begin{array}{l}-0.07 \\
(0.07)\end{array}$ & $\begin{array}{l}-0.05 \\
(0.07)\end{array}$ & $\begin{array}{l}-0.07 \\
(0.07)\end{array}$ & $\begin{array}{l}-0.09 \\
(0.07)\end{array}$ \\
\hline Population Density ('000) & $\begin{array}{c}3.02 \\
(1.96)\end{array}$ & $\begin{array}{c}1.94 \\
(1.70)\end{array}$ & $\begin{array}{l}1.87 \\
(1.72)\end{array}$ & $\begin{array}{l}2.19 \\
(1.71)\end{array}$ & $\begin{array}{l}1.64 \\
(1.64)\end{array}$ & $\begin{array}{c}0.36 \\
(0.45)\end{array}$ & $\begin{array}{c}0.36 \\
(0.38)\end{array}$ & $\begin{array}{c}0.34 \\
(0.38)\end{array}$ & $\begin{array}{c}0.33 \\
(0.38)\end{array}$ & $\begin{array}{c}0.32 \\
(0.36)\end{array}$ \\
\hline $\begin{array}{l}\text { Population aged } 70 \\
\text { or older (percentage) }\end{array}$ & $\begin{array}{c}-0.41^{* * *} \\
(0.15)\end{array}$ & $\begin{array}{c}-0.32^{* *} \\
(0.14)\end{array}$ & $\begin{array}{c}-0.45^{* * *} \\
(0.15)\end{array}$ & $\begin{array}{c}-0.31^{* *} \\
(0.14)\end{array}$ & $\begin{array}{c}-0.37^{* *} \\
(0.15)\end{array}$ & $\begin{array}{c}-0.22^{* *} \\
(0.11)\end{array}$ & $\begin{array}{l}-0.13 \\
(0.11)\end{array}$ & $\begin{array}{c}-0.25^{* *} \\
(0.12)\end{array}$ & $\begin{array}{l}-0.17 \\
(0.11)\end{array}$ & $\begin{array}{c}-0.20^{*} \\
(0.11)\end{array}$ \\
\hline Diabetes prevalence & $\begin{array}{c}0.18 \\
(0.11)\end{array}$ & $\begin{array}{l}0.19^{*} \\
(0.11)\end{array}$ & $\begin{array}{l}0.20^{*} \\
(0.12)\end{array}$ & $\begin{array}{l}0.18^{*} \\
(0.11)\end{array}$ & $\begin{array}{l}0.20^{*} \\
(0.11)\end{array}$ & $\begin{array}{l}0.22^{* *} \\
(0.09)\end{array}$ & $\begin{array}{c}0.26^{* * *} \\
(0.09)\end{array}$ & $\begin{array}{c}0.25^{* * *} \\
(0.09)\end{array}$ & $\begin{array}{c}0.26^{* * *} \\
(0.09)\end{array}$ & $\begin{array}{c}0.25^{* * *} \\
(0.09)\end{array}$ \\
\hline Cardiovascular death rate & $\begin{array}{l}0.01^{* * *} \\
(0.003)\end{array}$ & $\begin{array}{c}0.01^{* *} \\
(0.003)\end{array}$ & $\begin{array}{l}0.01^{* * *} \\
(0.003)\end{array}$ & $\begin{array}{c}0.01^{* *} \\
(0.003)\end{array}$ & $\begin{array}{l}0.01^{* * *} \\
(0.003)\end{array}$ & $\begin{array}{c}0.01^{* *} \\
(0.002)\end{array}$ & $\begin{array}{l}0.004^{*} \\
(0.002)\end{array}$ & $\begin{array}{c}0.01^{* *} \\
(0.002)\end{array}$ & $\begin{array}{c}0.01^{* *} \\
(0.002)\end{array}$ & $\begin{array}{c}0.01^{* *} \\
(0.003)\end{array}$ \\
\hline Constant & $\begin{array}{c}-8.29^{*} \\
(4.50)\end{array}$ & $\begin{array}{c}-9.34^{* *} \\
(4.46)\end{array}$ & $\begin{array}{c}-7.69^{*} \\
(4.55)\end{array}$ & $\begin{array}{c}-9.61^{* *} \\
(4.43)\end{array}$ & $\begin{array}{c}-8.67^{* *} \\
(4.38)\end{array}$ & $\begin{array}{l}-4.80 \\
(3.62)\end{array}$ & $\begin{array}{c}-6.42^{*} \\
(3.61)\end{array}$ & $\begin{array}{l}-5.61 \\
(3.66)\end{array}$ & $\begin{array}{c}-6.33^{*} \\
(3.57)\end{array}$ & $\begin{array}{c}-6.21^{*} \\
(3.56)\end{array}$ \\
\hline Region FE & Yes & Yes & Yes & Yes & Yes & Yes & Yes & Yes & Yes & Yes \\
\hline Observations & 135 & 135 & 135 & 135 & 135 & 178 & 178 & 178 & 178 & 178 \\
\hline
\end{tabular}

${ }^{*} \mathrm{p}<0.1 ;{ }^{* *} \mathrm{p}<0.05 ;{ }^{* * *} \mathrm{p}<0.01$. Standard errors in parenthesis. Region-Fixed Effects include: Africa, Asia, Europe, North America, South America, and Oceania. 
I.2 Re-evaluating Hypothesis 2 after controlling for trust in the government 
Table I.2: Cox proportional hazards models of estimating the effect of state repression on the time to adopting a stay-at-home order (controlling for trust in government)

\begin{tabular}{|c|c|c|c|c|c|c|c|c|c|c|}
\hline & \multicolumn{10}{|c|}{ Number of days since the first COVID-19 case until stay-at-home order } \\
\hline & (1) & $(2)$ & $(3)$ & $(4)$ & $(5)$ & (6) & (7) & (8) & (9) & $(10)$ \\
\hline $\begin{array}{l}\mathrm{N} \text { of violent events }(\mathrm{log}) \\
\text { (per one million population) }\end{array}$ & $\begin{array}{c}0.50^{* * *} \\
(0.13)\end{array}$ & $\begin{array}{c}0.47^{* * *} \\
(0.12)\end{array}$ & $\begin{array}{c}0.36^{* * *} \\
(0.13)\end{array}$ & $\begin{array}{c}0.45^{* * *} \\
(0.12)\end{array}$ & $\begin{array}{c}0.45^{* * *} \\
(0.12)\end{array}$ & & & & & \\
\hline Human Rights Protection Score & & & & & & $\begin{array}{c}-0.27^{* *} \\
(0.11)\end{array}$ & $\begin{array}{c}-0.29^{* * *} \\
(0.11)\end{array}$ & $\begin{array}{c}-0.21^{*} \\
(0.11)\end{array}$ & $\begin{array}{c}-0.29^{* * *} \\
(0.11)\end{array}$ & $\begin{array}{c}-0.29^{* * *} \\
(0.11)\end{array}$ \\
\hline $\begin{array}{l}\text { Trust in government } \\
\text { (imputed } 1 \text { ) }\end{array}$ & $\begin{array}{c}-0.53^{* * *} \\
(0.19)\end{array}$ & & & & & $\begin{array}{c}-0.48^{* * *} \\
(0.17)\end{array}$ & & & & \\
\hline $\begin{array}{l}\text { Trust in government } \\
\text { (imputed 2) }\end{array}$ & & $\begin{array}{l}-0.21 \\
(0.18)\end{array}$ & & & & & $\begin{array}{l}-0.09 \\
(0.15)\end{array}$ & & & \\
\hline $\begin{array}{l}\text { Trust in government } \\
\text { (imputed } 3 \text { ) }\end{array}$ & & & $\begin{array}{c}-0.40^{* * * *} \\
(0.14)\end{array}$ & & & & & $\begin{array}{c}-0.42^{* * *} \\
(0.13)\end{array}$ & & \\
\hline $\begin{array}{l}\text { Trust in government } \\
\text { (imputed } 4 \text { ) }\end{array}$ & & & & $\begin{array}{l}-0.05 \\
(0.17)\end{array}$ & & & & & $\begin{array}{l}-0.23 \\
(0.16)\end{array}$ & \\
\hline $\begin{array}{l}\text { Trust in government } \\
\text { (imputed 5) }\end{array}$ & & & & & $\begin{array}{l}-0.12 \\
(0.17)\end{array}$ & & & & & $\begin{array}{l}-0.05 \\
(0.16)\end{array}$ \\
\hline Democracy score (V-Dem) & $\begin{array}{l}-0.35 \\
(0.78)\end{array}$ & $\begin{array}{c}0.30 \\
(0.77)\end{array}$ & $\begin{array}{c}0.36 \\
(0.71)\end{array}$ & $\begin{array}{c}0.62 \\
(0.74)\end{array}$ & $\begin{array}{l}0.58 \\
(0.72)\end{array}$ & $\begin{array}{l}0.68 \\
(0.75)\end{array}$ & $\begin{array}{l}1.35^{*} \\
(0.77)\end{array}$ & $\begin{array}{c}0.98 \\
(0.72)\end{array}$ & $\begin{array}{c}1.18 \\
(0.74)\end{array}$ & $\begin{array}{l}1.50^{* *} \\
(0.72)\end{array}$ \\
\hline State Capacity & $\begin{array}{c}0.11 \\
(0.35)\end{array}$ & $\begin{array}{l}-0.30 \\
(0.31)\end{array}$ & $\begin{array}{l}-0.28 \\
(0.29)\end{array}$ & $\begin{array}{l}-0.43 \\
(0.30)\end{array}$ & $\begin{array}{l}-0.36 \\
(0.32)\end{array}$ & $\begin{array}{l}-0.01 \\
(0.28)\end{array}$ & $\begin{array}{l}-0.38 \\
(0.26)\end{array}$ & $\begin{array}{l}-0.24 \\
(0.25)\end{array}$ & $\begin{array}{l}-0.28 \\
(0.26)\end{array}$ & $\begin{array}{l}-0.40 \\
(0.28)\end{array}$ \\
\hline $\begin{array}{l}\text { Intrastate Armed Conflict } \\
\text { (Historical) }\end{array}$ & $\begin{array}{l}-0.04 \\
(0.26)\end{array}$ & $\begin{array}{c}0.01 \\
(0.27)\end{array}$ & $\begin{array}{l}-0.04 \\
(0.26)\end{array}$ & $\begin{array}{c}0.12 \\
(0.26)\end{array}$ & $\begin{array}{c}0.11 \\
(0.26)\end{array}$ & $\begin{array}{l}0.03 \\
(0.25)\end{array}$ & $\begin{array}{c}0.10 \\
(0.26)\end{array}$ & $\begin{array}{l}-0.06 \\
(0.25)\end{array}$ & $\begin{array}{c}0.16 \\
(0.25)\end{array}$ & $\begin{array}{c}0.14 \\
(0.25)\end{array}$ \\
\hline GDP per capita (log) & $\begin{array}{l}0.45^{* *} \\
(0.22)\end{array}$ & $\begin{array}{l}0.45^{* *} \\
(0.21)\end{array}$ & $\begin{array}{l}0.47^{* *} \\
(0.21)\end{array}$ & $\begin{array}{l}0.43^{* *} \\
(0.21)\end{array}$ & $\begin{array}{l}0.44^{* *} \\
(0.21)\end{array}$ & $\begin{array}{c}0.21 \\
(0.20)\end{array}$ & $\begin{array}{c}0.19 \\
(0.19)\end{array}$ & $\begin{array}{c}0.22 \\
(0.19)\end{array}$ & $\begin{array}{c}0.23 \\
(0.19)\end{array}$ & $\begin{array}{c}0.20 \\
(0.19)\end{array}$ \\
\hline GDP Annual Growth & $\begin{array}{c}-0.002 \\
(0.04)\end{array}$ & $\begin{array}{c}0.01 \\
(0.04)\end{array}$ & $\begin{array}{c}0.02 \\
(0.04)\end{array}$ & $\begin{array}{c}0.01 \\
(0.04)\end{array}$ & $\begin{array}{c}0.01 \\
(0.04)\end{array}$ & $\begin{array}{l}-0.03 \\
(0.03)\end{array}$ & $\begin{array}{l}-0.02 \\
(0.03)\end{array}$ & $\begin{array}{l}-0.01 \\
(0.03)\end{array}$ & $\begin{array}{c}-0.02 \\
(0.03)\end{array}$ & $\begin{array}{l}-0.02 \\
(0.03)\end{array}$ \\
\hline Population Density ('000) & $\begin{array}{l}0.74^{*} \\
(0.44)\end{array}$ & $\begin{array}{c}0.73 \\
(0.48)\end{array}$ & $\begin{array}{c}0.69 \\
(0.49)\end{array}$ & $\begin{array}{c}0.59 \\
(0.47)\end{array}$ & $\begin{array}{c}0.58 \\
(0.48)\end{array}$ & $\begin{array}{c}0.17 \\
(0.13)\end{array}$ & $\begin{array}{c}0.18 \\
(0.14)\end{array}$ & $\begin{array}{c}0.18 \\
(0.14)\end{array}$ & $\begin{array}{c}0.18 \\
(0.14)\end{array}$ & $\begin{array}{c}0.18 \\
(0.14)\end{array}$ \\
\hline Population aged 70 & $\begin{array}{c}-0.16^{* *} \\
(0.07)\end{array}$ & $\begin{array}{c}-0.11^{*} \\
(0.07)\end{array}$ & $\begin{array}{c}-0.17^{* *} \\
(0.07)\end{array}$ & $\begin{array}{l}-0.11 \\
(0.07)\end{array}$ & $\begin{array}{c}-0.12^{*} \\
(0.07)\end{array}$ & $\begin{array}{l}-0.08 \\
(0.06)\end{array}$ & $\begin{array}{l}-0.03 \\
(0.05)\end{array}$ & $\begin{array}{l}-0.10 \\
(0.06)\end{array}$ & $\begin{array}{l}-0.05 \\
(0.06)\end{array}$ & $\begin{array}{l}-0.03 \\
(0.06)\end{array}$ \\
\hline Diabetes prevalence & $\begin{array}{l}-0.01 \\
(0.04)\end{array}$ & $\begin{array}{c}0.03 \\
(0.04)\end{array}$ & $\begin{array}{c}0.02 \\
(0.04)\end{array}$ & $\begin{array}{c}0.03 \\
(0.04)\end{array}$ & $\begin{array}{c}0.03 \\
(0.04)\end{array}$ & $\begin{array}{l}0.06^{*} \\
(0.04)\end{array}$ & $\begin{array}{c}0.09^{* * *} \\
(0.03)\end{array}$ & $\begin{array}{l}0.08^{* *} \\
(0.03)\end{array}$ & $\begin{array}{c}0.09^{* * *} \\
(0.03)\end{array}$ & $\begin{array}{c}0.09^{* * *} \\
(0.03)\end{array}$ \\
\hline Cardiovascular death rate & $\begin{array}{l}0.003^{* *} \\
(0.001)\end{array}$ & $\begin{array}{l}0.003^{* *} \\
(0.001)\end{array}$ & $\begin{array}{c}0.003^{* * *} \\
(0.001)\end{array}$ & $\begin{array}{c}0.002^{*} \\
(0.001)\end{array}$ & $\begin{array}{c}0.002^{*} \\
(0.001)\end{array}$ & $\begin{array}{c}0.002 \\
(0.001)\end{array}$ & $\begin{array}{c}0.001 \\
(0.001)\end{array}$ & $\begin{array}{c}0.002^{*} \\
(0.001)\end{array}$ & $\begin{array}{c}0.001 \\
(0.001)\end{array}$ & $\begin{array}{c}0.001 \\
(0.001)\end{array}$ \\
\hline Constant & $\begin{array}{c}-8.29^{*} \\
(4.50)\end{array}$ & $\begin{array}{c}-9.34^{* *} \\
(4.46)\end{array}$ & $\begin{array}{c}-7.69^{*} \\
(4.55)\end{array}$ & $\begin{array}{c}-9.61^{* *} \\
(4.43)\end{array}$ & $\begin{array}{c}-8.67^{* *} \\
(4.38)\end{array}$ & $\begin{array}{l}-4.80 \\
(3.62)\end{array}$ & $\begin{array}{c}-6.42^{*} \\
(3.61)\end{array}$ & $\begin{array}{l}-5.61 \\
(3.66)\end{array}$ & $\begin{array}{c}-6.33^{*} \\
(3.57)\end{array}$ & $\begin{array}{c}-6.21^{*} \\
(3.56)\end{array}$ \\
\hline Region FE & Yes & Yes & Yes & Yes & Yes & Yes & Yes & Yes & Yes & Yes \\
\hline Observations & 135 & 135 & 135 & 135 & 135 & 178 & 178 & 178 & 178 & 178 \\
\hline
\end{tabular}

${ }^{*} \mathrm{p}<0.1 ;{ }^{* *} \mathrm{p}<0.05 ;{ }^{* * *} \mathrm{p}<0.01$. Standard errors in parenthesis. Region-Fixed Effects include: Africa, Asia, Europe, North America, South America, and Oceania. 
I.3 Re-evaluating Hypothesis 3 after controlling for trust in the government 
Table I.3: OLS regressions on the effect of repression on the length of stay-at-home orders (controlling for trust in government)

\begin{tabular}{|c|c|c|c|c|c|c|c|c|c|c|}
\hline & \multicolumn{10}{|c|}{ Number of days with stay-at-home order in place (log) } \\
\hline & $(1)$ & $(2)$ & $(3)$ & $(4)$ & $(5)$ & $(6)$ & $(7)$ & $(8)$ & $(9)$ & $(10)$ \\
\hline $\begin{array}{l}\mathrm{N} \text { of violent events (log) } \\
\text { (per one million population) }\end{array}$ & $\begin{array}{c}0.44^{* * *} \\
(0.17)\end{array}$ & $\begin{array}{l}0.47^{* *} \\
(0.19)\end{array}$ & $\begin{array}{c}0.23 \\
(0.19)\end{array}$ & $\begin{array}{l}0.47^{* *} \\
(0.20)\end{array}$ & $\begin{array}{l}0.46^{* *} \\
(0.20)\end{array}$ & & & & & \\
\hline Human Rights Protection Score & & & & & & $\begin{array}{c}-0.49^{* * *} \\
(0.15)\end{array}$ & $\begin{array}{c}-0.52^{* * *} \\
(0.16)\end{array}$ & $\begin{array}{c}-0.41^{* * *} \\
\quad(0.16)\end{array}$ & $\begin{array}{c}-0.51^{* * *} \\
(0.16)\end{array}$ & $\begin{array}{c}-0.52^{* * *} \\
(0.15)\end{array}$ \\
\hline $\begin{array}{l}\text { Trust in government } \\
\text { (imputed 1) }\end{array}$ & $\begin{array}{c}-0.72^{* *} \\
(0.30)\end{array}$ & & & & & $\begin{array}{c}-0.72^{* * *} \\
(0.21)\end{array}$ & & & & \\
\hline $\begin{array}{l}\text { Trust in government } \\
\text { (imputed 2) }\end{array}$ & & $\begin{array}{l}-0.08 \\
(0.28)\end{array}$ & & & & & $\begin{array}{l}-0.07 \\
(0.24)\end{array}$ & & & \\
\hline $\begin{array}{l}\text { Trust in government } \\
\text { (imputed 3) }\end{array}$ & & & $\begin{array}{c}-0.80^{* * *} \\
(0.21)\end{array}$ & & & & & $\begin{array}{c}-0.61^{* * *} \\
(0.19)\end{array}$ & & \\
\hline $\begin{array}{l}\text { Trust in government } \\
\text { (imputed } 4 \text { ) }\end{array}$ & & & & $\begin{array}{l}-0.03 \\
(0.34)\end{array}$ & & & & & $\begin{array}{l}-0.34 \\
(0.24)\end{array}$ & \\
\hline $\begin{array}{l}\text { Trust in government } \\
\text { (imputed 5) }\end{array}$ & & & & & $\begin{array}{l}-0.37 \\
(0.32)\end{array}$ & & & & & $\begin{array}{l}-0.28 \\
(0.24)\end{array}$ \\
\hline Democracy score (V-Dem) & $\begin{array}{l}-0.21 \\
(1.27)\end{array}$ & $\begin{array}{c}0.86 \\
(1.27)\end{array}$ & $\begin{array}{c}0.02 \\
(1.24)\end{array}$ & $\begin{array}{c}0.97 \\
(1.39)\end{array}$ & $\begin{array}{c}0.56 \\
(1.33)\end{array}$ & $\begin{array}{c}0.98 \\
(1.16)\end{array}$ & $\begin{array}{l}2.42^{* *} \\
(1.19)\end{array}$ & $\begin{array}{c}1.49 \\
(1.03)\end{array}$ & $\begin{array}{l}1.79 \\
(1.24)\end{array}$ & $\begin{array}{l}2.20^{* *} \\
(1.11)\end{array}$ \\
\hline State Capacity & $\begin{array}{c}0.52 \\
(0.44)\end{array}$ & $\begin{array}{l}-0.06 \\
(0.43)\end{array}$ & $\begin{array}{c}0.32 \\
(0.42)\end{array}$ & $\begin{array}{l}-0.10 \\
(0.48)\end{array}$ & $\begin{array}{c}0.22 \\
(0.51)\end{array}$ & $\begin{array}{c}0.49 \\
(0.39)\end{array}$ & $\begin{array}{l}-0.20 \\
(0.37)\end{array}$ & $\begin{array}{c}0.20 \\
(0.33)\end{array}$ & $\begin{array}{c}0.05 \\
(0.40)\end{array}$ & $\begin{array}{c}0.03 \\
(0.42)\end{array}$ \\
\hline $\begin{array}{l}\text { Intrastate Armed Conflict } \\
\text { (Historical) }\end{array}$ & $\begin{array}{c}0.37 \\
(0.41)\end{array}$ & $\begin{array}{c}0.53 \\
(0.44)\end{array}$ & $\begin{array}{c}0.29 \\
(0.40)\end{array}$ & $\begin{array}{c}0.58 \\
(0.42)\end{array}$ & $\begin{array}{c}0.56 \\
(0.42)\end{array}$ & $\begin{array}{c}0.41 \\
(0.35)\end{array}$ & $\begin{array}{c}0.56 \\
(0.38)\end{array}$ & $\begin{array}{c}0.38 \\
(0.35)\end{array}$ & $\begin{array}{c}0.60 \\
(0.38)\end{array}$ & $\begin{array}{c}0.58 \\
(0.37)\end{array}$ \\
\hline GDP per capita (log) & $\begin{array}{c}0.50 \\
(0.35)\end{array}$ & $\begin{array}{c}0.47 \\
(0.37)\end{array}$ & $\begin{array}{c}0.49 \\
(0.34)\end{array}$ & $\begin{array}{c}0.47 \\
(0.37)\end{array}$ & $\begin{array}{c}0.47 \\
(0.36)\end{array}$ & $\begin{array}{c}0.40 \\
(0.27)\end{array}$ & $\begin{array}{c}0.42 \\
(0.28)\end{array}$ & $\begin{array}{l}0.48^{*} \\
(0.27)\end{array}$ & $\begin{array}{l}0.48^{*} \\
(0.28)\end{array}$ & $\begin{array}{c}0.44 \\
(0.28)\end{array}$ \\
\hline GDP Annual Growth & $\begin{array}{l}-0.03 \\
(0.06)\end{array}$ & $\begin{array}{l}-0.03 \\
(0.06)\end{array}$ & $\begin{array}{l}0.001 \\
(0.06)\end{array}$ & $\begin{array}{l}-0.03 \\
(0.06)\end{array}$ & $\begin{array}{l}-0.04 \\
(0.06)\end{array}$ & $\begin{array}{l}-0.09 \\
(0.05)\end{array}$ & $\begin{array}{l}-0.08 \\
(0.05)\end{array}$ & $\begin{array}{l}-0.05 \\
(0.05)\end{array}$ & $\begin{array}{l}-0.07 \\
(0.05)\end{array}$ & $\begin{array}{l}-0.09 \\
(0.05)\end{array}$ \\
\hline Population Density ('000) & $\begin{array}{c}0.75 \\
(1.26)\end{array}$ & $\begin{array}{c}0.62 \\
(0.94)\end{array}$ & $\begin{array}{c}0.65 \\
(0.81)\end{array}$ & $\begin{array}{c}0.58 \\
(0.97)\end{array}$ & $\begin{array}{c}0.48 \\
(0.86)\end{array}$ & $\begin{array}{c}0.25 \\
(0.35)\end{array}$ & $\begin{array}{c}0.26 \\
(0.54)\end{array}$ & $\begin{array}{c}0.26 \\
(0.47)\end{array}$ & $\begin{array}{c}0.24 \\
(0.53)\end{array}$ & $\begin{array}{c}0.24 \\
(0.61)\end{array}$ \\
\hline $\begin{array}{l}\text { Population aged } 70 \\
\text { (or older) }\end{array}$ & $\begin{array}{c}-0.33^{* * *} \\
(0.09)\end{array}$ & $\begin{array}{c}-0.25^{* * *} \\
(0.08)\end{array}$ & $\begin{array}{c}-0.36^{* * *} \\
(0.08)\end{array}$ & $\begin{array}{c}-0.25^{* * *} \\
(0.09)\end{array}$ & $\begin{array}{c}-0.29^{* * *} \\
(0.09)\end{array}$ & $\begin{array}{c}-0.16^{* * *} \\
(0.06)\end{array}$ & $\begin{array}{l}-0.06 \\
(0.06)\end{array}$ & $\begin{array}{c}-0.16^{* * *} \\
(0.06)\end{array}$ & $\begin{array}{l}-0.09 \\
(0.06)\end{array}$ & $\begin{array}{l}-0.09 \\
(0.06)\end{array}$ \\
\hline Diabetes prevalence & $\begin{array}{c}0.04 \\
(0.07)\end{array}$ & $\begin{array}{c}0.07 \\
(0.07)\end{array}$ & $\begin{array}{c}0.05 \\
(0.07)\end{array}$ & $\begin{array}{c}0.07 \\
(0.07)\end{array}$ & $\begin{array}{c}0.07 \\
(0.07)\end{array}$ & $\begin{array}{c}0.06 \\
(0.05)\end{array}$ & $\begin{array}{l}0.11^{* *} \\
(0.05)\end{array}$ & $\begin{array}{l}0.09^{* *} \\
(0.04)\end{array}$ & $\begin{array}{l}0.10^{* *} \\
(0.05)\end{array}$ & $\begin{array}{l}0.11^{* *} \\
(0.05)\end{array}$ \\
\hline Cardiovascular death rate & $\begin{array}{l}0.005^{* *} \\
(0.002)\end{array}$ & $\begin{array}{l}0.004^{*} \\
(0.002)\end{array}$ & $\begin{array}{c}0.005^{* * *} \\
(0.002)\end{array}$ & $\begin{array}{l}0.004^{*} \\
(0.002)\end{array}$ & $\begin{array}{l}0.004^{* *} \\
(0.002)\end{array}$ & $\begin{array}{l}0.004^{* *} \\
(0.002)\end{array}$ & $\begin{array}{l}0.003^{*} \\
(0.002)\end{array}$ & $\begin{array}{c}0.004^{* * *} \\
(0.002)\end{array}$ & $\begin{array}{l}0.004^{* *} \\
(0.002)\end{array}$ & $\begin{array}{l}0.004^{* *} \\
(0.002)\end{array}$ \\
\hline Constant & $\begin{array}{l}-2.10 \\
(3.27)\end{array}$ & $\begin{array}{l}-3.27 \\
(3.38)\end{array}$ & $\begin{array}{l}-2.28 \\
(3.33)\end{array}$ & $\begin{array}{l}-3.35 \\
(3.44)\end{array}$ & $\begin{array}{l}-3.09 \\
(3.45)\end{array}$ & $\begin{array}{l}-1.52 \\
(2.76)\end{array}$ & $\begin{array}{l}-3.39 \\
(2.76)\end{array}$ & $\begin{array}{l}-2.94 \\
(2.71)\end{array}$ & $\begin{array}{l}-3.50 \\
(2.82)\end{array}$ & $\begin{array}{l}-3.45 \\
(2.82)\end{array}$ \\
\hline Region FE & Yes & Yes & Yes & Yes & Yes & Yes & Yes & Yes & Yes & Yes \\
\hline Observations & 135 & 135 & 135 & 135 & 135 & 178 & 178 & 178 & 178 & 178 \\
\hline
\end{tabular}

${ }^{*} \mathrm{p}<0.1 ;{ }^{* *} \mathrm{p}<0.05 ;{ }^{* * *} \mathrm{p}<0.01$. Standard errors in parenthesis. Region-Fixed Effects include: Africa, Asia, Europe,

North America, South America, and Oceania. 